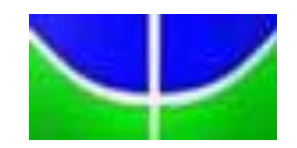

Universidade de Brasília - UNB

Faculdade de Economia, Administração, Contabilidade e Ciência da Informação - FACE Departamento de Ciência da Informação e Documentação - CID

\title{
Projeto Conte esta História - Mala do Livro: ponto de partida para a cultura
}




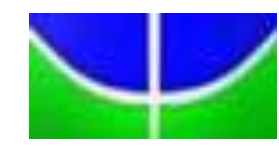

Universidade de Brasília - UNB

Faculdade de Economia, Administração, Contabilidade e Ciência da Informação - FACE

Departamento de Ciência da Informação e Documentação - CID

\section{Projeto Conte esta História - Mala do Livro: ponto de partida para a cultura}

Monografia apresentada ao Departamento de Ciência da Informação e Documentação como requisito parcial para obtenção do grau de bacharel em Biblioteconomia.

Orientadora: Prof. Dra. Maria Alice Guimarães Borges 
Power, Gabriela Fonseca.

Projeto Conte esta História - Mala do Livro: uma análise. / Gabriela Fonseca Power; Liana Barquette Vasconcelos, 2009.

83 f. : il., color. ; $30 \mathrm{~cm}$.

Monografia (graduação) - Universidade de Brasília, Departamento de Ciência da Informação e Documentação, 2009.

Orientação: $\operatorname{Prof}^{\mathrm{a}} \mathrm{Dr}^{\mathrm{a}}$ Maria Alice Guimarães Borges.

1.Biblioteca Pública. 2. Importância da Leitura. 3. Acesso à informação. 4.Planejamento de biblioteca. 5. Metrô - DF. 6. Projeto Mala do Livro. 7. Projeto Conte esta História. I. Vasconcelos, Liana Barquette. II. Borges, Maria Alice Guimarães, orient., II. Título. 


\section{RESUMO}

Esta monografia realiza uma análise do Projeto "Conte esta História - Mala do Livro". Este projeto tem como objetivo o acesso à leitura no Distrito Federal, realizado pela Secretaria de Cultura no Metrô - DF. A monografia verifica a questão do acesso à informação e a importância da leitura para o desenvolvimento da sociedade. Descreve o planejamento de bibliotecas e busca caracterizar a Biblioteca Pública e sua função social. Realiza o estudo de caso, apresentando uma descrição do "Mala do Livro" e, especificamente, do Projeto Conte esta História. A partir do levantamento de dados, como o perfil dos usuários e estatísticas do Metrô e da Secretaria de Cultura, apresenta os pontos fortes e fracos do projeto, e sugere estratégias de melhorias para um eficiente atendimento à comunidade.

Palavras-chave: Biblioteca Pública. Importância da Leitura. Acesso à Informação. Planejamento de Biblioteca. Projeto Mala do Livro/Metrô - DF. Projeto Conte esta História. 


\begin{abstract}
This monograph analyses the Project "Conte esta História - Mala do Livro." This project aims to access the reading in the Distrito Federal, conducted by the Secretaria de Cultura no Metrô - DF. The monograph notes the issue of access to information and the importance of reading to the development of society. Describes the planning of library searches and characterize the Public Library and its social function. Performs the case study, giving a description of "Mala do Livro" and, specially, the Project "Conte esta História". From the survey data, such as the profile of users and statistics of Metro and the Department of Culture, presents the strengths and weaknesses of the project, and suggests strategies for improvements to an efficient service to the community.
\end{abstract}

Key-Words: Public Library. Importance of Reading. Access to Information. Planning Library. Project Mala do Livro/Metrô - DF. Project Conte esta História. 


\section{LISTA DE FIGURAS}

Figura 1: Síntese da Dinâmica do Processo de Planejamento

Figura 2: O Planejamento nos três níveis da empresa

Figura 3: Etapas do Planejamento Estratégico e sua Implementação

Figura 4: Fases do Projeto

Figura 5: Embarque na Leitura

Figura 6: Livros \& Trilhos

Figura 7: Faixa Etária

Figura 8: Grau de Instrução

Figura 9: Renda Familiar

Figura 10: Motivo da viagem

Figura 11: Comunicação Sonora das Estações

Figura 12: Limpeza e Conservação das Estações

Figura 13: Tempo de espera na Bilheteria

Figura 14: Tempo de Viagem

Figura 15: Segurança no Sistema

Figura 16: Clareza das Informações

Figura 17: Avaliação do Serviço do Metrô - DF

Figura 18: Organograma da Diretoria de Bibliotecas

Figura 19: Baú para Doação

Figura 20: Totem de orientação para o usuário

Figura 21: Estação "Casa do Cantador"

Figura 22: Estação "Escritores de Brasília"

Figura 23: Estação "Meio Ambiente"

Figura 24: Livro em Braile

Figura 25: Usuários que conhecem o projeto

Figura 26: Gênero da amostra

Figura 27: Local onde reside

Figura 28: Faixa Etária

Figura 29: Nível de Escolaridade

Figura 30: Ocupação

Figura 31: Renda Familiar Mensal 
Figura 32: Frequenta Bibliotecas

Figura 33: Quantidade de livros lidos por ano

Figura 34: Retirou livros do projeto

Figura 35: Quantidade de Livros que retirou do Projeto

Figura 36: Dificuldade ao usar o Projeto 


\section{LISTA DE TABELAS}

Tabela 1: Estatísticas de uso do Conte esta História 2008

Tabela 2: Estatísticas de uso do Conte esta História 2009 


\section{SUMÁRIO}

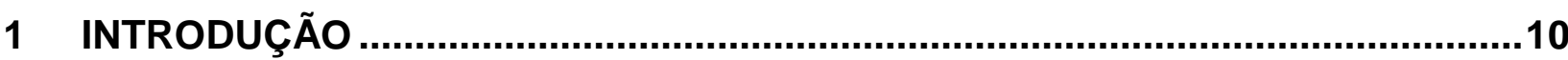

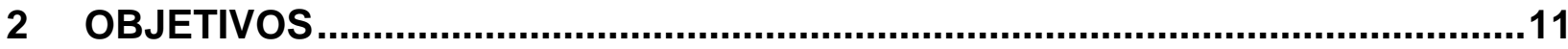

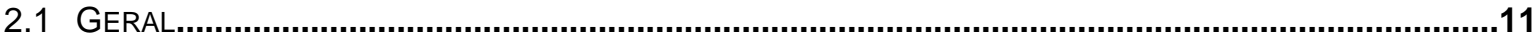

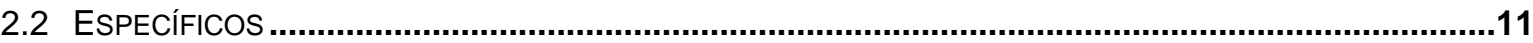

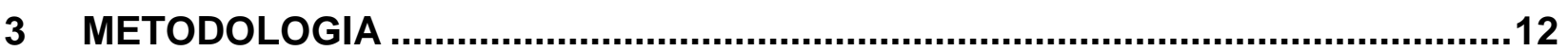

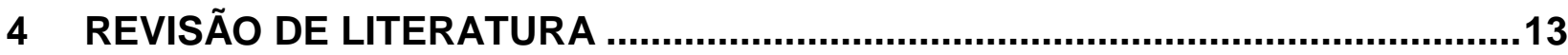

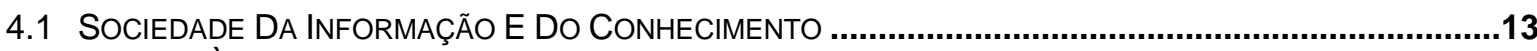

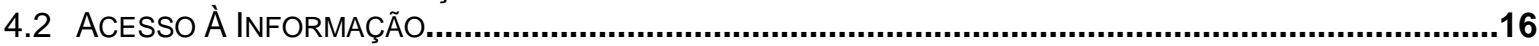

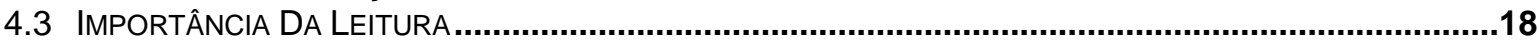

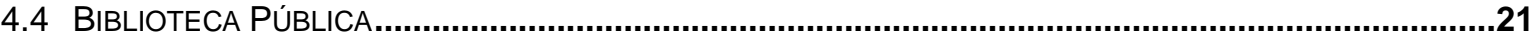

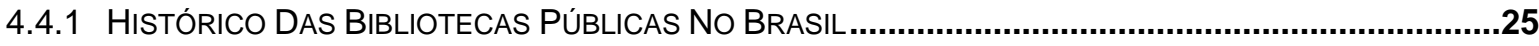

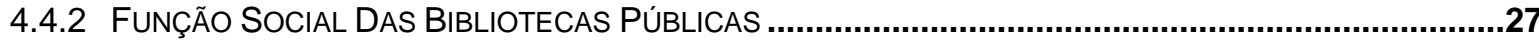

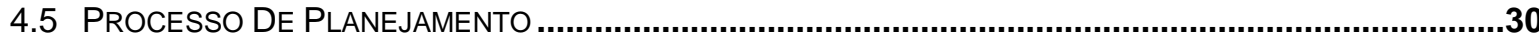

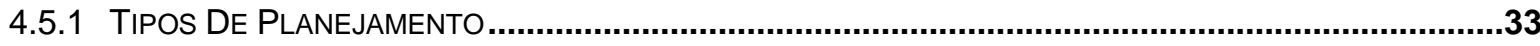

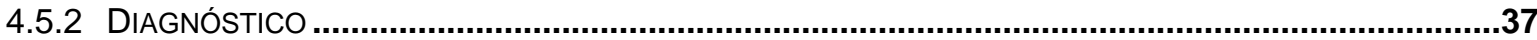

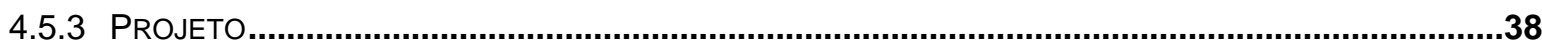

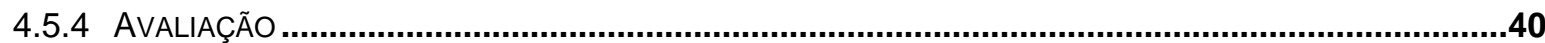

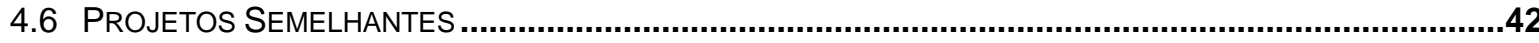

5 ESTUDO DE CASO: PROJETO CONTE ESTA HISTÓRIA - MALA DO LIVRO .....47

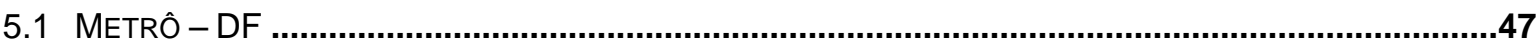

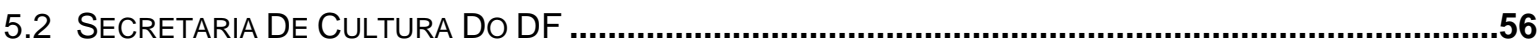

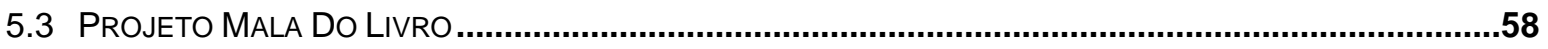

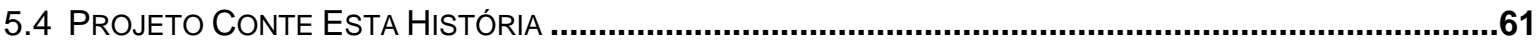

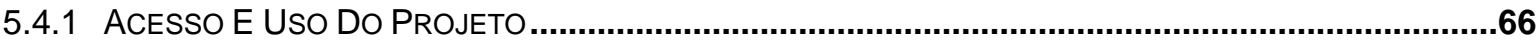

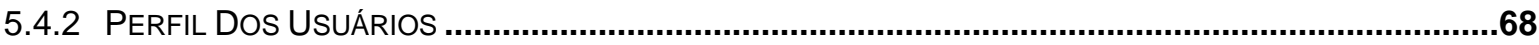

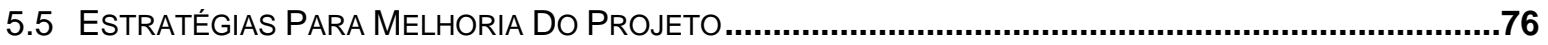

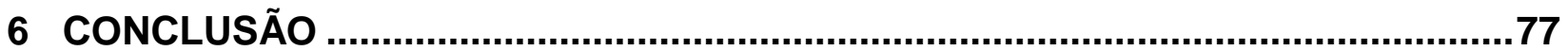

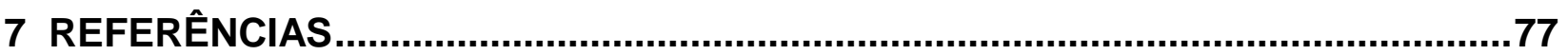

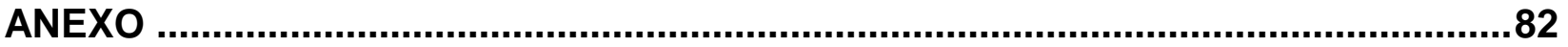




\section{INTRODUÇÃO}

No Brasil, a ausência do hábito da leitura é uma realidade histórica, que atinge a maioria da população com índices muito abaixo do ideal. De acordo com a pesquisa "Retratos da Leitura no Brasil", realizada pelo Instituto PróLivro (2008), o brasileiro lê, em média, 3,4 livros por ano. A pesquisa mostra ainda que $73 \%$ da população brasileira não freqüentam bibliotecas, e que $79 \%$ dos brasileiros não compram nenhum livro por ano.

Essa distância da população brasileira com a leitura pode ser explicada por diversos fatores. Um deles é a falta de estímulo da leitura na escola, lugar onde a maioria das pessoas tem o único contato com o livro. Para piorar a situação, em grande parte das escolas a biblioteca é usada apenas para a elaboração de trabalhos escolares, tornando-se um lugar pouco usado para a prática da leitura. Outro fator é a evolução da tecnologia, começando com a televisão até a chegada da Internet, onde são facilmente encontrados entretenimento e informação prontos para o "consumo".

Às bibliotecas públicas compete o papel de proporcionar o acesso à informação e à leitura, bem como contribuir para o desenvolvimento da sociedade em que está inserida. Porém, há municípios brasileiros que não têm uma biblioteca sequer, e os que têm, na maioria das vezes, possuem acervo defasado e recursos humanos despreparados para um processo de formação de leitores.

No entanto, têm-se buscado novas soluções para o problema da leitura no país. São lançados, anualmente, programas do governo e de iniciativas privadas que incentivam o hábito da leitura na população. Um deles é o Projeto Mala do Livro, da Secretaria de Cultura do Distrito Federal, que consiste na instalação de mini-bibliotecas em residências e locais de difícil acesso ao livro.

O Projeto Conte esta História é uma expansão do Projeto Mala do Livro, que leva o livro às estações do Metrô. O projeto tem pouco mais de um ano de existência e desenvolve um papel transformador junto à comunidade, pois atinge um grande número de pessoas, em local de constante fluxo de usuários, em seus períodos de locomoção, melhorando a democratização do acesso ao livro e à leitura. 


\section{OBJETIVOS}

\subsection{Geral}

Contribuir para a ampliação e efetividade do Projeto "Conte esta História Mala do Livro", por meio de seu estudo e sugestões.

\subsection{Específicos}

- Explicitar a importância do acesso à informação e à leitura para o desenvolvimento da sociedade.

- Caracterizar a biblioteca pública.

- Conhecer o programa Mala do Livro e outros projetos semelhantes.

- Compreender a estrutura e o funcionamento do Metrô - DF.

- Verificar o funcionamento e a estrutura da Secretaria de Cultura do DF e seus projetos.

- Analisar o projeto Conte esta História, suas estatísticas e resultados.

- Estabelecer o perfil dos usuários do projeto.

- Sugerir melhorias para o projeto. 


\section{METODOLOGIA}

Esta monografia foi elaborada em três partes: revisão de literatura, estudo de caso e sugestões de melhoria.

$\mathrm{Na}$ revisão de literatura foram pesquisados documentos relevantes para o tema, como livros, artigos de periódicos, sites da Internet, anais de congresso e dissertações.

No estudo de caso, foi analisado o projeto Conte esta História Mala do Livro. Inicialmente foi feito um estudo sobre a Secretaria de Cultura, com relação a criação do programa, e mais especificamente a Diretoria de Bibliotecas, que o mantém. Também foi analisada a parceria com o Metrô DF, que cedeu o local para a realização do projeto. Por fim, foi aplicado um questionário para conhecer o perfil dos usuários e suas necessidades e demandas.

A partir da revisão de literatura e do estudo de caso, propõe-se estratégias de melhorias, para que o projeto continue cumprindo seus objetivos e se amplie, atingindo ainda mais a população usuária do sistema Metrô. 


\title{
4 REVISÃO DE LITERATURA
}

\subsection{SOCIEDADE DA INFORMAÇÃO E DO CONHECIMENTO}

A partir da década de 60, vários autores têm demonstrado que a economia se desloca da indústria para os serviços, da força para 0 conhecimento, sendo esse novo tempo denominado economia do conhecimento, sociedade pós-industrial, sociedade pós-moderna, terceira onda, ou Sociedade da Informação. Moore (apud IBICT, 1998) defende que:

\begin{abstract}
Sociedade da informação se define pela existência de uma indústria local da informação (equipamento, serviços e conteúdos) capaz de satisfazer a demanda interna e de participar do mercado internacional, estando na base de sua manifestação o desenvolvimento econômico de longo prazo e o desenvolvimento tecnológico (MOORE apud Ministério da ciência e tecnologia, 1998, p. 89).
\end{abstract}

Durante a etapa industrial, o fator de riqueza era determinado pela posse dos meios necessários para possibilitar a transformação das matérias-primas em mercadorias (o capital); já na etapa pós-industrial o fator de riqueza passa a ser determinado pela posse da informação (FURLAN, 1991, p. 2). Se a sociedade industrial trouxe no seu bojo elementos como máquinas e ferramentas, trabalhadores especializados, produção em série, energia, entre outros, enfim, tudo voltado para a produção de bens materiais, a sociedade pós-industrial consolida-se na experiência organizacional, no investimento em tecnologia de ponta, nos grupos de especialistas, na produção modular, na informação, isto é, na geração de serviços e na produção e transmissão da informação (CARVALHO E KANISKI, 2000).

Masuda (1980) define sociedade da informação como uma sociedade em que o peso do sistema econômico produtivo é cada vez mais centrado no fator informação, assim como os sistemas sociais anteriores foram caracterizados como sociedade caçadora, sociedade agrícola e sociedade industrial.

Este novo modelo de organização das sociedades assenta num modo de desenvolvimento social e econômico onde a informação, como meio de criação de conhecimento, desempenha um papel fundamental na produção de riqueza 
e na contribuição para o bem-estar e qualidade de vida dos cidadãos. Porém, um outro ponto importante sobre a sociedade da informação está representado na dicotomia que traz seu objeto: a informação pode tanto ser fator de dominação quanto de emancipação. O conhecimento, enquanto força de produção, representa o ponto nevrálgico entre os países centrais e os países periféricos (CARVALHO E KANISKI, 2000). Os países centrais que, ao longo da história da humanidade, sempre lutaram pelo domínio de espaços territoriais, pelo acesso e exploração de matérias-primas e da força operária barata, agora competem também pelo domínio do conhecimento científico e tecnológico, representado aqui pela acumulação, processamento, armazenamento, acesso e disponibilização de informações por meio de redes de telecomunicações, quando o índice de uso da telemática passou a ser fator diferencial entre países desenvolvidos (centrais) e países em desenvolvimento (periféricos), incluindo o tipo de informação veiculada por essas redes (CARVALHO E KANISKI, 2000).

Considerando que a globalização não tem levado à distribuição equânime do conhecimento nem à preservação de valores culturais nacionais, a Unesco se engajou nas atividades de desenvolvimento da sociedade da informação, com o propósito de "promover o bem comum da humanidade e o livre intercâmbio de idéias e conhecimento" (IBICT, 1998, p. 94). Dentro desse propósito, os programas da Unesco na área objetiva assistir os países membros, assegurar acesso à informação e o direito de comunicação, e manter a diversidade cultural.

Borges (2000, p. 29) resume a sociedade da informação e do conhecimento caracterizando-a com alguns itens:

- a informação é um produto, um bem comercial;

- o saber é um fator econômico;

- as tecnologias de informação e comunicação vêm revolucionar a noção de "valor agregado" à informação;

- a distância e o tempo entre a fonte de informação e o seu destinatário deixaram de ter qualquer importância; as pessoas não precisam se deslocar porque são os dados que viajam;

- a probabilidade de se encontrarem respostas inovadoras a situações críticas é muito superior à situação anterior; 
- as tecnologias de informação e de comunicação converteram o mundo em uma "aldeia global" (MacLuhan);

- as novas tecnologias criaram novos mercados, serviços, empregos e empresas;

- as tecnologias de informação e comunicação interferiram no "ciclo informativo", tanto do ponto de vista dos processos, das atividades, da gestão, dos custos etc.:

- o próprio usuário da informação pode ser também o produtor ou gerador da informação;

- registro de grandes volumes de dados a baixo custo;

- armazenamento de dados em memórias com grande capacidade;

- processamento automático da informação em alta velocidade;

- recuperação de informação, com estratégias de buscas automatizadas;

- acesso às informações armazenadas em bases de dados em vários locais ou instituições, de maneira facilitada;

- monitoramento e avaliação do uso da informação.

No Brasil, ao longo da década de 90, registraram-se sucessos em aspectos críticos para a formulação e implementação do programa Sociedade da Informação. A Internet teve grande impulso, primeiramente na comunidade científica, e logo após a serviços de natureza comercial, desde 1995. Nas telecomunicações, houve a privatização de todo sistema brasileiro e a criação da Agência Nacional de Telecomunicações, fatores que estão permitindo maior e mais rápida disponibilidade de acesso aos meios de comunicação. Algumas aplicações do governo têm tido enorme impacto, tanto na melhoria da eficiência interna de funcionamento como na prestação de serviços ao cidadão. E, por último, comparativamente com a América Latina, existe uma sofisticada base tecnológica instalada no país e um considerável contingente de recursos humanos qualificados, abarcando desde pesquisa e desenvolvimento até fomento a empreendimentos (LIVRO VERDE, 2000, p.5).

Uma verdadeira sociedade da informação só se instala em ambiente democrático, dentro do qual operem cidadãos livres, educados e informados. Por isso os projetos nacionais têm-se fundamentado em instituições culturais e educacionais, isto é, bibliotecas, museus, arquivos, editores, escolas e 
similares, tendo como suporte e canal as tecnologias da informação e comunicação.

Segundo Miranda (2000) um elemento essencial para a construção da sociedade da informação no Brasil é a implantação de uma sólida plataforma de telecomunicações, na qual possam difundir-se e florescer as aplicações em áreas de alto conteúdo e retorno social, como educação, saúde, meio ambiente, agricultura, indústria e comércio. Requer a instalação e o fortalecimento de adequada infra-estrutura de escolas, bibliotecas e laboratórios, a fim de que uma nova geração de brasileiros se prepare para o futuro.

\subsection{ACESSO À INFORMAÇÃO}

A informação é o conhecimento registrado capaz de modificar a estrutura cognitiva de um receptor além de conter dados relevantes para a tomada de decisão (LE COADIC, 1996). Segundo Ferreira (1997) a informação é essencialmente uma ferramenta valiosa e útil para os seres humanos em suas tentativas de prosseguir com sucesso suas vidas. Milanesi (2003) afirma que não há formação sem informação.

A informação, quando adequadamente assimilada, produz conhecimento, modifica o estado mental de informações de indivíduos e traz benefícios ao seu desenvolvimento e ao desenvolvimento da sociedade em que ele vive (BARRETO, 1994). De acordo com o relatório da UNESCO (1995, apud RIBAS; ZIVIANI, 2007, p. 53) "o acesso à informação é um direto que temos, como o acesso à justiça, e deveria ser assegurado gratuitamente como outros serviços públicos". De acordo com Milanesi (2003):

É um direito do homem o acesso à informação, ao conhecimento. Para que isso, na prática, possa ser efetivado é preciso criar serviços capazes de colocar à disposição das pessoas tudo o que elas desejam e precisam conhecer. Aquilo que é considerado como "patrimônio cultural da humanidade" deve estar ao alcance de todos, independente da classe e idade, bem como toda e qualquer informação que possa ser do interesse coletivo (MILANESI, 2003, p. 192). 
O acesso à informação é uma questão de justiça. E a falta dela significa injustiça social. Quando não é elitizada a informação, seja por desigualdade social, seja por preconceito, ela pode estar negligenciada, relegada a segundo plano, aos setores da sociedade realmente interessados, à vida acadêmica, aos privilegiados (SANTOS, 2006).

Sabe-se que a informação não circula livremente em todos os setores da sociedade, inclusive porque a maioria dos cidadãos nem identifica suas necessidades informacionais, pois eles nunca dispuseram da mesma. Para Le Coadic (1996), a pessoa busca a informação quando existe um problema a ser resolvido, para o alcance de um objetivo, ou quando da constatação de um estado 'anômalo' do conhecimento, insuficiente ou inadequado.

Porém, a informação nem sempre é desejada, nem sempre há a necessidade de informação partindo do indivíduo. Segundo Milanesi (2003), as pessoas não só precisam encontrar o que desejam, mas precisam desejar o que, de fato, precisam. Ou seja, a necessidade informacional é algo não observável diretamente (COOPER, apud SILVEIRA; ODDONE, 2007).

De acordo com Barros, Saorim e Ramalho (2008), a necessidade de informação consiste na percepção de um vazio cognitivo, em que perpassa incertezas, dúvidas, angústias, todo tipo de manifestação que poderá ou não, canalizar forças no indivíduo para transpor tal situação. Para Kulthau (1991, apud BARROS; SAORIM; RAMALHO, 2008) necessidade de informação é o hiato que existe entre o conhecimento da pessoa a respeito de um problema e aquilo de que precisa saber para resolvê-lo.

Assim, "cada cidadão deveria estar consciente do direito à informação de que necessita, seja ela para capacitação profissional, desempenho de suas obrigações sociais ou para leitura recreativa" (MIRANDA, 1977, p. 179).

A obtenção da informação é tanto mais difícil e penosa quanto mais baixo seja o nível socioeconômico do indivíduo que a busca. Segundo estudos realizados pela bibliotecária Nice Menezes de Figueiredo (1987), enquanto nos níveis superiores socioeconomicamente a informação registrada ou impressa é utilizada para complementar a informação oral, nos níveis mais baixos isso não é possível, devido ao analfabetismo, à falta do hábito de leitura e ao baixo poder aquisitivo. 
É de responsabilidade do Estado desenvolver o processo educativo para criar essas demandas informacionais na população. Grande parte dos cidadãos não participa das questões públicas por desconhecimento de seus direitos e deveres na sociedade, pois para participar é necessário estar informado.

A democratização da informação é dever do Estado, para tanto, ele deve criar bibliotecas públicas que realmente atendam a demanda da população e, com isso, fomentar o hábito da leitura.

\subsection{IMPORTÂNCIA DA LEITURA}

Como disse Paulo Freire (2001), "a leitura do mundo precede sempre a leitura da palavra e a leitura desta implica a continuidade da leitura daquele". Assim, o ato de ler é fundamental para o ser humano. A leitura é essencial: constitui-se num elemento básico no acesso à informação. É a responsável pela formação de um cidadão crítico, criativo e inovador (OLIVEIRA; SIENNA, 2008). A leitura é uma atividade essencial a qualquer área do conhecimento e mais essencial ainda à própria vida do ser humano. (SILVA, 1981, p.42).

De acordo com Silva (1995), existem três categorias para a leitura. São elas: Informação, Conhecimento e Prazer. A leitura informativa serve para manter a pessoa atualizada acerca dos acontecimentos do dia-a-dia. Geralmente é encontrada em semanários ou mensários. A leitura do conhecimento está diretamente relacionada com os processos de pesquisa e estudo, mais encontrada em livros didáticos. A leitura de prazer é relacionada ao lazer do indivíduo, encontrada em textos literários. Este tipo de leitura é a mais difícil de ser absorvida pela população, por diversos motivos que mais tarde serão explicitados neste trabalho.

Desde o aparecimento da imprensa, a leitura é considerada instrumento dos mais importantes na aquisição das informações, as quais, se forem significadas pelo sujeito e apropriadas para seus diferentes contextos, constituir-se-ão em conhecimento (BARRETO, 2005). Embora valorizada socialmente, a leitura não é associada ao lazer para boa parte da população (ALENCAR, 2006). 
No Brasil têm se falado da crise da leitura, que é a ausência de leitura de texto escrito, principalmente livros (MARTINS, 2006). Mas o hábito de ler já não existe na sociedade brasileira desde o período colonial, com a discriminação e marginalização no processo de formação de leitores. Segundo Silva (1995), essa crise advém da participação desigual das classes sociais no que tange ao acesso e à fruição dos conhecimentos veiculados pela escrita. Mais especificamente, $\mathrm{o}$ ato de ler se constitui num instrumento de luta contra a dominação das classes socioeconomicamente mais altas. De acordo com Silva (2005):

$\mathrm{O}$ ato de ler é, fundamentalmente, um ato de conhecimento. $\mathrm{E}$ conhecer significa perceber mais contundentemente as forças e as relações existentes no mundo da natureza e no mundo dos homens, explicando-as. Aos dominadores, exploradores ou opressores interessa que as classes subalternas não percebam e nem expliquem as estruturas sociais vigentes e o regime de privilégios (SILVA, 2005, p. 12).

O hábito da leitura deve ser incentivado desde a infância. O exemplo que a criança tem em casa é o mais valioso, por isso quando ela vê os pais em diversas oportunidades 'agarrados' a livros ou mesmo periódicos, terá maior facilidade a valorizar tal ato instintivamente (SANDRONI, L. C.; MACHADO, L. R., 1987). Como explica Silva (1995):

\footnotetext{
A formação do gosto pela leitura depende do conjunto de interações, do circuito educativo em torno dos livros, sendo que todas as pessoas envolvidas no processo (incluindo bibliotecários, professores, e pais), precisam conhecer os referenciais pretendidos pelas obras, precisam sentir a beleza da palavra literária, precisam viver - na prática - o prazer da leitura (SILVA, 1995, p. 95).
}

Ao contrário do ideal, a maior parte de população só tem contato com a leitura na escola. Bortolom (1998) diz que "no Brasil a escola talvez seja o único lugar onde a grande maioria das pessoas tem contato com o livro". Porém, ao invés de formar leitores e de incentivar a leitura, a escola, através de seus professores, de seus programas e de seus métodos, age exatamente em sentido contrário, matando paulatinamente todo o potencial de leitura do mundo e da palavra que as crianças trazem para o contexto escolar (SILVA, 1995). 
Como esclarece Freitas (et al., 1986) a falta do hábito de alguns professores em utilizar livros como recurso ensino-aprendizagem demonstrou que a metodologia por eles utilizada, sem a orientação do grupo, poderá provocar nos seus alunos uma certa rejeição pela leitura com prazer.

Segundo Milanesi (2003) a prática da leitura na escola não significa um exercício para desenvolver o gosto pela busca do conhecimento, mas sim, uma iniciação obrigatória de cópia, uma tarefa mais ou menos incompreensível de aproximação do literário. Isso também acontece porque os textos que os alunos são obrigados a ler nada têm a ver com o contexto que eles vivem no momento. De acordo com Freire (2001) é grande a distância entre o que é lido nas escolas e o mundo das experiências pessoais, o mundo em que todos vivem suas vidas, com experiências personalíssimas.

A condição básica para ensinar o aluno a ler diz respeito à capacidade de leitura do próprio professor. Para que ocorra um bom ensino da leitura é necessário que o professor seja, ele mesmo, um bom leitor (MARTINS, 2006).

Os pais, que na maior parte dos casos não têm o hábito da leitura, só o que importa é o diploma de conclusão de curso, pois este tem um grande significado social (SILVA, 1995).

Outro fator que colabora para as pessoas se afastarem da leitura é o avanço tecnológico, com o surgimento da televisão e rádio. Como diz Milanesi (2005) "os meios de comunicação preenchem espaços e ocupam áreas anteriormente utilizadas para outras práticas, tomam o lugar da escola enquanto fonte básica do conhecimento e das leituras como forma permanente de atualização".

A televisão é o maior instrumento de informação da sociedade de hoje, um envolvente formatador de mentalidades, ela age de tal forma que é o suficiente para as necessidades informacionais da população. Ela passou a responder e criar dúvidas, mais responder do que criar, ou pelo menos, não criar dúvidas que ela própria não pudesse responder (MILANESI, 2002).

Outro advento que contribui para distanciar as pessoas da leitura e, principalmente crianças em fase escolar, é a Internet. Ela pode, sim, ser um poderoso elemento para o hábito da leitura e da escrita, nas conversas virtuais e nos passeios pela rede, podendo ajudar, principalmente, nas pesquisas escolares. Mas o que acontece, na prática, é que ela é usada apenas para 
entretenimento, sem a menor preocupação com o conteúdo que se está lendo, e, quando é usada nas pesquisas escolares, é na maioria das vezes no esquema "copiar e colar".

Leitura ainda é a ação que vai garantir o acesso às informações escritas, em qualquer suporte material nos quais elas se encontrem.(BARRETO, 2005).

\subsection{BIBLIOTECA PÚBLICA}

A biblioteca pública é um espaço sociocultural que leva à sociedade informação e conhecimento. Ao longo do tempo foi adaptando-se as mudanças de seus usuários tornando-se uma instituição mais democrática. Deixou de ser um 'depósito de livros' e passou a ter um papel relevante na sociedade. Seu histórico no Brasil vai de uma vinda 'fracassada' da Biblioteca e da Imprensa Real em meados do século XIX até os dias de hoje onde é considerada um centro cultural, como afirma Milanesi (2003, p. 214):

No Brasil, nesta última década do século $X X$ não é mais possível construir uma biblioteca pública e um centro de Cultura, como entidades distintas. Há muito a primeira deixou de ser apenas uma coleção de livros e a segunda não pode existir sem que as informações estejam disponíveis. O caminho é o espaço polivalente onde as pessoas encontram as possibilidades de pensar e de se expressar com a liberdade possível.

As bibliotecas conceituam-se como instituições que foram criadas há séculos e que evoluíram e continuam a evoluir, para melhor atender as necessidades da sociedade e como meio de seu desenvolvimento, nelas é possível o acesso a qualquer tipo de informação. Dentro deste contexto vemos a biblioteca pública como um aparato extremamente importante de inclusão social, de acordo com Marc Baratin e Cristian Jacob (2006, p. 32):

Lugar da memória nacional, espaço de conservação do patrimônio intelectual, literário e artístico, uma biblioteca é também o teatro de uma alquimia complexa em que, sob o efeito da leitura, da escrita e de sua interação, se liberam as forças, os movimentos do pensamento. É um lugar de diálogo com o passado, de criação e inovação, e a conservação só tem sentido como fermento dos saberes e motor dos conhecimentos, a serviço da coletividade inteira. 
Historicamente, as bibliotecas tiveram diferentes compreensões, reproduziam o tipo de sociedade de terminado local e a época que estava vivenciando. Até o início do século XIX, a biblioteca era tida como um arquivomuseu, lugar de memória e depósito de patrimônio bibliográfico (BARRETO, PARADELLA E ASSIS, 2008). Segundo Almeida Júnior (1997, p. 22):

\begin{abstract}
A origem da biblioteca púbica não pode ser entendida, simplificadamente, como oriunda dos reclamos das classes populares ou, inversamente, pelas benesses das classes detentoras do poder. Aquele momento histórico (meados do século $X I X)$ leva-nos a reconhecer a influência, a mescla, a intersecção dessas e de outras causas. A biblioteca pública surge não isoladamente, deslocada dos acontecimentos e da situação da sociedade naquela época. Ao contrário, ela está imersa nas transformações, nas mudanças e alterações daquela época e, assim, deveria continuar participando de cada cenário histórico, cenários não estanques, mas dinâmicos e em constante mutação. A biblioteca pública deve ser reflexo e causa das transformações da sociedade; deve receber influências, interferir, ser início, meio e fim das alterações sociais, numa seqüência interminável. Sua origem esteve sustentada por esse quadro.
\end{abstract}

O homem por natureza cria, produz e registra. Com o passar dos séculos viu-se a necessidade de organização de toda essa diversidade de informações e conhecimento. Um dos fatores mais importantes para a criação de um histórico da Biblioteca Pública é a linguagem. Este elemento fundamental para a construção do conhecimento é uma prática inerente do ser humano no convívio social, reflexo do pensamento, forma primordial da comunicação. Por isso torna-se a principal fonte de controle da informação.

Assim, o homem da caverna utilizando as mãos nas primeiras tentativas de talhar a pedra, exercia na realidade um prodigioso esforço de abstração, trabalhava mentalmente, na sua rudeza bronca, mais que o grande sábio moderno, precedido de toda uma civilização preparatória: a mão, fazendo a coisa, graças ao comando de um espírito ainda obscuro e pesado, ia, por seu lado, permitir o aparecimento da linguagem, e mesmo a provocá-lo. Que seja o nome ou o grito, a frase ou a palavra que tenham aparecido inicialmente, a linguagem representava o princípio da grande dominação do homem sobre as coisas (MARTINS, 1996, p.19). 
Instalada a linguagem, independente de sua forma representada, através de figuras, idéias, sinais gráficos ou mesmo na forma oral, passa a ser 0 controle humano sobre seu mundo, a concretização da transformação na sociedade. E utilizando-se de vários materiais para o registro de seu conhecimento o homem foi difundindo as suas idéias, expandindo sua instrução, levando às futuras gerações o saber.

Historicamente não se sabe ao certo quando a biblioteca surgiu, mas há registros de organização desde o Egito antigo onde milhares de papiros eram organizados por escribas. Este material vegetal que permitiu ao homem registrar com mais facilidade suas manifestações comunicativas. Segundo Mello (1979, p. 75) "o papiro, que surgiu na mesma época do papel chinês, foi a grande oportunidade que se ofereceu ao Homem, para realizar seu maior desejo: comunicação e diálogo". Na Idade Média surgiu o pergaminho, que permitia a escrita frente e verso, porém quem detinha o poder da informação era uma pequena parte da sociedade, muitas vezes essa informação nem mesmo saia dos locais onde era concebida.

Todos esses instrumentos de registro da linguagem já possuíam a idéia de livro e de bibliotecas, na transcrição do pensamento, das idéias. O sistema informacional criado nesta época trazia descobertas, lutas e revoluções gerando uma grande e importante fatia da memória social da humanidade. As bibliotecas surgiam mitificadas uma vez que a maioria delas encontrava-se sediadas nas moradas dos reis, templos e demais autoridades. O público era restrito a intelectuais, autoridades, religiosos e demais poderosos da época, o conhecimento era detido por poucos.

A biblioteca pública surge na Inglaterra, em 1850. Nesse período, nos Estados Unidos e na Inglaterra, são promulgadas leis que autorizavam o emprego de certa percentagem dos impostos na construção e manutenção das bibliotecas públicas. As características dessa biblioteca, que a diferenciavam das anteriores, é que era regulamentada pelo Estado e possuíam funções específicas e a intenção de atender a toda a sociedade, principalmente visando a alfabetização. 
Para Araújo (2002, apud NOGUEIRA,1983):

[...] A ideologia vigente naquela época, ao preconizar a liberdade e a igualdade como direitos de todos os indivíduos, deu suporte para o surgimento de movimentos de massa, que exigiam a democratização, enquanto que as inovações técnicas dos instrumentos de trabalhos, ao promoverem a necessidade de melhor adestramento da mão-de-obra disponível, davam força à pressão da massa para obter maior qualificação. [...] $\bigcirc$ governo inglês frente às condições expostas, implantou bibliotecas públicas como mais um instrumento para facilitar uma maior especialização da mão-deobra, visando atender as transformações ocorridas no processo de produção e, simultaneamente, atender à pressão da massa, no sentido da universalização da educação. Porém, através da forma e conteúdo proposto pelo Estado, esse organismo cultural se constitui, também, em mais um mecanismo para resgatar e controlar os movimentos das massas trabalhadoras. (NOGUEIRA 1983, p. 208)

Nos últimos séculos a humanidade deu grandes saltos no uso e diversificação dos meios de comunicação, registrados ou transmitidos: das cartas aos incunábulos, do desenvolvimento da imprensa ao telégrafo, do telefone ao fax, do computador aos produtos convergentes das multimídias reunidas na tela do computador.

A preocupação consiste na preservação da memória, da cultura, dos saberes, seja para organizar, disseminar, acessar, recuperar ou para usar a informação registrada.

Agora, no século $\mathrm{XXI}$, o mundo está se preparando para progredir cada vez mais por meio das novas tecnologias e das novas redes. Conforme Borges (2000), conclui-se que a sociedade da informação e do conhecimento é uma realidade. É uma resposta à dinâmica da evolução, ao crescimento vertiginoso de experiências, invenções, inovações, dentro de um enfoque sistêmico - onde a interdisciplinaridade é fator determinante - em franco desenvolvimento e renovador, principalmente, para países mais pobres, mais despreparados, onde se tornou uma esperança de crescimento e desenvolvimento para poderem se aproximar dos países economicamente prósperos, porém dentro de uma perspectiva de renovação de ideal. 


\subsubsection{Histórico das Bibliotecas Públicas no Brasil}

Com a instalação do Governo-Geral e a vinda dos jesuítas para a catequização dos índios, na segunda metade do século XVI, na Bahia, chegaram ao Brasil, na bagagem desses religiosos, os primeiros livros. Os acervos foram aumentando e tornaram-se de uso particular dos jesuítas, não havendo no país nenhum outro tipo de biblioteca ou livraria, que fomentasse a formação de leitores, pois ninguém mais se interessava em lê-los, uma vez que mais de $80 \%$ da população era constituída de analfabetos, incluindo os colonizadores (VALIO, 1990).

As bibliotecas conventuais existiram até a segunda metade do século XVIII e baseavam-se na seleção e expurgo de obras que não fossem pertinentes ao ideal da Coroa e da Ordem Religiosa.

Com a vinda da Corte Portuguesa de Lisboa para o Brasil, em 1808, transforma-se a situação do país em todos os setores e traz a inserção ao contexto cultural com a vinda da Biblioteca Real da Corte, que foi instalada no Rio de Janeiro e de acordo com Brambila apud Moraes (2005, p.51), no Hospital da Ordem Terceira do Carmo, em 1811. Aberta ao público três anos depois, em 1814, foi incorporada ao Estado em 1825, por meio de um tratado com Portugal. Com a Independência do Brasil passou a denominar-se "Biblioteca Nacional".

Segundo Milanesi (1986), a primeira Biblioteca Pública, com o intuito de atender os cidadãos em geral, foi fundada em 04 de agosto de 1811, em Salvador, na Bahia, por iniciativa de Pedro Gomes Ferrão de Castelo Branco e de um grupo de cidadãos associados.

A Biblioteca Pública da Bahia iniciou-se sem nenhuma verba ou local específico, deveria funcionar com seus próprios recursos. Assim teve que se manter por meio de doações de pessoas interessadas em prover os recursos financeiros para a aquisição de acervo, de mobiliário, de materiais necessários para os serviços, inclusive para o pagamento dos recursos humanos. Inicialmente foi inaugurada no Convento dos Jesuítas, mudando de lugar por várias vezes. De acordo com Araújo (2002):

A implementação da biblioteca pública da Bahia, bem como de outras bibliotecas públicas, não viria atender à grande maioria 
(analfabeta e escravizada) da população brasileira. Foi o objetivo liberal de "educação para todos" que motivou o surgimento da "biblioteca para todos", ou seja, da biblioteca pública brasileira. Entretanto, entre este objetivo e a prática desenvolvida por esta instituição, havia um enorme descompasso, pois eram administradas, organizadas e utilizadas por intelectuais com formação principalmente européia, e, por outro lado, devido ao seu acervo (basicamente composto de registros gráficos), esta instituição era inacessível à grande maioria de analfabetos, que compunham a população brasileira da época. Assim, a biblioteca pública brasileira, durante o período colonial e imperial, pode ser considerada como uma instituição cultural elitista e alheia às necessidades educacionais e informacionais da maior parte da população (ARAÚJO, 2002, p.18).

Até a década de 1970, a maioria das bibliotecas públicas não possuía um local efetivo para seu funcionamento. Não havia uma política de promoção das bibliotecas públicas. Somente depois de um século e meio de existência, é que elas passaram a ter sede própria.

O alto índice de analfabetismo e a falta de políticas educacionais prejudicaram o esforço para aumentar o número de bibliotecas públicas no país, motivo pelo quais pouquíssimos governos estaduais e municipais, tiveram a iniciativa de criá-las.

Para Araújo (2002), biblioteca pública é a instituição que deve estar a serviço de todos os cidadãos, oferecendo-Ihes informação, cultura e lazer a partir de um modelo estatal de prestação de serviços e para que haja um modelo estatal, é necessário que existam políticas públicas direcionadas ao serviço, o que no Brasil só começou a acontecer em 1937, com a criação do Instituto Nacional do Livro - INL, que tinha entre suas competências incentivar a organização e auxiliar a manutenção de bibliotecas públicas em todo o território nacional e o aprimoramento de seus administradores.

A criação do Instituto Nacional do Livro, teve como resultado a intensificação da distribuição de livros no país, o que favoreceu a indústria editorial, e não a função social das bibliotecas públicas.

O primeiro diretor do INL foi Augusto Meyer, que elaborou diversos projetos para o setor. Entre eles, o projeto das bibliotecas centrais. Em 1940, o INL criou uma ação auxiliar junto às prefeituras e passou a aconselhar a criação de bibliotecas públicas e se dispondo a dar assistência, doando e intermediando aquisições de livros. Tal projeto foi a primeira proposta oficial 
para um sistema nacional de bibliotecas públicas, o qual previa que a direção seria exercida por bibliotecário formado pela Biblioteca Nacional. Previa também um sistema de permuta interbibliotecária, bibliotecas ambulantes e prestação de assistência às outras bibliotecas já existentes. Foi um projeto moderno para a época e apresentou a estrutura dos atuais sistemas de bibliotecas públicas.

\subsubsection{Função Social das Bibliotecas Públicas}

A história das bibliotecas surge na utopia de acumular todos os pensadores, suas obras e ciências e na preservação dos conteúdos sagrados em um espaço definido pela biblioteca que, além de conservar a memória e o patrimônio intelectual, possui políticas de conservação, promove mediações deste conhecimento e informação à sociedade. Sobre isso Araújo (2002, p. 15) afirma que:

Concepções e práticas de preservação e organização de documentos (principalmente registros gráficos) culminaram com a criação de bibliotecas. Desta forma, esta instituição firmou-se como memória coletiva das experiências existenciais, científicas e culturais das sociedades antigas e medievais.

A linguagem e o pensamento unem-se na construção do conhecimento e marcam a sociedade humana como um processo contínuo de transformação desse conhecimento.

Em seu "Manifesto sobre a Biblioteca Pública" a UNESCO (1994) afirma sua confiança na biblioteca pública como força para a educação, cultura e informação: "A Biblioteca Pública é uma demonstração prática da fé da democracia na educação universal considerada como processo contínuo ao longo de toda a vida e no reconhecimento de que a natureza do homem se realiza no saber e na cultura (...). A Biblioteca Pública deve ser estabelecida à base de dispositivos legais inequívocos que regulem a prestação de um serviço de biblioteca pública de alcance nacional (...). Sua manutenção deve ser assegurada totalmente pelos cofres públicos, não se exigindo qualquer 
remuneração direta pelos serviços que prestar. Para alcançar seus objetivos (...) deve ser de fácil acesso e suas portas estarão abertas a todos os membros da comunidade, sem distinção de raça, cor, nacionalidade, idade, sexo, religião, língua, situação social ou nível de instrução, para que a utilizem livremente em igualdade de condições.". O Manifesto ainda traz dois propósitos que chamam a atenção: garantir aos cidadãos todo o tipo de informação comunitária; facilitar o desenvolvimento da informação e da habilidade de uso de tecnologias.

Historicamente, as bibliotecas públicas sempre desempenharam um importante papel na sociedade. Inicialmente, voltadas para a preservação da memória da humanidade, as bibliotecas foram identificadas na obra de Humberto Eco e no imaginário das pessoas como locais elitistas e de acesso restrito. Contudo, isto talvez possa ser explicado pelo surgimento tardio das bibliotecas públicas, pois, de acordo com Almeida Júnior (1997), esta biblioteca pública que conhecemos, mantida pelo Estado para atender a toda sociedade e com o objetivo de dar suporte à educação, surgiu apenas na metade do século XIX, nos Estados Unidos e Inglaterra.

Assim como as bibliotecas desses países, as bibliotecas públicas brasileiras surgiram com o objetivo de dar suporte à educação. Porém, como organismos vivos que são e por estarem diretamente ligadas às transformações sociais, com o passar do tempo, evoluíram e incorporaram também as funções de lazer, cultura e informação (ALMEIDA JÚNIOR,1997).

Nesse aspecto uma biblioteca pública atua não apenas como guarda de memória (depósito de livros), mas sim como disseminadora do conteúdo do seu acervo, trazendo a sociedade um processo inclusivo tanto pelo acesso, uso e democratização da informação, científica e cultural, além das úteis e necessárias à atuação cotidiana da população. Como afirmam Barreto, Paradella e Assis (2008), vê-se a biblioteca pública como uma promotora da igualdade social, pela oferta de oportunidades a todos e como força viva para a educação, cultura e educação.

Para acompanhar as transformações políticas, sociais e culturais do mundo moderno, as bibliotecas públicas também mudaram o seu perfil de "depósito de livros", e tornaram-se instituições mais democráticas, devido aos questionamentos em torno do seu papel perante a sociedade, tendo em vista 
que atendiam somente aos anseios de uma elite letrada, detentora do conhecimento e que possuía o acesso facilitado àquelas instituições. Enquanto de um outro lado, a maioria da população estava à margem da informação para resolvendo problemas simples, ligados a seu cotidiano e suas necessidades básicas.

Sabe-se que o verdadeiro papel de uma biblioteca pública é servir aos interesses da comunidade, sem fazer distinção de condição social, raça, crença, ou nacionalidade, para que possa despertar nas pessoas a consciência da participação social de cada indivíduo. O serviço de informação à comunidade é o mais valioso instrumento que dispõe uma biblioteca pública; pois ao fazer isso, ela estará cumprindo sua verdadeira missão de levar a informação e o conhecimento a todos os cidadãos.

A Biblioteca Pública é uma instituição social, sua constituição e os serviços por elas prestados, denotam sua característica de instituição básica na estrutura de apoio ao desenvolvimento e sustentação de uma sociedade. Sua função social é oferecer democraticamente acesso ao livro, ao conhecimento e assim contribuir para o fortalecimento da cidadania e para o enriquecimento intelectual e cultural da comunidade, sobretudo dos estudantes, e também de servir como recurso pedagógico aos professores e educadores. Cuidar dos livros não é deixá-los intocáveis nas estantes. É possibilitar o acesso, o interesse do público para a leitura e exploração de todo conhecimento que eles reúnem.

Outra função social das Bibliotecas Públicas é possibilitar, através do acesso à informação e a criação do hábito da leitura, a construção de uma sociedade verdadeiramente democrática e a formação de uma consciência crítica do indivíduo levando-o ao exercício pleno da cidadania. Como centro de informação e leitura, possibilita o uso da informação como instrumento de crescimento pessoal e de transformação social.

Mário de Andrade, em 1939, (apud SNBP) assim se expressava a esse respeito:

A criação de bibliotecas populares me parece uma das atividades mais necessárias para o desenvolvimento da cultura brasileira. Não que essas bibliotecas venham resolver qualquer dos dolorosos problemas de nossa cultura [...] Mas a disseminação no pouco, do hábito de ler, se bem orientada, 
criará fatalmente uma população urbana mais esclarecida, mais capaz de vontade própria, menos indiferente à vida nacional.

A união de todas essas funções dá forma ao que conhecemos por função social da biblioteca pública, a qual é difícil dissociar de conceitos como democracia e cidadania. De acordo com Kerslake e Kinnell (1998), cidadania pressupõe não somente direitos civis, políticos e sócio-econômicos, mas também direito à informação. No entanto, sempre que o acesso à comunicação e aos recursos de informação necessários para a cidadania depende do poder aquisitivo, são geradas desigualdades que abalam a universalidade desse conceito.

A necessária atuação da biblioteca pública na construção de uma sociedade mais inclusiva e igualitária traz como conseqüência a incorporação de uma função adicional: a de garantir o acesso à informação também em meio digital, sobretudo na Internet. Nesta perspectiva, a Cumbre Mundial Sobre la Sociedad de la Información (2003) destaca a biblioteca pública como um importante instrumento no combate à exclusão digital e para assegurar o acesso contínuo ao meio eletrônico sem a interferência do mercado da informação.

Contudo, o simples acesso à informação, não é suficiente para a inclusão social dos cidadãos. É necessário que as bibliotecas públicas, assim como os telecentros, busquem atingir o segundo nível de inclusão digital, para que a informação seja transformada em conhecimento.

\subsection{PROCESSO DE PLANEJAMENTO}

No contexto de mudanças e incertezas de ordem política, econômica e social que se atravessa, é fundamental antecipar-se e planejar o futuro. Segundo Maciel (2006) a resposta para tal desafio estaria na adoção de metodologias que permitam à biblioteca competir por recursos cada vez mais competitivos.

Planejamento é o processo que antecede a ação, exige reflexão e auxilia a tomada de decisão. Estabelece, para cada parâmetro em questão, os resultados que se pretende atingir no futuro, levando o administrador a definir, 
previamente, o que, por que, como, quem deve fazer, o quanto custa, quando e onde deve ser feito. (MACIEL; MENDONÇA, 2006, p. 44). Para Holanda (1977) planejamento é a aplicação sistemática do conhecimento humano para prever e avaliar cursos de ação alternativos com vista à tomada de decisões adequadas e racionais, que sirvam de base para ação futura.

A falta do hábito de planejar leva muitas vezes o bibliotecário a detectar causas de maneira nebulosa, sem indicar especificamente a sua origem. Quando se tem mais objetivos de que meios para atingi-los é preciso definir quais deles são prioritários, quais têm mesmo que ser atingidos primeiro e quais podem ser deixados para depois, ou ainda, quais, se forem atingidos primeiro, ajudam a atingir os demais. (MACIEL; MENDONÇA, 2006).

De acordo com Maximiano (2000), o processo de planejamento é uma estratégia que as pessoas e organizações usam para administrar suas relações com o futuro, representando uma aplicação específica do processo decisório. A organização que planeja procura antecipar-se às mudanças em seus sistemas internos e no ambiente, como forma de garantir sua sobrevivência e eficácia. Conforme define Baptista (1981):

O termo "planejamento" se refere ao processo permanente e
metódico de abordagem racional e científica de problemas.
Enquanto processo permanente, supõe ação continuada sobre
um conjunto dinâmico de variáveis, em um determinado
momento histórico. Enquanto processo metódico de
abordagem racional e científica, supõe uma seqüência de atos
decisórios, ordenados em fases definidas e baseados em
conhecimentos científicos e técnicos (BAPTISTA, 1981, p. 13).

Baptista (1981) caracteriza o planejamento em 4 dimensões:
a) Dimensão racional
b) Dimensão política
c) Dimensão valorativa
d) Dimensão técnico-administrativa

Em seu aspecto racional, o planejamento é prática que norteia naturalmente as ações das pessoas, levando-as a planejar, mesmo sem se aperceberem de que o estão fazendo. 
A dimensão política decorre do fato de que ele é um processo contínuo de tomada de decisões, o que caracteriza ou envolve uma função política, seja da área governamental, seja da área privada.

A dimensão valorativa decorre do fato do mesmo favorecer 0 desenvolvimento de uma tecnologia que, se por um lado, possibilita soluções científicas para os problemas de uma sociedade em permanente mudança, por outro lado, viabiliza a centralização do poder e o aumento de sua eficácia controladora.

Quanto a dimensão técnico-administrativa, o planejamento é constituído pelas atividades que imprimem organização à ação, e que são realizadas pelos órgãos executores da política e da programação adotada.

O planejamento contém as seguintes fases processuais:

1ํ) análise e reflexão

$\left.2^{\underline{a}}\right)$ decisão

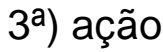

$4^{\mathrm{a}}$ ) revisão ou crítica.

$\mathrm{Na}$ fase da análise, realiza-se o reconhecimento da realidade onde se insere a ação planejada para que os serviços e produtos programados se atendam as demandas da comunidade envolvida.

A decisão, necessariamente apoiada na $1^{a}$ fase, é a colocação de objetivos e ação necessária para atingi-los.

Para Baptista (1981) a ação é relacionada à execução das decisões. É o foco central do planejamento, realiza-se por etapas preestabelecidas na operação anterior, a partir de instituições e de pessoal especificados.

A revisão ou crítica é uma avaliação de cada ação em curso, tendo em vista apontar desvios, atualizar procedimentos, ou mesmo, modificar o plano original (MACIEL, 2006). 


\begin{tabular}{|c|c|c|c|c|}
\hline $\begin{array}{l}\text { Operagies do Pro- } \\
\text { cesso Ractonal (1) }\end{array}$ & $\begin{array}{l}\text { Fases Proces. } \\
\text { srats (2) }\end{array}$ & Fases Metodologlcas & Recioctntos (s) & $\begin{array}{l}\text { Documentegio } \\
\text { Decomento }\end{array}$ \\
\hline \multirow[t]{3}{*}{ Baflexifo } & Sincrese & Fiscalha e Dellmitagho do Objeto & $\begin{array}{l}\text { Objetivo } \\
\text { Integranto }\end{array}$ & $\begin{array}{l}\text { Proposta } \\
\text { Prellinaliner }\end{array}$ \\
\hline & Andise Sintese & \begin{tabular}{|l|} 
Fistudo/Diagnostico: \\
- coleta salecho o processamen- \\
to de dados; \\
- estabelecimento do prioridades.
\end{tabular} & $\begin{array}{l}\text { Objetivo } \\
\text { Aonlitico } \\
\text { Integrante } \\
\text { Projetanto }\end{array}$ & Dtequóstioos \\
\hline & Crtaçbo & $\begin{array}{l}\text { Formulaça de Propostgbes Alter- } \\
\text { nativas de Intervença }\end{array}$ & $\begin{array}{l}\text { Objetivo } \\
\text { Otopico } \\
\text { Destétlco }\end{array}$ & $\begin{array}{l}\text { Instudos do } \\
\text { Vlabilidade } \\
\text { Aloteproletor }\end{array}$ \\
\hline Dedillo & $\log _{501}$ & $\begin{array}{l}\text { Escollhs de Prioridades } \\
\text { Escolha de Aiternativas } \\
\text { Delinigas de Objetiros a Metas }\end{array}$ & 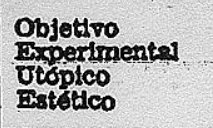 & $\begin{array}{l}\text { Planos } \\
\text { Programas } \\
\text { Projotos }\end{array}$ \\
\hline Aglio & intervenglio & $\begin{array}{l}\text { Implementaçán } \\
\text { Implantagto Execugra } \\
\text { Controle }\end{array}$ & $\begin{array}{l}\text { Objetivo } \\
\text { Experimentas } \\
\text { Exstético }\end{array}$ & $\begin{array}{l}\text { Rotelsos } \\
\text { Normas } \\
\text { Manuals } \\
\text { Relatórtos }\end{array}$ \\
\hline Rovlaso & Critica & $\begin{array}{l}\text { Avaliacsio } \\
\text { "Feod-Back" (Rretorno) }\end{array}$ & $\begin{array}{l}\text { Objetivo } \\
\text { Anallitico } \\
\text { Projotanto }\end{array}$ & $\begin{array}{l}\text { Relatórios } \\
\text { Avallativos }\end{array}$ \\
\hline
\end{tabular}

Fonte: Baptista, 1981, p. 21.

Figura 1: Síntese da Dinâmica do Processo de Planejamento

\subsubsection{TIPOS DE PLANEJAMENTO}

O planejamento numa organização pode ser visto de três perspectivas diferentes: planejamento estratégico, tático e operacional, destacando o primeiro como uma poderosa ferramenta para diferenciar competitivamente uma empresa no mercado e garantir seu crescimento e sucesso (MAXIMIANO, 2000).

O Planejamento Estratégico é definido ao nível Institucional da empresa e exige a participação integrada dos demais níveis empresariais: do nível Intermediário por meio dos planos táticos e do nível Operacional por intermédio dos planos operacionais.

O nível institucional lida com decisões globais, genéricas e amplas. Para que possa ser executado em todos os níveis da empresa, precisa ser adequadamente detalhado e desdobrado. Assim, no nível intermediário ele será desdobrado em planos táticos para cada departamento da empresa e, no nível operacional, cada plano tático será desdobrado e detalhado em planos 
operacionais relacionados com as tarefas e operações a serem realizadas (CHIAVENATO, 1994, p. 204).

\begin{tabular}{|c|c|c|c|c|}
\hline $\begin{array}{c}\text { Níveis da } \\
\text { empresa }\end{array}$ & Planejamento & Conteúdo & $\begin{array}{c}\text { Extensão } \\
\text { de tempo }\end{array}$ & Amplitude \\
\hline Institucional & Estratégico & $\begin{array}{c}\text { Genérico e } \\
\text { Sintético }\end{array}$ & $\begin{array}{c}\text { Longo } \\
\text { Prazo }\end{array}$ & $\begin{array}{c}\text { Macroorientado. } \\
\text { Aborda a empresa } \\
\text { como uma totalidade }\end{array}$ \\
\hline Intermediário & Tático & $\begin{array}{c}\text { Menos genérico } \\
\text { e mais } \\
\text { detalhado }\end{array}$ & Médio prazo & $\begin{array}{c}\text { Aborda cada } \\
\text { unidade da empresa } \\
\text { ou cada conjunto de } \\
\text { recursos }\end{array}$ \\
\hline Operacional & Operacional & Detalhado e & Curto prazo & $\begin{array}{c}\text { Microorientado. } \\
\text { Aborda cada tarefa } \\
\text { ou operação } \\
\text { isoladamente }\end{array}$ \\
\hline
\end{tabular}

Fonte: Chiavenato, 1994, p. 184.

Figura 2: O planejamento nos três níveis da empresa

Para Fischmann e Almeida (1991) Planejamento Estratégico é:

Uma técnica administrativa que, através da análise do ambiente de uma organização, cria a consciência das suas oportunidades e ameaças dos seus pontos fortes e fracos para o cumprimento de sua missão e, através desta consciência, estabelece o propósito de direção que a organização deverá seguir para aproveitar as oportunidades e evitar riscos (FISCHMANN, ALMEIDA, 1991, p. 25).

Segundo Chiavenato (1994) ele apresenta três características principais: é projetado a longo prazo, pelo menos em termos de seus efeitos e conseqüências; está voltado para as relações entre a empresa e seu ambiente de tarefa e, portanto, sujeito à incerteza a respeito dos eventos ambientais; e envolve a empresa como um todo, abarcando todos os seus recursos, no sentido de obter efeito sinergístico de todas as capacidades e potencialidades da empresa. 
Como explica Furlan (1991) o planejamento estratégico se dá através da indagação e resposta de três questões básicas: Onde estamos? Para onde iremos? e Como iremos? A primeira questão visa determinar o posicionamento atual da empresa no mercado. A pergunta 'para onde iremos' visa determinar as expectativas dos executivos com relação ao futuro da empresa. $\mathrm{E}$ a última questão, 'como iremos', visa determinar os meios e recursos necessários para que a empresa atinja os seus objetivos de curto, médio e longo prazos.

O Planejamento Estratégico exige seis etapas:

- Determinação dos objetivos empresariais

- Análise ambiental externa

- Análise organizacional interna

- Formulação das alternativas estratégicas e escolha da estratégia empresarial

- Elaboração do planejamento estratégico

- Implementação por meio de planos táticos e planos operacionais.

Essas etapas são flexíveis, de forma que sempre haverá a possibilidade do plano ser revisto. Na tabela seguinte estas fases estão resumidas, de acordo com Fischmann e Almeida (1991):

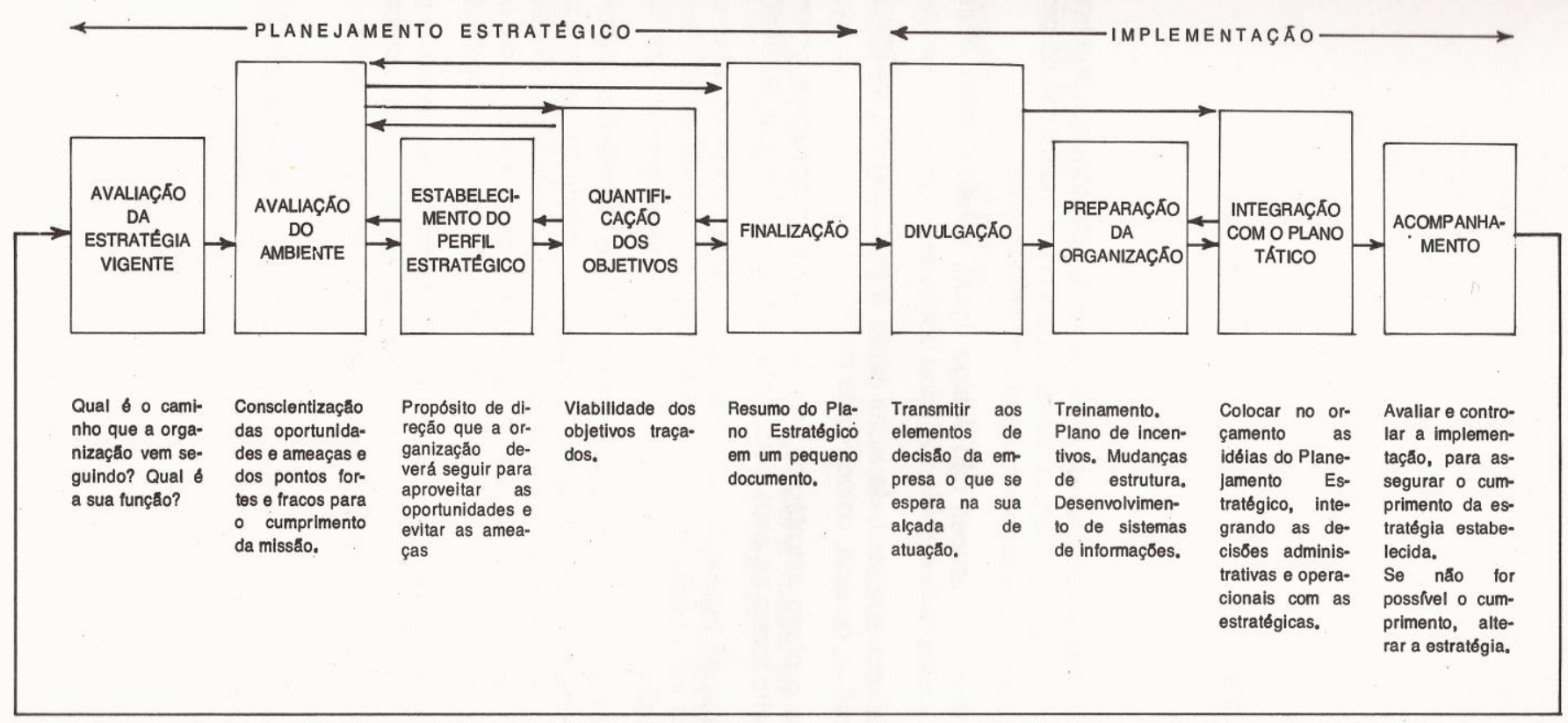

Fonte: Fischmann; Almeida, 1991, p. 33

Figura 3: Etapas do Planejamento Estratégico e sua Implementação 
O Planejamento Tático é um planejamento de médio prazo, predominantemente quantitativo, abrangendo decisões administrativas e operações e visando à eficiência da organização (FISCHMANN; ALMEIDA, 1991, p. 26). Ele transforma objetivos gerais em específicos para a execução de programas e projetos, decompõem diretrizes e normas em ações e dá o suporte necessário às decisões que indicam a direção a seguir.

O Planejamento tático é utilizado para traduzir os objetivos gerais e as estratégias da alta diretoria em objetivos e atividades mais específicos. $O$ principal desafio deste nível é promover um contato eficiente e eficaz entre o nível estratégico e o operacional. De acordo com Chiavenato (1994) suas principais características são: é projetado para o futuro próximo ou atividades atuais da empresa ao nível de departamentos, relacionado com o controle e integração das operações atuais da empresa, focalizando a alocação de recursos.

Enquanto o planejamento estratégico opera com a incerteza trazida do ambiente que circunda a empresa, o planejamento tático procura amortecê-la, neutralizá-la e contemporalizá-la para encaminhar, ao planejamento operacional, os esquemas de tarefas e operações devidamente racionalizados e submetidos a um processo reducionista típico de abordagem de sistema fechado (CHIAVENATO, 1994, p.233).

Para Almeida (2000) o Planejamento Operacional decide 'o que fazer' e 'como fazer'. Está ligado aos procedimentos, detalhando tarefas e operações, e deve estar sempre voltado à otimização dos resultados. Tem caráter imediatista, caracterizando-se por ser de curto prazo e de abrangência local.

O planejamento Operacional é constituído de uma infinidade de planos operacionais que proliferam nas diversas áreas e funções dentro da empresa. Esses planos, de acordo com Chiavenato (1994), podem estar relacionados com métodos, dinheiro, tempo ou com comportamentos.

Os planos relacionados com métodos são denominados procedimentos, e servem para estabelecer a seqüência de passos ou de etapas a serem seguidos para a execução dos planos. Os orçamentos são planos operacionais relacionados com dinheiro. Os programas são planos operacionais relacionados com o tempo, e os regulamentos são relacionados com comportamentos solicitados. 


\subsubsection{Diagnóstico}

Na opinião de Maciel (1993, p. 21):

Diagnóstico de uma biblioteca vem a ser, numa primeira etapa, - levantamento minucioso de dados sobre a sua estrutura administrativa, serviços que excuta e oferece, recursos humanos e materiais de que dispõe, instalações físicas e, obviamente, satisfação da clientela; e, numa segunda etapa, já de posse de todas as informações necessárias, a determinação das causas que levaram a biblioteca a um estado de inoperância.

Para Holanda (1977, p. 40) "diagnóstico é uma análise do passado que constitui a base factual, estatística ou histórica do processo de planejamento".

O diagnóstico possibilitará ao bibliotecário o direcionamento correto no seu trabalho, pois indicará, especificamente, os setores que estão bem organizados e os que apresentam falhas, evitando, em conseqüência, um esforço muito maior de reestruturação total. (MACIEL, 1993, p. 22). Neste sentido, são objetivos do diagnóstico: examinar, quantificar, qualificar e identificar os elementos do sistema que influenciam os co-sistemas da biblioteca e do usuário. Em outras palavras, o diagnóstico possibilita o exame, quantificação e identificação do problema, ou objeto do problema (MARTINS, 1980).

Cada objetivo do diagnóstico é composto por elementos que permitem a caracterização da situação do sistema, mas para isto é necessária uma programação, visando à coleta de informações. Assim, descreve Martins (1980):

- Para examinar é necessário conhecer qual a estrutura social da comunidade a ser servida pela biblioteca, os obstáculos às mudanças e a aceitação às mudanças;

- Para quantificar e qualificar é preciso que sejam conhecidas as modalidades de prestação de serviços bibliotecários à comunidade e ao próprio sistema, em suas técnicas, produção do sistema em relação aos custos e benefícios recebidos pela comunidade, em seus aspectos quantitativos e qualitativos; 
- Para identificar, serão utilizados os elementos demográficos, econômicos, pedagógicos, administrativos, políticos, técnicos e sociais.

O desenvolvimento do diagnóstico exige uma série de atividades que podem ser agrupadas em três principais etapas: preparação, elaboração do projeto do diagnóstico e implementação (ALMEIDA, 2000).

$\mathrm{Na}$ etapa de preparação do diagnóstico é definido os objetivos e metas organizacionais, a identificação de aspectos ou das áreas a serem avaliadas, o treinamento do pessoal e a revisão de literatura (ALMEIDA, 2000).

O processo de elaboração do diagnóstico envolve: o levantamento de hipóteses preliminares; a montagem de um quadro referencial; a coleta e o processamento dos dados de realidade; a reflexão diagnóstica e a identificação de prioridades de intervenção (BAPTISTA,1981, p. 28).

A implementação do diagnóstico envolve duas sub-etapas: a coleta de dados e a análise e interpretação desses dados (ALMEIDA, 2000).

A coleta de dados consiste na consulta de relatórios, manuais de serviços e outros documentos produzidos na instituição, e requer também entrevistas com os funcionários, a aplicação de questionários a usuários e a tabulação de dados. $\mathrm{Na}$ análise e interpretação dos dados, a unidade de informação tem acesso aos resultados do processo de avaliação e emite julgamentos de valor sobre serviços e atividades que devem ser modificados e sobre a forma de modificá-los (ALMEIDA, 2000).

\subsubsection{Projeto}

De acordo com Holanda (1977, p. 95) "em um sentido lato, projeto é qualquer propósito de ação definidora e organizado de forma racional". Para Baptista (1981) o projeto é o documento que sistematiza e estabelece o traçado prévio da operação de uma unidade de ação. É, portanto, a unidade elementar do processo sistemático de racionalização de decisões. Constitui-se da proposição de produção de algum bem ou serviço, com emprego de técnicas determinadas e com o objetivo de obter resultados definidos. 
O projeto corresponde ao conjunto de informações sistemática e racionalmente ordenadas, que nos permite estimar os custos e benefícios de determinado investimento (Holanda, 1977). "Ele é o instrumento mais próximo da execução, devendo detalhar as atividades a serem desenvolvidas, estabelecer prazos, especificar recursos humanos e materiais, e estruturar receitas e custos" (BAPTISTA, 1981, p. 58).

Martins (1980) explicita os aspectos a considerar na elaboração do projeto. São aspectos de diversos tipos: jurídicos, administrativos, contábeis, mercadológicos, de tamanho e localização, tecnológicos (engenharia) e metodológicos do projeto, e econômico-financeiros.

O projeto responde a determinadas questões. Essas respostas constituirão as partes que comporão o documento, conforme sugere Almeida (2000):

\begin{tabular}{|l|l|}
\hline \multicolumn{1}{|c|}{ Questões } & \multicolumn{1}{c|}{ Partes do documento } \\
\hline O que deve ser feito? & Objeto e objetivos \\
\hline Por que e para que deve ser feito? & Justificativas \\
\hline Como deverá se feito? & Etapas \\
\hline Quem deverá fazer? & Recursos humanos \\
\hline Com que meios? & Recursos materiais, físicos, etc. \\
\hline Quando deverá ser feito? & Cronograma \\
\hline Quanto deverá custar? & Custo total do projeto \\
\hline
\end{tabular}

Fonte: Almeida, 2000, p. 80.

Figura 4: Fases do projeto

$\mathrm{Na}$ etapa da definição dos objetivos, deve-se explicitar o que se quer atingir com o projeto, e devem ser considerados cinco princípios: coerência, aceitabilidade, exeqüibilidade, motivação e simplicidade. Na justificativa devem ser apresentadas as vantagens decorrentes da implantação do projeto. Ela deve basear-se na relevância do projeto para a solução dos problemas apontados no diagnóstico e procurar enfatizar o impacto do mesmo (ALMEIDA, 2000). 
$\mathrm{Na}$ etapa de metodologia são descritas como as atividades serão executadas para se cumprir cada uma das etapas. As etapas são compostas por metas, procedimentos e normas. O cronograma visa situar as etapas no tempo. Tem como vantagens permitir detectar o início e o fim de cada evento, verificar a sucessão das etapas e apontar os que se desenvolvem simultaneamente (ALMEIDA, 2000).

Os recursos podem ser vistos como o conjunto de meios ou instrumentos que possibilitarão o desenvolvimento do projeto. Quanto aos recursos humanos, trata-se do pessoal necessário ao desenvolvimento do projeto, que pode ser especialmente contratado para o mesmo. Os recursos materiais incluem material de consumo e material permanente, e devem ser discriminados dentro de cada categoria. Nos recursos físicos convém apontar a área física necessária para a implantação do projeto (ALMEIDA, 2000).

A previsão de custos indica os recursos necessários à execução do projeto, especificados por elemento ou categoria de despesa (ALMEIDA, 2000).

Embora nem sempre feita racionalmente, a difusão do projeto é essencial e serve para esclarecer objetivos e metas, benefícios econômico-sociais decorrentes do projeto e sustar boatos e interpretações errôneas sobre as ações planejadas (MARTINS, 1980).

\subsubsection{Avaliação}

A avaliação, no processo de planejamento, corresponde à fase em que o desempenho e os resultados da ação são examinados a partir de critérios determinados, com vistas à formulação de juízos de valor (BAPTISTA, 1981). As atividades de um serviço prestado pela biblioteca são avaliadas antes do planejamento, durante sua execução e depois dos resultados obtidos (MARTINS, 1980).

Segundo Martins (1980) a avaliação pode ser encarada sob diferentes critérios: 
a) Critério administrativo: planejamento, programação, execução, investimento, custos operacionais, despesa de material, equipamento, pessoal, instalações;

b) Critérios sociais: benefícios para a comunidade servida quanto aos resultados na ampliação ou melhoria dos conhecimentos, atitudes, habilidades e atendimento às expectativas dos usuários.

Baptista (1981) explica que os critérios mais usuais em avaliação são os relacionados com a eficiência, a eficácia e a efetividade da ação. Os critérios de eficiência são relacionados com o rendimento técnico e administrativo da ação, como o uso ótimo dos recursos disponibilizados, os padrões de qualidade dos resultados, etc. A eficácia é analisada a partir do estudo da adequação da ação para o alcance dos objetivos previstos no planejamento. $E$ a avaliação da efetividade diz respeito ao estudo da adequação dos objetivos definidos para o atendimento da situação-problema. Martins (1980, p. 140) esclarece que:
A avaliação tem sempre em vista os objetivos e metas estabelecidas no projeto e assim, além dos aspectos relacionados com a produtividade (eficiência) do projeto, procura principalmente avaliar se o que foi feito está em consonância com as metas e objetivos anteriormente definidos (eficácia).

A avaliação não deve ser uma ocorrência isolada, um evento, mas um processo contínuo por meio do qual programas e serviços sejam examinados a fim de garantir que objetivos e metas estejam sendo cumpridos (ALMEIDA, 2000).

Em uma avaliação, são considerados, de acordo com Baptista (1981):

- Os objetivos: sua adequação à situação-problema, suas especificações e seu alcance;

- O planejamento: os vários passos e as técnicas previstas para a realização da ação;

- A execução: a organização, os recursos, os procedimentos;

- Os fatores que facilitaram e os que dificultaram o desempenho;

- O produto da ação. 
Para Almeida (2000) o sucesso da avaliação depende, em primeiro lugar, de informações confiáveis, e em segundo lugar, da habilidade do pessoal que coordena o processo em lidar com os colegas ou os elementos envolvidos, a fim de fornecer informação útil ao planejamento organizacional e à tomada de decisão.

\subsection{PROJETOS SEMELHANTES}

As maneiras convencionais de disseminação da informação, cultura e lazer, das bibliotecas públicas e escolares, ainda deixam muito a desejar, seja pela dificuldade de acesso, seja pela escassez de tempo. Sabe-se que grande parte da população não freqüenta bibliotecas, por este motivo os governos resolveram investir em novas formas de disponibilizar esses serviços.

Comprar livros ou ir a uma biblioteca é privilégio para uma minoria em nosso país, principalmente, para quem mora nas periferias.

Com o intuito de aumentar a quantidade de leitores no Brasil e disseminar informação, vários projetos se propõem a estimular a população a ler, entre eles está o Projeto Bibliotecas nos Metrôs, idealizado pelo Instituto Brasil Leitor - IBL, que visa a criação de pontos de empréstimo gratuito de livros.

O IBL é uma organização voltada para a criação e gestão de projetos de estímulo à leitura e à educação, que idealizou as Bibliotecas nos Metrôs de alguns Estados. Trata-se da instalação de bibliotecas em estações de trem e/ou metrô de todo o Brasil, facilitando o acesso dos usuários aos livros. Segundo William Nacked, diretor geral do IBL, é preciso acabar com o mito de que o brasileiro não gosta de ler. É necessário facilitar o acesso a um acervo novo, de todas as áreas da literatura clássica e contemporânea, o que é feito, colocando os livros no caminho do usuário.

O projeto Bibliotecas em Metrôs é um módulo de empréstimo de livros de impacto visual onde a população tem a oportunidade de levar livros atraentes para casa. No total são nove bibliotecas em quatro estados brasileiros: São Paulo, Rio de Janeiro, Recife e Rio Grande do Sul. Elas somam aproximadamente 47 mil associados e 30 mil livros. Os acervos das bibliotecas contam com livros dos mais diversos estilos: literatura brasileira, auto-ajuda, 
best-seller, infanto-juvenil, filosofia, religião, ciências sociais, lingüística, artes e história.

\section{SÃO PAULO}

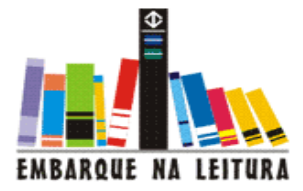

Em São Paulo são cinco unidades, nas estações da Luz, Tatuapé, Paraíso, Largo Treze e Santa Cecília. A Biblioteca Embarque na Leitura, nome do projeto paulista, inaugurada em 2004 na Estação Paraíso, em termos de empréstimos e número de associados é um referencial: emprestou cerca de 160 mil livros e tem mais de 17,3 mil associados. Em seguida, foram abertas as bibliotecas das estações Tatuapé, Luz, Largo Treze e Santa Cecília, todas na capital paulista. O Embarque na Leitura contabiliza, no total, 35.840 sócios.

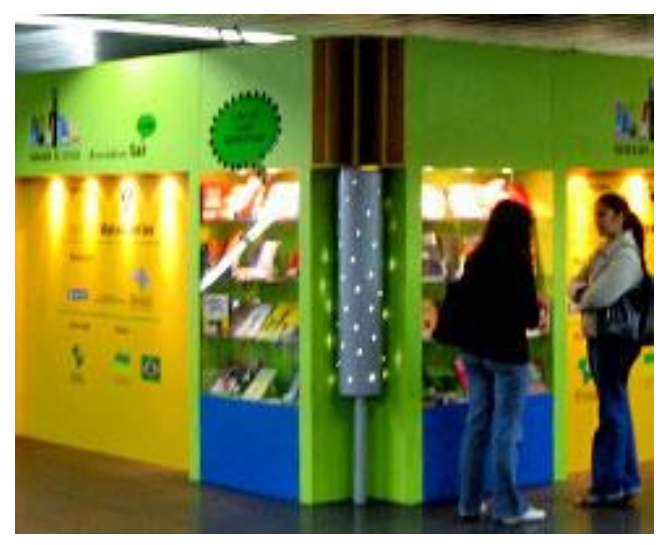

Figura 5: Embarque na Leitura

Cada biblioteca conta com mais de 3.000 títulos que podem ser consultados por meio de um sistema de pesquisa automatizado. Cada unidade funciona separadamente e os sócios têm que devolver os livros nas bibliotecas onde os retiraram. Os livros podem ser emprestados um por vez pelo prazo de 10 dias. 


\section{RIO DE JANEIRO}

\section{Inivos \& Trilhos}

No Rio de Janeiro o projeto recebe o nome Livros \& Trilhos e possuem duas bibliotecas, na Estação Central e Siqueira Campos. A primeira a ser inaugurada foi na Estação Central, em 13 de dezembro de 2006, com um acervo inicial de aproximadamente 2.300 exemplares de diversos autores e títulos, com um universo de livros que vai desde ficção até culinária. Os livros são repostos a cada três meses e os exemplares que apresentarem boas condições são doados a instituições assistenciais. Até dezembro de 2008 foram contabilizados 5.800 sócios que têm acesso aos livros gratuitamente.

Em 2006, ainda na inauguração da Estação Central, William Nacked ${ }^{1}$ afirmou:

O projeto vai ser um sucesso, afinal o carioca gosta de ler. Temos a certeza de que será a primeira de muitas bibliotecas que inauguraremos no Metrô Rio.

Em 26 de novembro de 2007 foi inaugurada a segunda a biblioteca Livros \& Trilhos na Estação Siqueira Campos, em Copacabana. O acervo inicial da nova biblioteca contava com 2.300 livros dos mais diversos estilos: literatura brasileira, auto-ajuda, best-seller, infanto-juvenil, filosofia, religião, ciências sociais, lingüística, artes e história, em pouco mais de um mês já contabilizava 186 sócios inscritos e 245 empréstimos registrados.

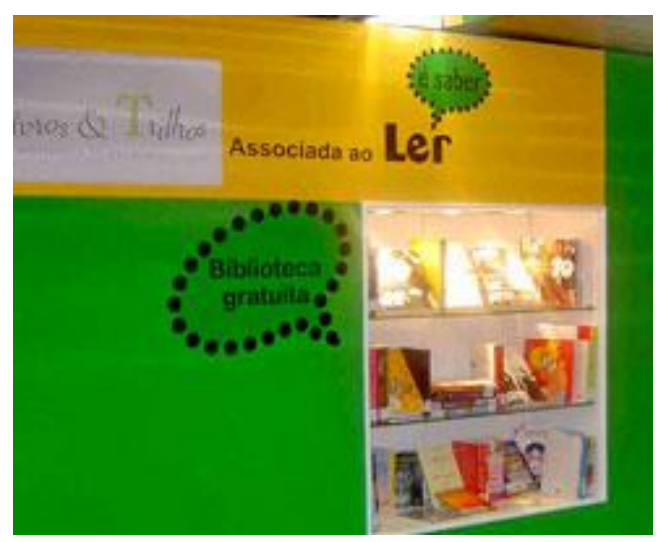

Figura 6: Livros \& Trilhos

\footnotetext{
${ }^{1}$ William Nacked é o Diretor Geral do Instituto Brasil Leitor
} 
A expectativa para o Rio é bastante positiva, como a cidade apresenta os maiores índices de leitura de jornal do país, Regina Amélia²:

No mundo inteiro o que vemos são os usuários do metrô lendo um livro. Isto agora também será possível no metrô do Rio, com esta biblioteca, onde nossos usuários tornando-se sócios poderão retirar gratuitamente os livros de sua escolha e ficar com eles até dez dias.

As Bibliotecas Trilhos \& Livros funcionam de segunda a sexta entre $11 \mathrm{~h}$ e 20h.

\section{PERNAMBUCO}

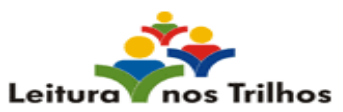

A outra biblioteca é em Recife e se chama Leitura nos Trilhos, ele foi o terceiro sistema de trens a participar desse projeto, depois de São Paulo e Rio de Janeiro.

Foi implantada em 25 de abril de 2007 e contava com mais de dois mil livros em sua inauguração, em seu segundo ano de funcionamento conta com um acervo de 3.026 livros que são disponibilizados para os 3.871 associados, assumindo a postura de incentivadora da cultura, uma vez que oferece empréstimos de livros gratuitamente aos clientes do metrô do Recife. Segundo Valéria Carneiro ${ }^{3}$ :

Os temas dos livros não estão direcionados a um tipo de público específico. Temos, desde temas infantis a livros didáticos e buscamos temas que agradem a todas as faixas etárias. Graças a isso, alcançamos uma média de quase dois mil empréstimos por mês.

A Biblioteca Leitura nos Trilhos funciona de segunda a sexta-feira, das 9 às 20 horas. Os leitores são cadastrados e recebem uma carteirinha de identificação com foto e código de barra para fazer os empréstimos com o

\footnotetext{
${ }^{2}$ Regina Amélia é a Diretora Comercial e de Marketing do Metrô Rio

${ }^{3}$ Valéria Carneiro é Gerente da Biblioteca Leitura nos Trilhos
} 
prazo de dez dias para a devolução. Para Sileno Guedes ${ }^{4}$, o projeto possibilitará o acesso à leitura e novos conhecimentos a um público grande e diversificado:

O Metrô transporta diariamente um grande número de pessoas. É um transporte público que é utilizado por trabalhadores, estudantes e donas de casa, pessoas que necessitam de novos conhecimentos. Com esse projeto podemos tornar acessível, a informação, a toda e qualquer pessoa sem distinção, e assim aprimorar o gosto pela leitura.

O projeto pretende disponibilizar recitais de poesias e músicas. E deve ser ampliado futuramente com a instalação de bibliotecas em outras estações.

\section{RIO GRANDE DO SUL}

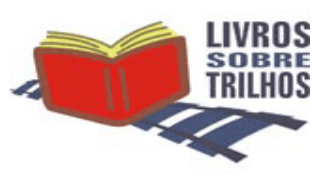

Livro sobre Trilhos é uma nova alternativa de cultura e lazer para os gaúchos. Um estímulo a leitura e combate ao analfabetismo funcional, tanto para os metroviários, quanto para os usuários de trem. Foi pensando nesses benefícios, que em 15 de dezembro de 2008 foi inaugurada a primeira biblioteca metroviária da cidade de Porto Alegre (RS). A Livros sobre Trilhos é localizada na Estação Mercado e conta, assim como as outras unidades, com um acervo inicial de 2.300 livros dos mais diferentes gêneros. Literatura brasileira, auto-ajuda, best-seller, filosofia, religião, ciências sociais, lingüística, artes e história são algumas das opções. A biblioteca também possui uma rica coleção de material infantil, audiobooks e livros em Braille. Cada usuário pode retirar um livro por vez e permanecer com o título durante um período de dez dias, existindo a possibilidade de renovação. Em sua inauguração, Marco Arildo Cunha ${ }^{5}$ afirmou:

\footnotetext{
${ }^{4}$ Sileno Guedes é Superintendente do Metrô de Recife

${ }^{5}$ Marco Arildo Cunha é diretor-presidente da Trensurb
} 
Com a biblioteca na Estação Mercado agregaremos mais um atividade cultural à rotina de nossos usuários, fortalecendo a visão da empresa comprometida com ações na área da responsabilidade socioambiental.

A biblioteca Livros sobre Trilhos da Estação Mercado funcionará de segunda a sexta-feira, das $11 \mathrm{~h}$ às $20 \mathrm{~h}$.

Conforme os dados do IBL, além das do metrô, existem doze bibliotecas em empresas. Quatro em São Paulo: Usina de Leitura, em Cubatão; Máquina do Saber (Caterpillar), em Piracicaba; Engenho do Conhecimento (Usina Colorado), em Guaíra; Luiz E. Kikinger Abreu, em Guarulhos, e Rinaldo Campos Soares, em Taubaté, ambas da empresa Rio Negro. Tem ainda outras duas na cidade de Ipatinga (MG): Central de Idéias no Shopping do Vale do Aço e na Usiminas. E a Angloteca, na Sede da Associação dos Funcionários da Anglo American, em Catalão (GO). Juntas somam mais de 22 mil sócios que pegaram emprestados cerca de 135,5 mil livros. O IBL mantém também 25 unidades das Bibliotecas Primeira Infância, voltada para crianças de até 6 anos. As unidades estão instaladas em Recife (PE), São Paulo, São Joaquim da Barra (SP), Cubatão (SP), Ribeirão Preto (SP), Guará (SP) e Curitiba.

\section{ESTUDO DE CASO: Programa Conte esta História - Mala do Livro}

\subsection{METRÔ - DF}

O METRÔ do Distrito Federal é uma empresa pública responsável pelo planejamento, projeto, construção, operação e manutenção do sistema de transporte público coletivo sobre trilhos no Distrito Federal, e que tem por objetivo garantir a locomoção urbana de seus usuários para que estes possam realizar suas múltiplas atividades: trabalho, lazer, escola, compras, etc.

O Metrô - DF tem como missão oferecer à população um transporte coletivo de qualidade, com eficiência, conforto, limpeza, regularidade, rapidez e segurança, seguindo os preceitos da prevalência do coletivo sobre o individual e da preservação da vida, do meio- ambiente e do patrimônio cultural. 
A história do METRÔ-DF começou em janeiro de 1991, com a criação de um Grupo Executivo de trabalho e a elaboração dos primeiros estudos sobre o impacto ambiental da obra. Em maio daquele ano, foi criada a Coordenadoria Especial, integrada por técnicos de diversas áreas do Governo do Distrito Federal, com a missão de gerenciar a construção do metrô.

Em agosto, foi lançado o edital de concorrência que, posteriormente, classificou o Consórcio Brasmetrô para o fornecimento de bens e serviços necessários à implantação do projeto. As obras foram iniciadas em janeiro de 1992 e, em dezembro de 1993, foi criada a Companhia do Metropolitano do Distrito Federal, com a missão de operar o novo tipo de transporte. Em outubro de 1994, os trabalhos foram paralisados. Dois anos depois, em maio de 1996, as obras foram retomadas.

Em janeiro de 1997, teve início o Programa de Viagens Experimentais, que teve como objetivo apresentar o novo sistema de transporte à população de Brasília. Em julho do mesmo ano, a Companhia do Metropolitano iniciou a convocação dos primeiros concursados, sendo a maioria encaminhada para treinamento no Metrô de São Paulo. De agosto de 1998 a agosto de 1999, o METRÔ-DF operou em regime de operação experimental, destinada a aprimorar o conhecimento prático dos responsáveis pela operação do sistema.

A operação em definitivo do METRÔ-DF teve início em 2001, com a inauguração do trecho que liga Samambaia a Taguatinga, Águas Claras, Guará e Plano Piloto. Em 2006, iniciou-se a operação branca no trecho que liga Taguatinga a Ceilândia Sul, passando pela estação Centro Metropolitano. Em 2007, a operação neste trecho passou a ser comercial. No mesmo ano, recomeçaram as obras para levar o METRÔ-DF até a estação terminal Ceilândia, localizada na Ceilândia Norte.

O ano de 2007 também ficou marcado pela ampliação do sistema metroviário. O horário de funcionamento, das 16 estações operacionais, passou de $6 \mathrm{~h} 00$ às $20 \mathrm{~h} 00$ para $6 \mathrm{~h} 00$ às $23 \mathrm{~h} 30$, o que provocou a ampliação do número de usuários atendidos. No início do ano, eram $45 \mathrm{mil} / \mathrm{dia}$. Ao final, o número alcançou $100 \mathrm{mil} / \mathrm{dia}$, com as estações abertas também aos sábados, domingos e feriados, das $07 \mathrm{~h}$ às $19 \mathrm{~h}$.

As estações em funcionamento do Metrô são: Central, Galeria, 108 Sul, 114 Sul, Asa Sul, Shopping, Feira, Arniqueiras, Águas Claras, Concessionárias, 
Praça do Relógio, Centro Metropolitano, Ceilândia Sul, Guariroba, Ceilândia Centro, Ceilândia Norte, Terminal Ceilândia, Taguatinga Sul, Furnas, Samambaia Sul e Terminal Samambaia. Portanto, o Metrô - DF é composto por 21 estações operacionais e possui uma frota de 20 trens. Ele transporta uma média de 150 mil passageiros ao dia, todos os dias da semana, inclusive aos feriados.

O Metrô - DF forma um sistema troncal de transporte de massa rápido, sobre trilhos, independente, direto, livre do tráfego, capaz de proporcionar aumento significativo da capacidade do transporte à disposição da comunidade em geral, com salto em qualidade e eficiência. Além disso, o Metrô é um exemplo de como a tecnologia pode conviver pacificamente com a natureza, pois os trens são movidos a energia elétrica, não polui e são controlados por um moderno sistema de computadores.

Embora a função primordial do Metrô seja de oferecer ao usuário um serviço do tipo viagem, ele cria a necessidade de outros serviços complementares e de caráter cultural, como:

- Assistencial e de Promoção Humana: atendimento de primeiros socorros a usuários vítimas de acidentes e de males súbitos;

- Utilidade pública: serviços não restritos a usuários do sistema, sendo estendidos à população em geral, como o Posto central de objetos achados e perdidos e delegacia de polícia;

- Canais de Relacionamento e de Comunicação com o usuário: visa a captação de opiniões e reivindicações dos usuários referentes ao sistema Metrô, como o telefone ao usuário, caixas de sugestões e reclamações distribuídas pelas estações, juntamente com painéis, cartazes, panfletos e PA (audição pública) para orientar e informar seus usuários nos diversos aspectos operacionais do sistema.

Anualmente, a Divisão de Atendimento ao Usuário e Ouvidoria realiza pesquisas de opinião. Além da coleta de sugestões e expectativas dos usuários, procura-se conhecer o grau de satisfação dos clientes em relação aos serviços prestados pelo METRÔ-DF. 
As pesquisas também têm como objetivo realizar uma caracterização sócio-econômica dos usuários e conhecer os hábitos de utilização do sistema, verificando o trajeto, o horário, o motivo e a quantidade de viagens realizadas diariamente pelos entrevistados.

Entre novembro e dezembro de 2007 foi realizada a última pesquisa de opinião. Os dados foram coletados do sistema SCAP (Sistema de Controle e Arrecadação de Passageiros) e disponibilizados pela Coordenação de Tratamento da Informação, conforme apresentação a seguir.

De acordo com essa pesquisa, a amostra foi de 381 usuários e o cálculo deste universo tem grau de confiança de $95 \%$, com margem de erro de $5 \%$, e obteve os seguintes resultados:

\section{Faixa Etária}

- A faixa etária dos entrevistados que utilizam o Metrô - DF, em sua maioria $(75,26 \%)$, é de pessoas entre 18 a 40 anos.

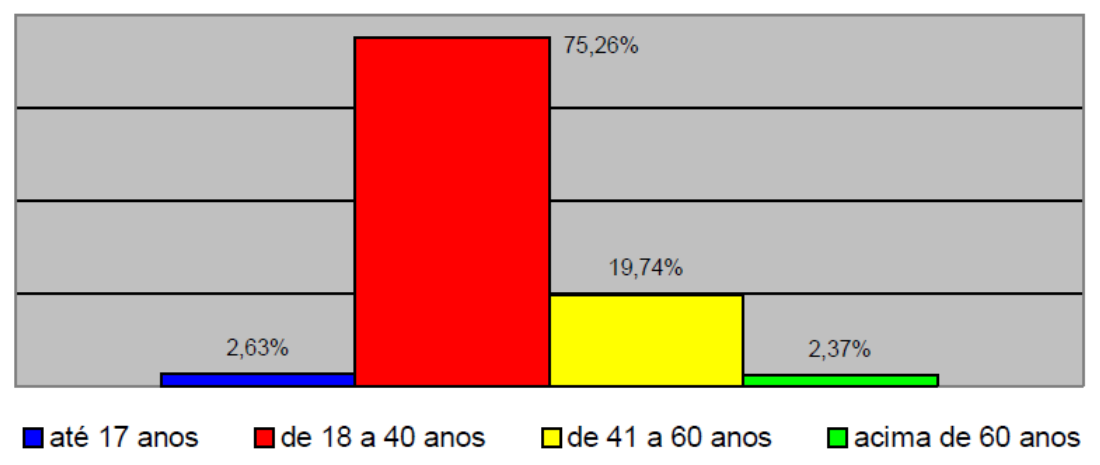

Figura 7: Faixa Etária

\section{Grau de Instrução}

- A maior parte dos entrevistados (42,34\%) possui Ensino Médio completo, conforme a Figura 8: 


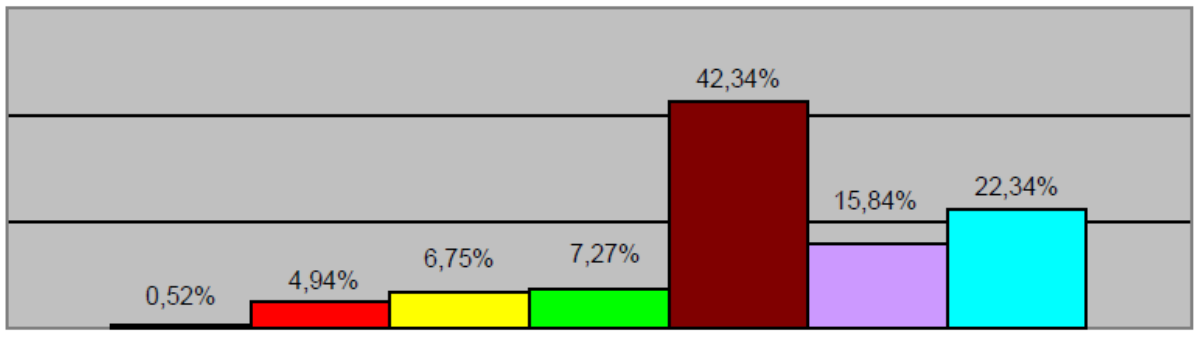

$\square$ sem estudos

$\square$ médio incompleto

$\square$ superior completo

\begin{abstract}
$\square$ fundamental incompleto
$\square$ médio completo

$\square$ fundamental completo $\square$ superior incompleto
\end{abstract}

Figura 8: Grau de Instrução

\section{Renda familiar}

- Quanto à renda familiar, a maioria $(62,33 \%)$ está na faixa intermediária entre $R \$ 760,00$ e $R \$ 3.800,00$, de acordo com a Figura 9:

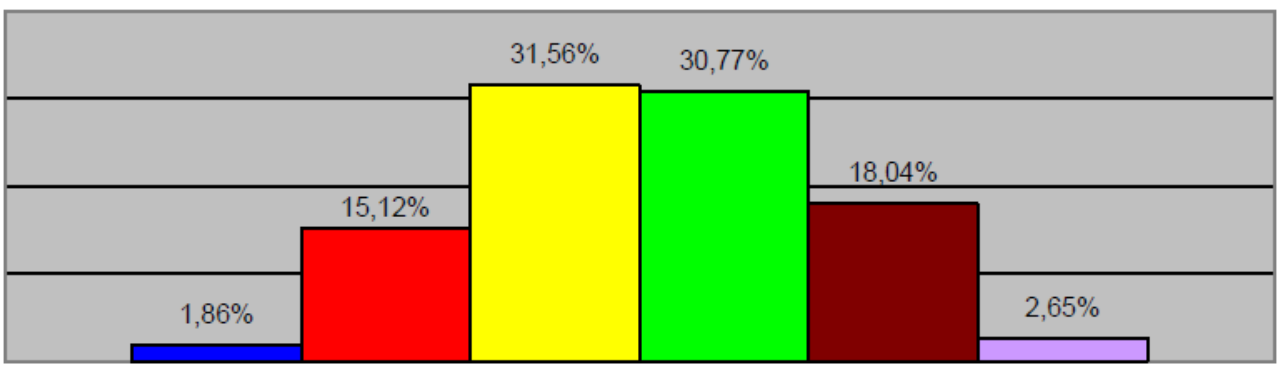

口até $\mathrm{R} \$ 380,00$

口R $\$ 1900,01$ a $R \$ 3800,00$
口R $\$ 380,01$ a $R \$ 760,00$

口R $\$ 3800,01$ a $R \$ 7600,00$ $\square \mathrm{R} \$ 760,01$ a $\mathrm{R} \$ 1900,00$ $\square$ acima de $\mathrm{R} \$ 7600,01$

Figura 9: Renda Familiar

\section{Motivo da Viagem}

- A maioria dos usuários $(71,4 \%)$ utiliza o METRÔ-DF para se deslocar para o trabalho, usando os serviços, em geral, de segunda à sexta-feira, conforme Figura 10: 


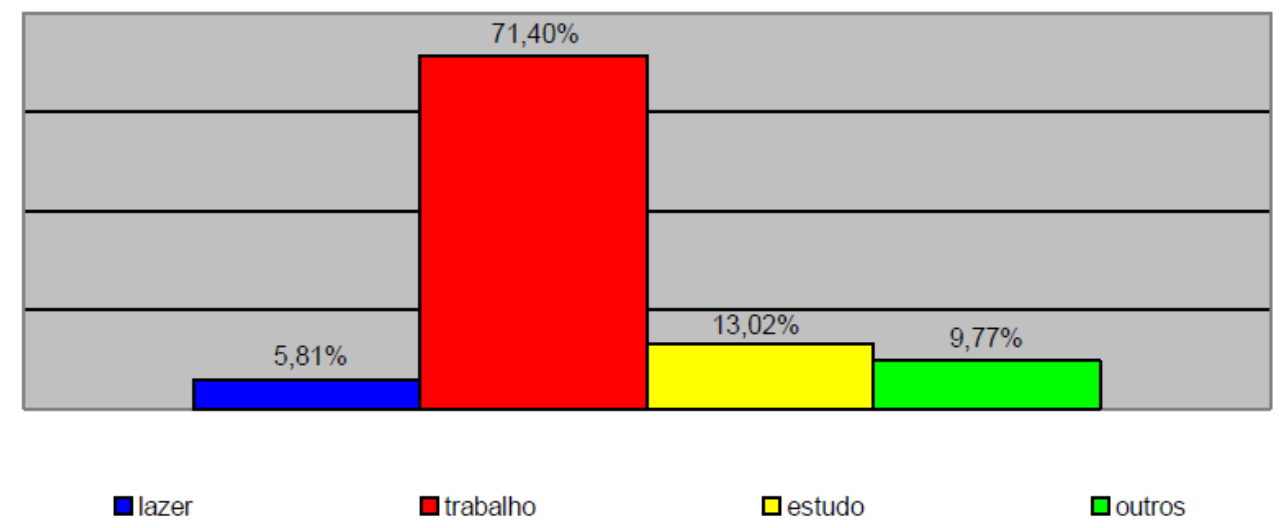

Figura 10: Motivo da viagem

\section{Comunicação sonora nas Estações}

- A maioria dos usuários $(51,58 \%)$ considera "bom" a comunicação sonora nas estações, porém, o alto índice dos que julgam a comunicação sonora nas estações e trens como regular $(26,31 \%)$ pressupõe a necessidade de melhorias no sistema e treinamento dos empregados, conforme Figura 11:

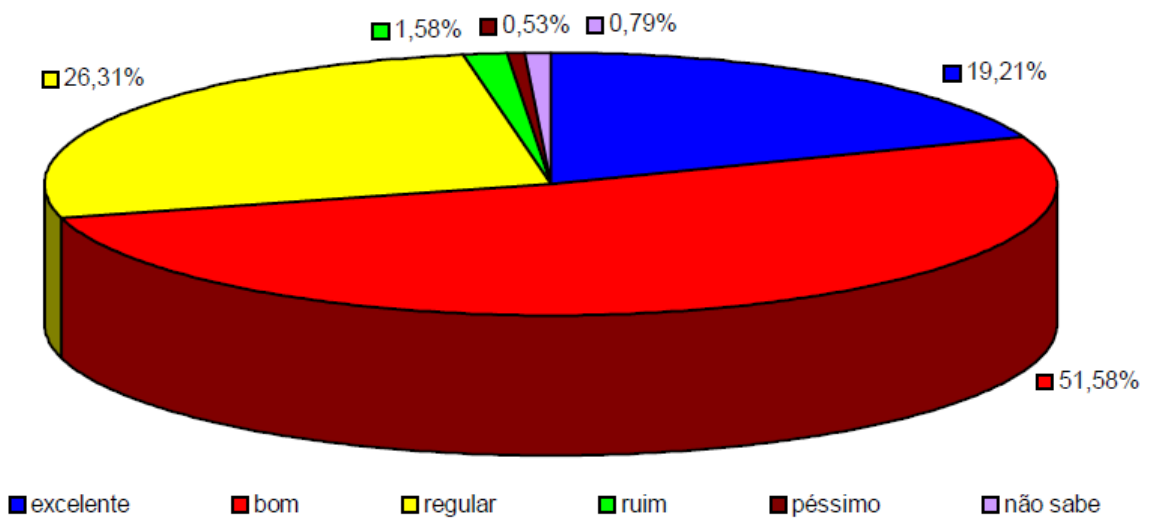

Figura 11: Comunicação Sonora das Estações 


\section{Limpeza e Conservação das estações}

- Verifica-se que a limpeza e conservação das estações são bem vistas pelos usuários, pois grande parte a julgam como excelente $(41,45 \%)$, segundo Figura 12:

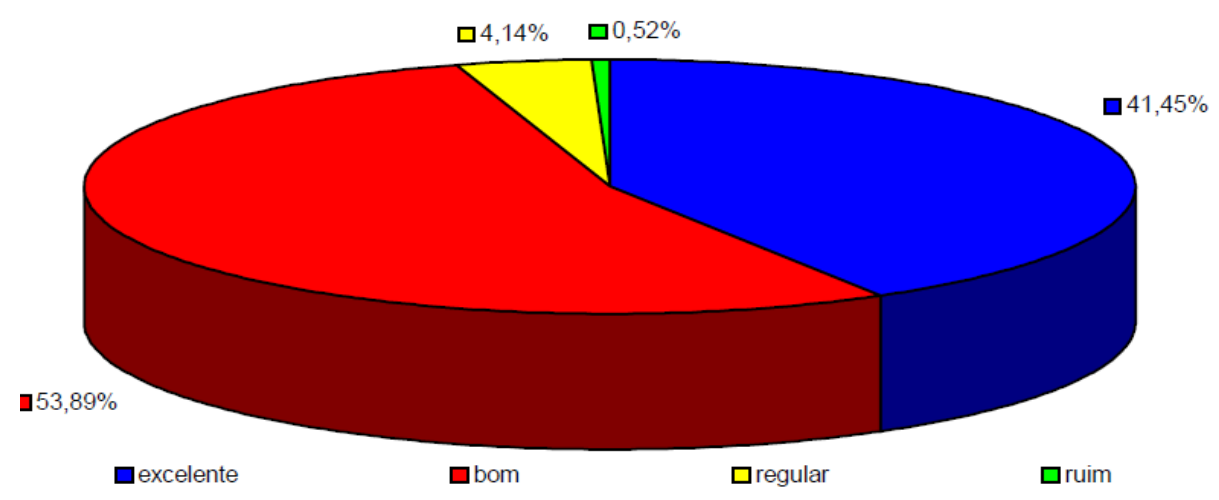

Figura 12: Limpeza e Conservação das Estações

\section{Tempo de Espera na Bilheteria}

- Apesar da percentagem de usuários que consideram o tempo de espera na bilheteria como bom estar de acordo com a média (51,04\%), aqueles que julgam como regular, ruim e péssimo está alto, o que reforça a necessidade de melhorias no sistema de bilhetagem da Companhia, conforme Figura 13:

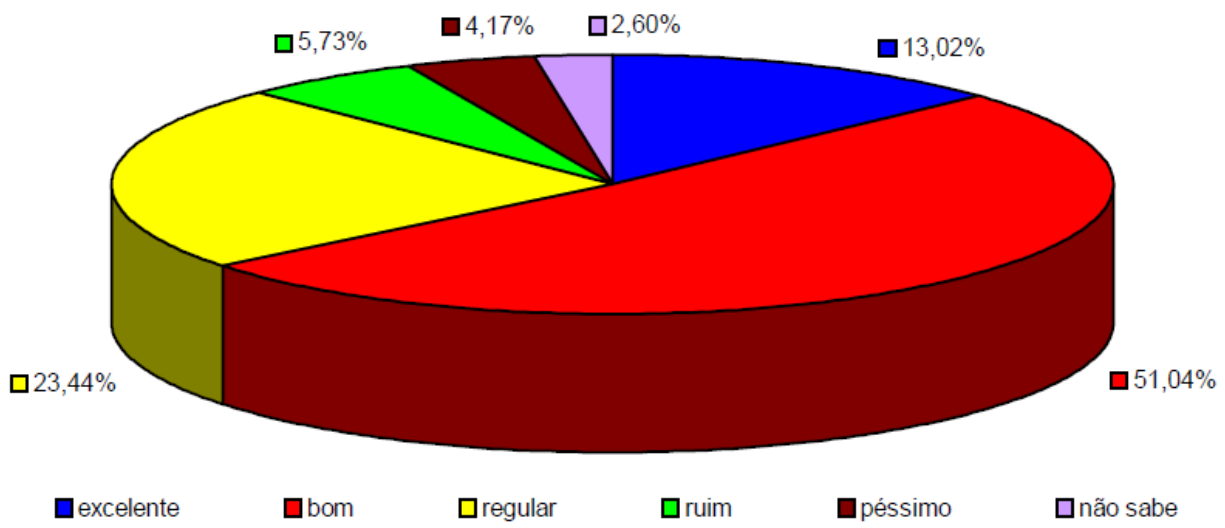

Figura 13: Tempo de espera na Bilheteria 


\section{Tempo de Viagem}

- Quanto ao tempo de viagem, a maioria $(60,84 \%)$ considera bom, conforme Figura 14:

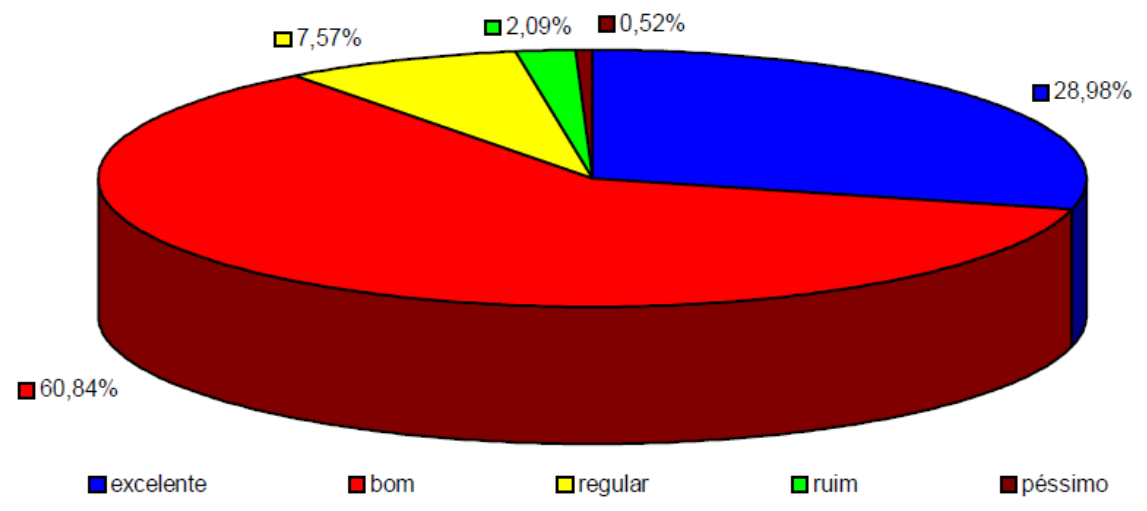

Figura 14: Tempo de Viagem

\section{Segurança no Sistema}

- De acordo com as respostas, a maioria $(58,53 \%)$ considera "bom" a segurança no Sistema, constituindo um dos pontos fortes do Metrô - DF, segundo a Figura 15:

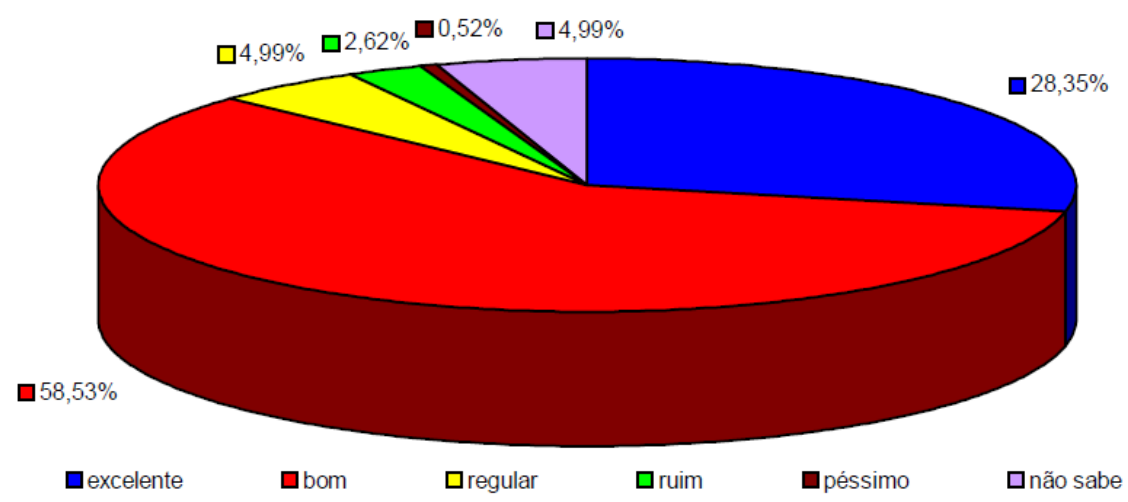

Figura 15: Segurança no Sistema 


\section{Clareza das Informações}

- Verifica-se que o atendimento dispensado pelos empregados da companhia, no que se refere à cordialidade e a clareza das informações prestadas, são outros destaques no serviço oferecido à população, conforme a Figura 16 , onde a maioria $(60,63 \%)$ respondeu como "bom":

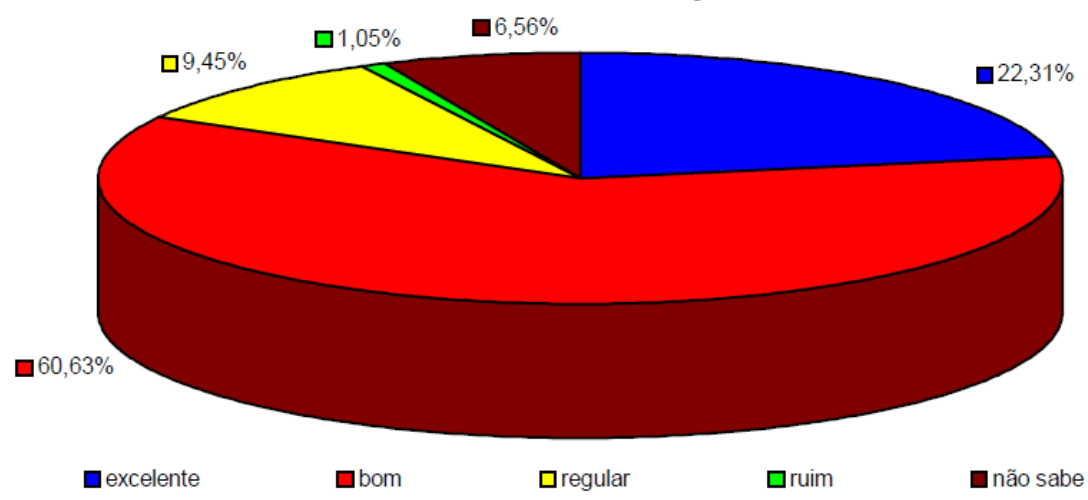

Figura 16: Clareza das Informações

\section{Avaliação dos Serviços}

- Mais de 95\% dos usuários consideram o serviço excelente ou bom, valor acima da média de $71,77 \%$, nas questões onde foi solicitado aos usuários uma valoração para cada item. Isso pode ser explicado pelo fato do quesito mensurar o grau de satisfação do serviço como um todo, sem a preocupação com os pontos a serem corrigidos ou reforçados, conforme os resultados apresentados na Figura 17: 


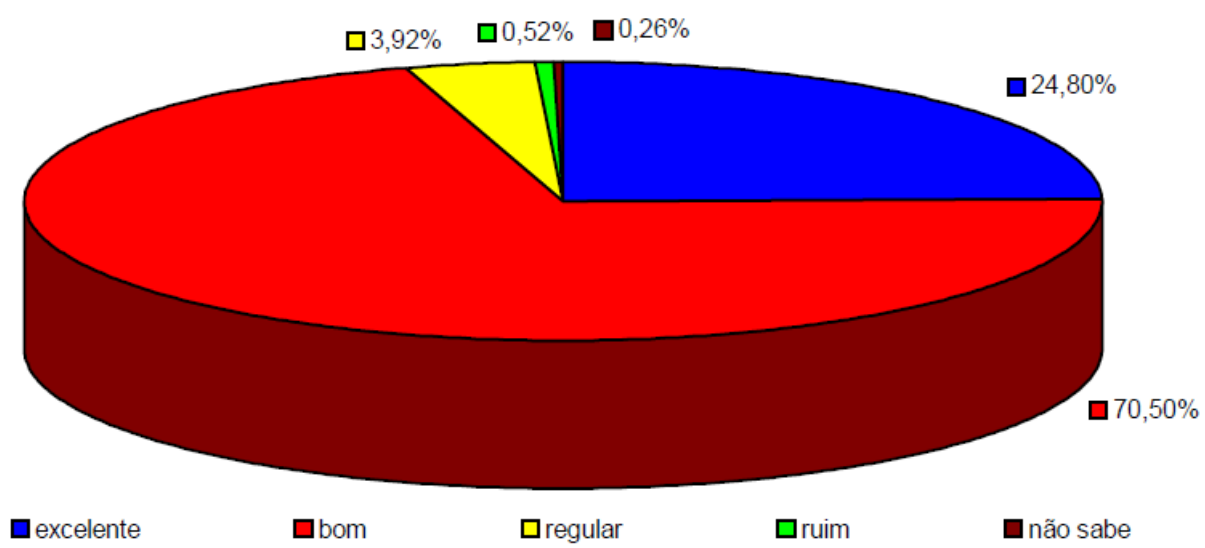

Figura 17: Avaliação do Serviço do Metrô - DF

Essa pesquisa contribuiu para o estabelecimento de um conceito e conhecimento da Companhia do Metropolitano do Distrito Federal, bem como um referencial para essa monografia.

\subsection{SECRETARIA DE CULTURA DO DF}

A Secretaria de Cultura é um órgão da estrutura administrativa do Governo do Distrito Federal, de acordo com o seu site, é responsável pela articulação e coordenação da política cultural do Distrito Federal, e tem por competências básicas:

- Criar, manter, preservar, estimular e apoiar direta e/ou indiretamente bibliotecas, centros de ação cultural, museus, arquivos, teatros, salas de espetáculos, orquestras, coros, cinemas e outros afins relacionados à área de cultura;

- Formular e executar a política cultural do Distrito Federal;

- Incentivar a produção cultural do Distrito Federal, por meio do Fundo de Arte e da Cultura (FAC);

- Incentivar os programas de valorização e profissionalização dos artistas e técnicos do Distrito Federal;

- Promover e incentivar festivais, seminários, temporadas e programas de intercâmbio cultural, artístico e científico; 
- Promover, apoiar, e patrocinar eventos de cunho artístico e cultural da cidade e Região Integrada de Desenvolvimento do Entorno;

- Programar, coordenar, organizar, executar e fiscalizar anualmente o Festival de Brasília do Cinema Brasileiro, direta ou indiretamente;

- Adquirir, arrendar, manter ou administrar teatros, cinemas, galerias, museus, bibliotecas, orquestras, sala de espetáculos e outros espaços de apresentações culturais.

A sua estrutura conta com três Subsecretarias, onde se localiza a Diretoria de Bibliotecas, conforme organograma apresentado na Figura 18:

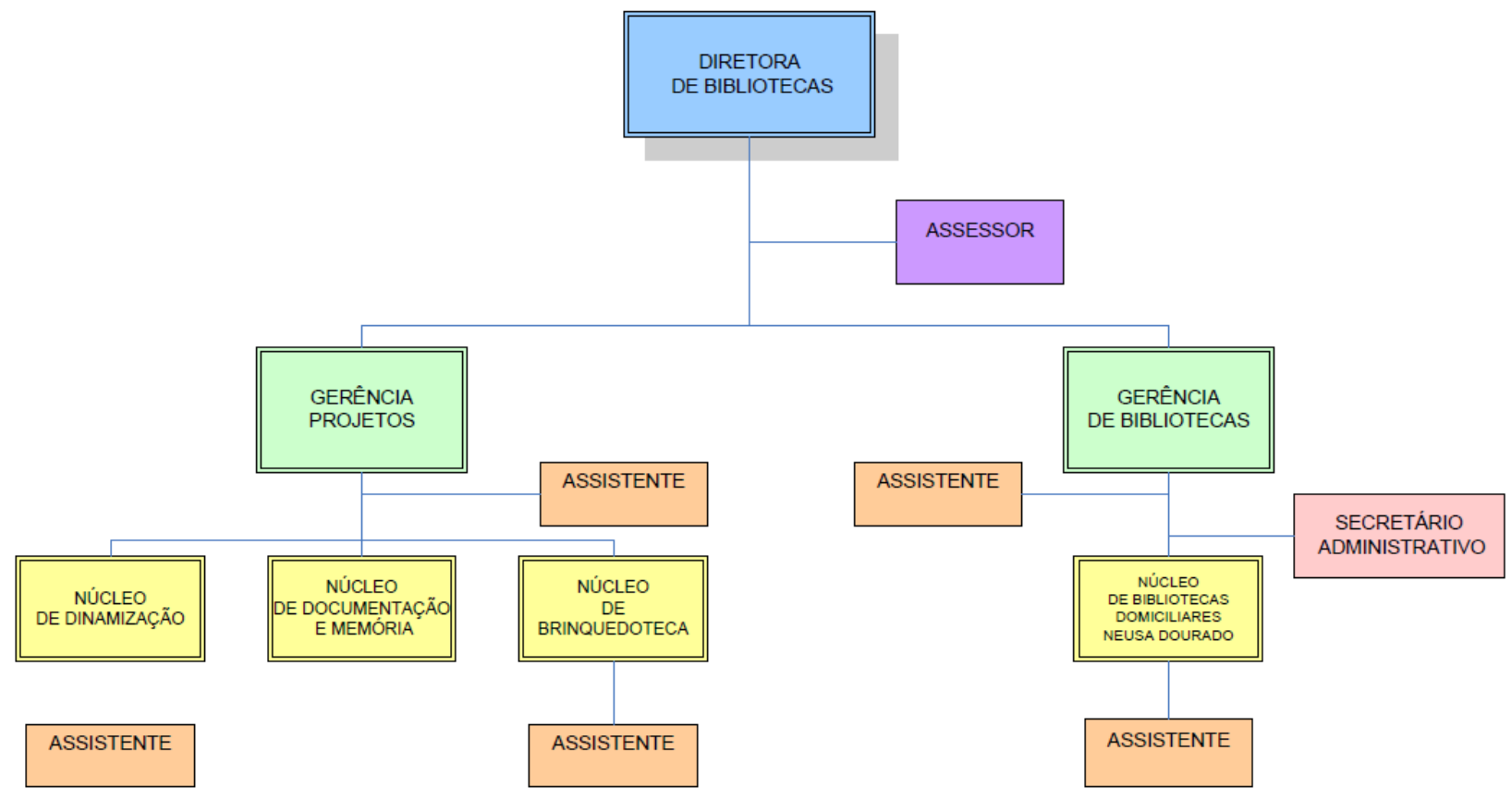

Fonte: site da Secretaria de Cultura, 2009.

Figura 18: Organograma da Diretoria de Bibliotecas

A Diretoria de Bibliotecas, por meio do Núcleo de Dinamização, desenvolve várias atividades culturais nas bibliotecas públicas do Distrito Federal, com o objetivo de tornar estes espaços cada vez mais acolhedores e incentivadores da leitura e da aprendizagem. Entre essas atividades, destacam-se as oficinas gratuitas destinadas ao público em geral, saraus literários e shows, exposições itinerantes e peças teatrais. O Núcleo de Dinamização é um programa da Rede de Bibliotecas Públicas do Distrito 
Federal que promove ações visando incrementar a circulação de bens culturais, socialização de idéias e experiências das Bibliotecas, através de apresentações teatrais, exposições, oficinas vivenciais e projetos literários.

A Secretaria conta também com o Fundo de Apoio à Cultura (FAC), que busca apoiar projetos nas diversas áreas culturais, como dança, teatro, folclore, artesanato, cinema e vídeo, fotografia, literatura, música, artes plásticas, e patrimônio histórico. O retorno dos projetos apoiados à comunidade do Distrito Federal se dá por meio das contrapartidas oferecidas em cada projeto. Quando é editado um livro, um percentual destes exemplares é destinado às bibliotecas públicas do DF; quando da edição de um CD, os artistas realizam, no mínimo, três apresentações gratuitas em instituições e espaços comunitários.

A Secretaria atualmente apóia alguns projetos de grande repercussão cultural. São eles: Orquestra Sinfônica de Brasília, Museu Nacional, Cultura nas Cidades, Festival de Brasília do Cinema Brasileiro e Mala do Livro.

Cumpre à Secretaria de Cultura a responsabilidade pela orientação técnica de todas as Bibliotecas Públicas existentes nas 19 Regiões Administrativas do DF, bem como despertar o interesse do cidadão para a pesquisa, leitura e utilização dos espaços. As Bibliotecas das Regiões Administrativas foram dinamizadas oferecendo, além dos serviços tradicionais, oficinas de origami, papel reciclado, contador de histórias, apresentações de peças teatrais e outras. Para tanto, a Secretaria de Cultura conta com 21 bibliotecas públicas no Distrito Federal, além de cinco brinquedotecas e projetos como a Mala do Livro. Tudo isso coordenado pela Diretoria de Bibliotecas da Secretaria de Cultura.

\subsection{PROGRAMA MALA DO LIVRO}

O Programa Mala do Livro é voltado à criança, ao adolescente e ao adulto, visando facilitar o acesso à informação e à leitura. Ele está inserido no conjunto de políticas públicas promovidas pelo Governo do Distrito Federal para democratizar o livro e aprimorar o índice de leitura do DF, visto que a 
popularização da leitura e do uso do livro é um processo fundamental da construção da cidadania e do desenvolvimento sócio cultural das comunidades.

O programa coordena ações que promovem a leitura em comunidades de pouco ou nenhum acesso a bibliotecas públicas e tem como base minibibliotecas residenciais instaladas em caixas-estantes de madeira que comportam até 200 livros, entre volumes literários, material didático, revistas, dicionários, enciclopédias e gramáticas. É coordenado pela Diretoria de Bibliotecas da Secretaria de Cultura do GDF e configura-se como um serviço de extensão das Bibliotecas Públicas.

O Programa Mala do Livro foi iniciado em 1990, quando a bibliotecária Neusa Dourado, da Secretaria de Cultura do Distrito Federal, embasada no trabalho desenvolvido por uma bibliotecária francesa, deixou sacolas de livros com algumas donas de casa na cidade de Samambaia, as quais controlavam o empréstimo e a devolução. Desta forma, as pessoas, apesar de morarem distantes da Biblioteca Pública, tinham acesso à leitura. A idéia tomou força em 1993 e as nove sacolas, substituídas por caixas-estantes, aumentaram para 70 , sendo estendidas a outras cidades.

As bibliotecas domiciliares tornaram-se pólos irradiadores de cultura, atraindo principalmente crianças e adolescentes. Sem precisar sair de sua comunidade, elas descobrem o prazer de ler e contar histórias, orientadas por um Agente Comunitário da Leitura, pessoa que, voluntariamente, coloca sua residência e seu tempo à disposição do programa. Em 1996, o Programa de Extensão Bibliotecária, denominado Programa Mala do Livro: Biblioteca Domiciliar Neusa Dourado, foi instituído por decreto oficial, sob responsabilidade da Secretaria de Estado de Cultura. Atualmente conta com 543 Malas espalhadas em todas as Cidades Satélites e entorno, além da Zona Rural. O Mala do Livro existe também fora dos domicílios: em hospitais, casas abrigos, restaurantes comunitários, SOS Criança, Zoológico, Embrapa e no Metrô.

Os livros do acervo são adquiridos por intermédio de campanhas de doações junto à comunidade, por doação direta de pessoa física ou jurídica e por um processo especial de compra denominado "rubrica de material para distribuição". 
A classificação dos livros não é feita de acordo com os padrões tradicionais usados em bibliotecas. A fim de facilitar o arranjo do acervo, convencionou-se o uso das cores para diferenciar os assuntos e substituir a classificação, facilitando a recolocação do livro no lugar de origem, visto que os agentes voluntários teriam dificuldades sem a ajuda desse identificador. Cada material recebe um adesivo circular colorido que determina o assunto ou tipo de obra, assim convencionado:

- Verde: livros de pesquisa, estudo, pastas, envelopes;

- Branco: literatura infantil e juvenil, jogos, brinquedos;

- Amarelo: literatura brasileira;

- Azul: literatura estrangeira.

O empréstimo de livros tem validade de sete dias e pode ser renovado caso o volume não tenha sido reservado por outra pessoa. Para se cadastrar como leitor, basta preencher ficha de inscrição na Biblioteca Domiciliar mais próxima. Já o cadastramento dos agentes deve ser feito na Diretoria de Bibliotecas Públicas, localizada na Secretaria de Cultura do Distrito Federal.

O programa tem parceiros como o Laboratório Sabin, que nos últimos três anos doou aproximadamente 19 mil livros por meio do Projeto Conte essa História, baseado em campanhas anuais de arrecadação entre clientes, colaboradores e fornecedores do laboratório. Em 2005, as obras foram entregues no dia 24 abril, no lançamento do projeto "Tenda da Leitura - Venha Ler no Parque", da Secretaria de Cultura.

Para garantir o cumprimento das metas, a coordenação da Mala do Livro renova os acervos de acordo com as necessidades de cada comunidade, promove cursos de capacitação dos Agentes Comunitários da Leitura e organiza atividades culturais para estreitar as formas de interação com o livro e com outras manifestações culturais como teatro, música, artesanato, debates, torneios e mostra de vídeos.

Hoje, com 19 anos de existência, o Mala do Livro conta com um acervo de 85.350 livros, atingiu 602.400 leitores e teve 1.807 .200 empréstimos. 


\subsection{PROJETO CONTE ESTA HISTÓRIA}

Trata-se de uma parceria entre a Secretaria de Estado de Cultura com o Instituto Sabin e o Metrô/DF que visa estender o Programa Mala do Livro para as estações do Metrô de forma a oferecer a população do Distrito Federal o acesso aos livros que são doados ao Programa. É também chamado de Ponto de Leitura.

O Instituto Sabin instala a estrutura e a Secretaria de Cultura disponibiliza os livros para a população e usuários do Metrô. Os livros são adquiridos por meio de doação da comunidade e o Instituto Sabin realiza anualmente campanhas de arrecadação de livros, que já renderam mais de 62 mil exemplares. Os livros podem ser entregues no próprio estande da estação ou pode ser solicitado para que agentes do Programa os busquem em casa, conforme Figura 19:

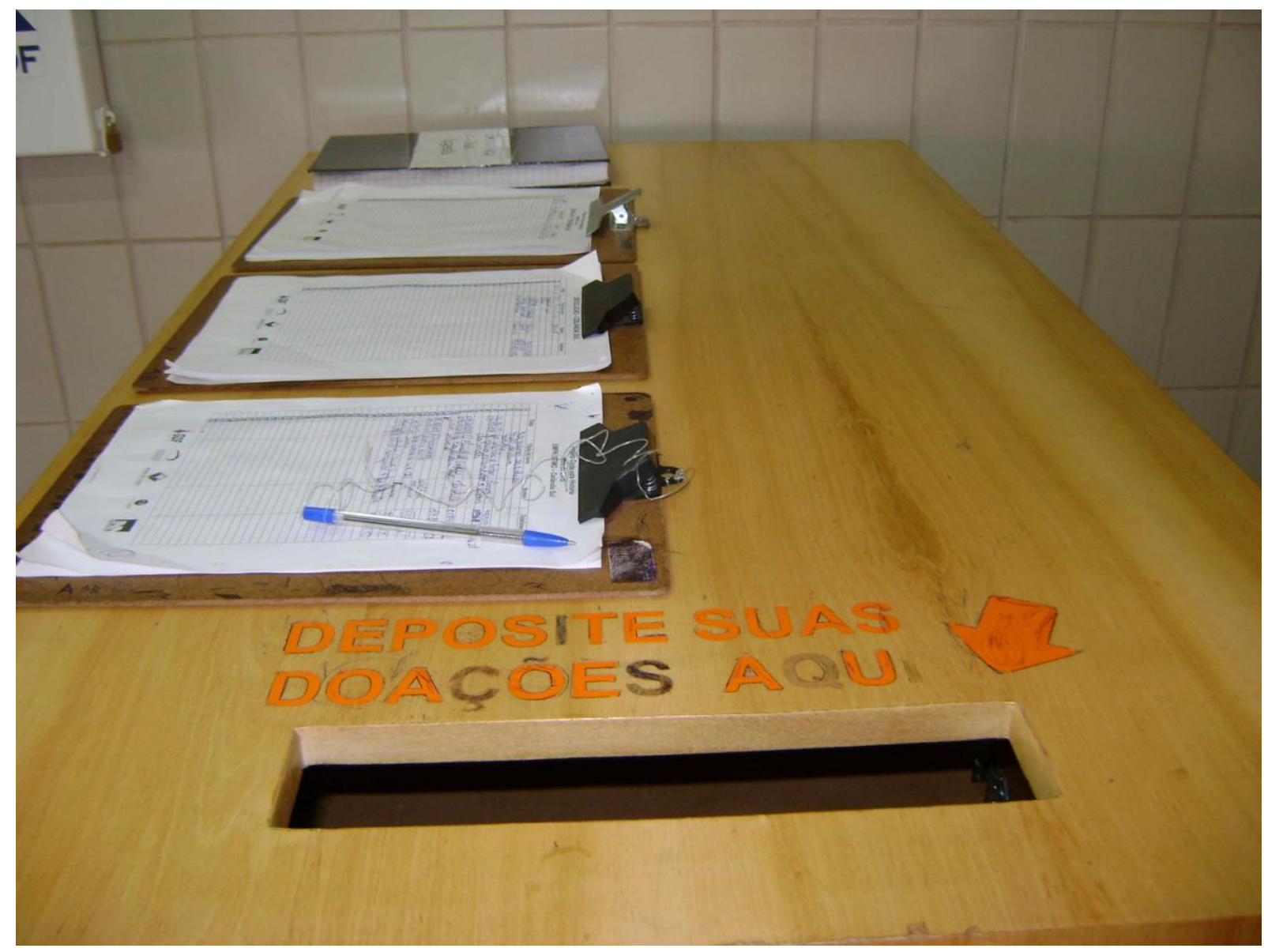

Figura 19: Baú para Doação 
No estande do projeto existem três formulários: um para o empréstimo, um para a devolução e outro para as doações. O Próprio usuário pega o livro, se identifica e assina a ficha de empréstimo. O prazo para entrega é de 20 dias e o livro pode ser devolvido em qualquer unidade do projeto Conte esta História. Para facilitar a organização do acervo e a identificação dos livros pelos usuários, a classificação é semelhante à da Mala do Livro. Um adesivo é colado na lombada dos livros com cores para sua identificação:

- Vermelho: literatura brasileira

- Verde: assuntos gerais

- Amarelo: infantil

- Azul: literatura estrangeira

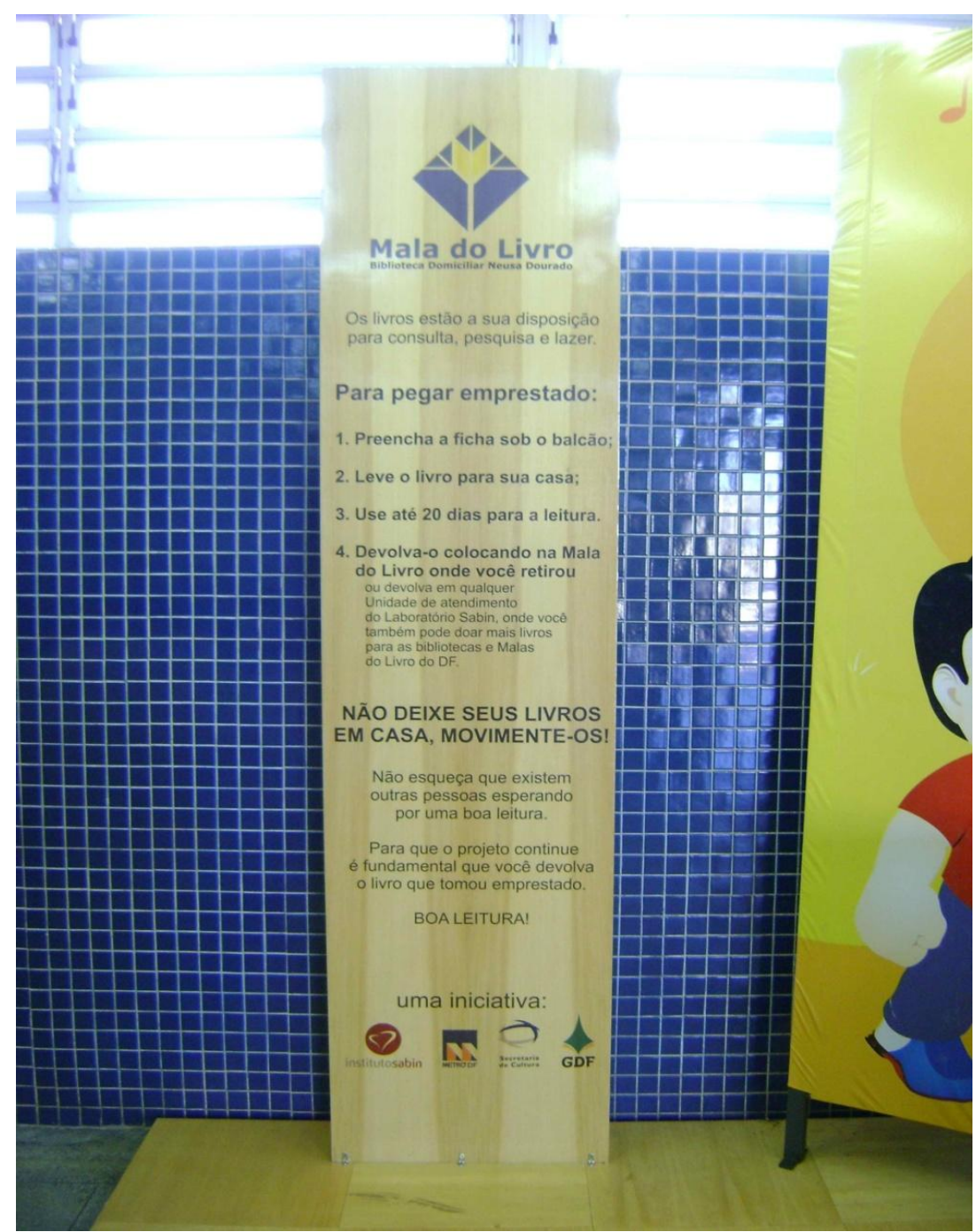

Figura 20: Totem de orientação para o usuário 
O Projeto possui 1 ano e 3 meses de existência e seu primeiro estande foi instalado em março de 2008 na Estação Central (Rodoviária do Plano Piloto). Depois se estendeu para mais nove estações: Galeria, 108 sul, Feira, Águas Claras, Praça do Relógio, Ceilândia Sul, Guariroba, Ceilândia Norte e Furnas.

Algumas dessas estações são Estações Temáticas, contendo particularidades. A da Estação Ceilândia Sul recebe o nome de "Estação Casa do Cantador", em homenagem a grande parte de nordestinos e descendentes residentes na cidade em que parte do acervo é formado por cordéis. Foi feita uma parceria com a Casa do Cantador, que é uma casa de cultura nordestina perto da estação, em que eles disponibilizam cordéis para o projeto, como ilustrado na figura 21 :

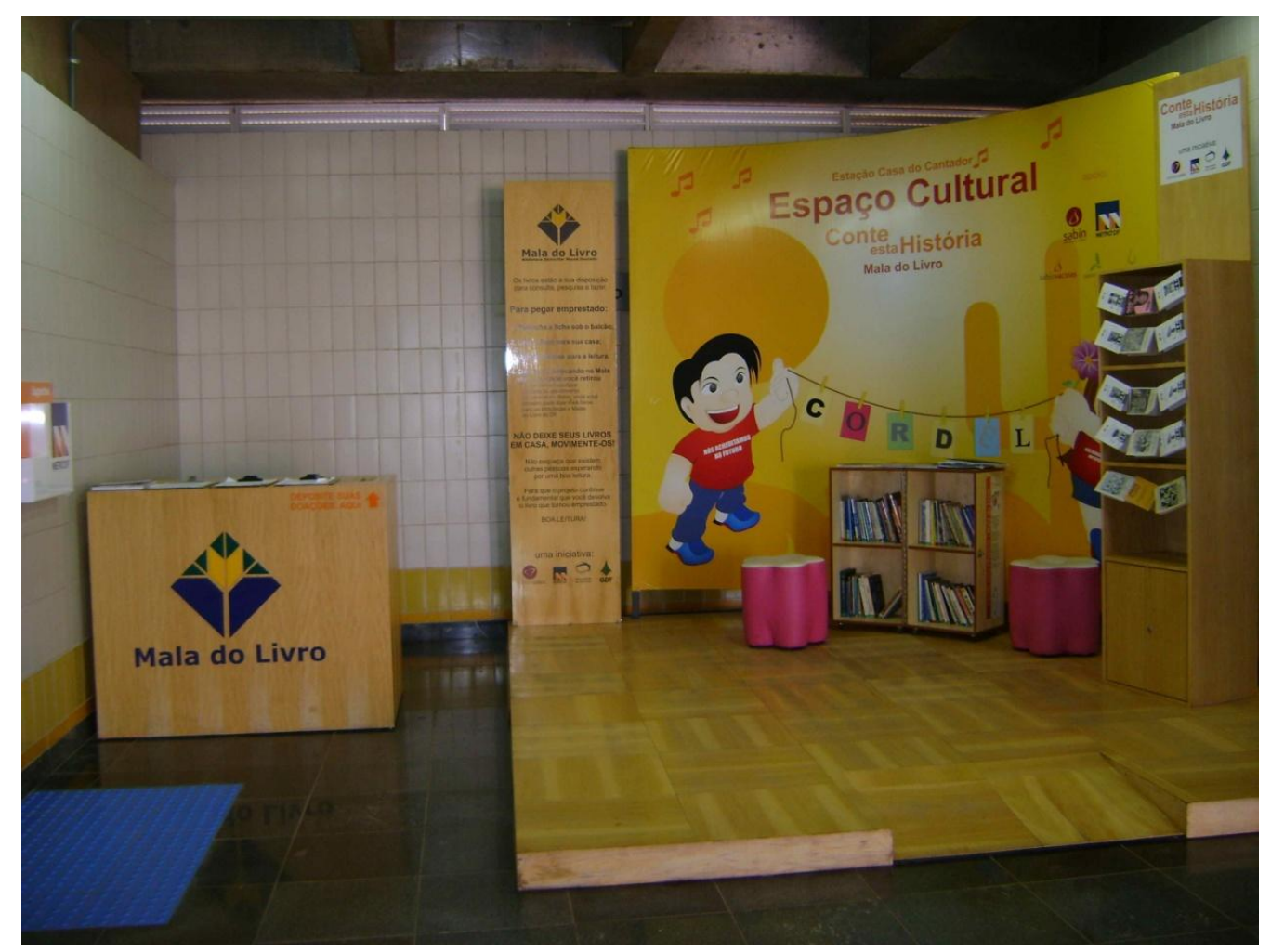

Figura 21: Estação "Casa do Cantador"

Estação 108 Sul é a Estação "Escritores de Brasília" em homenagem aos pensadores da cidade. 


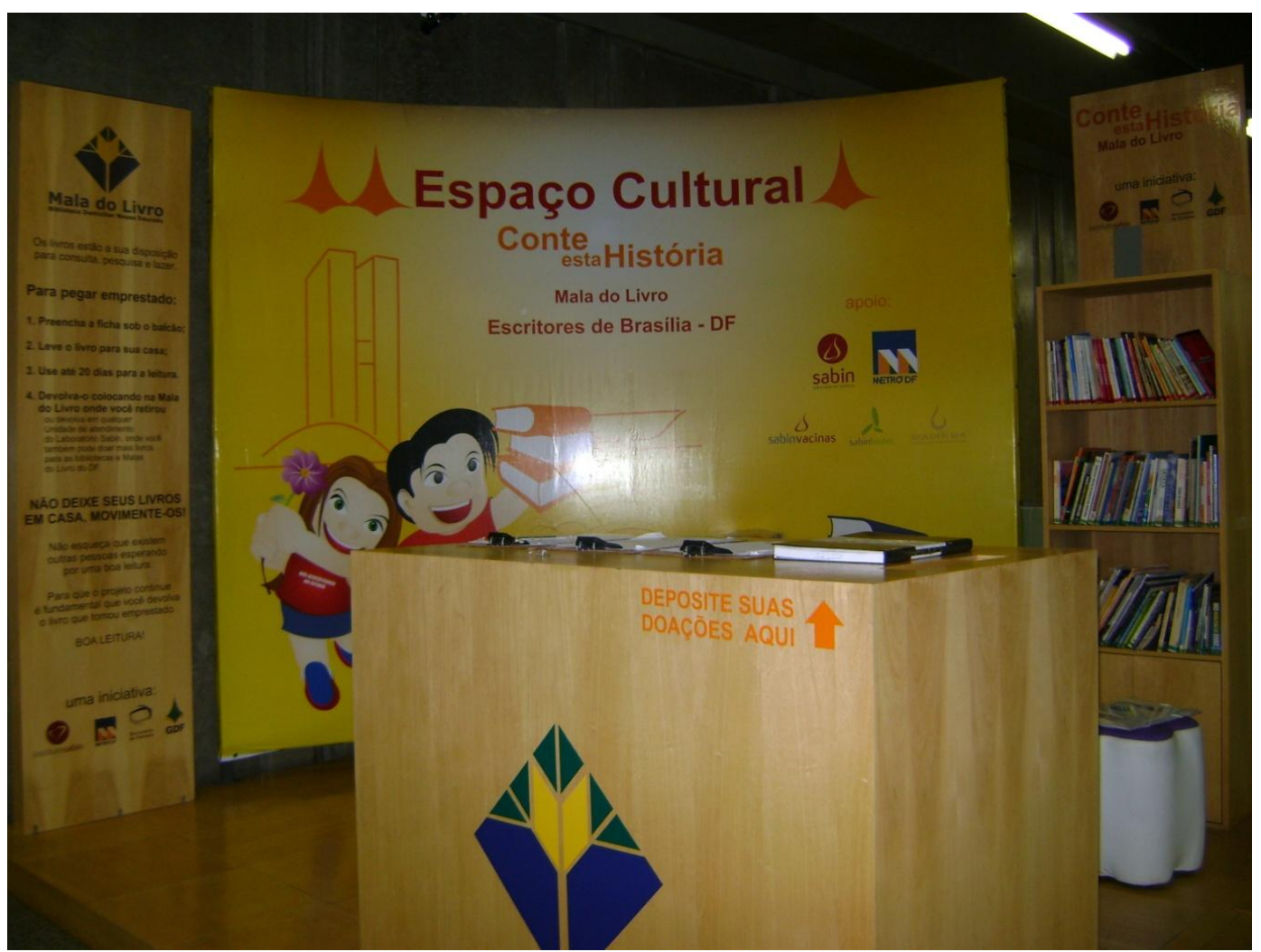

Figura 22: Estação "Escritores de Brasília"

E a Estação Águas Claras recebe o nome de "Estação Meio Ambiente" pois o espaço tem como tema o Meio Ambiente e conta com livros direcionados para o assunto e tem o apoio da Agência Nacional das Águas.

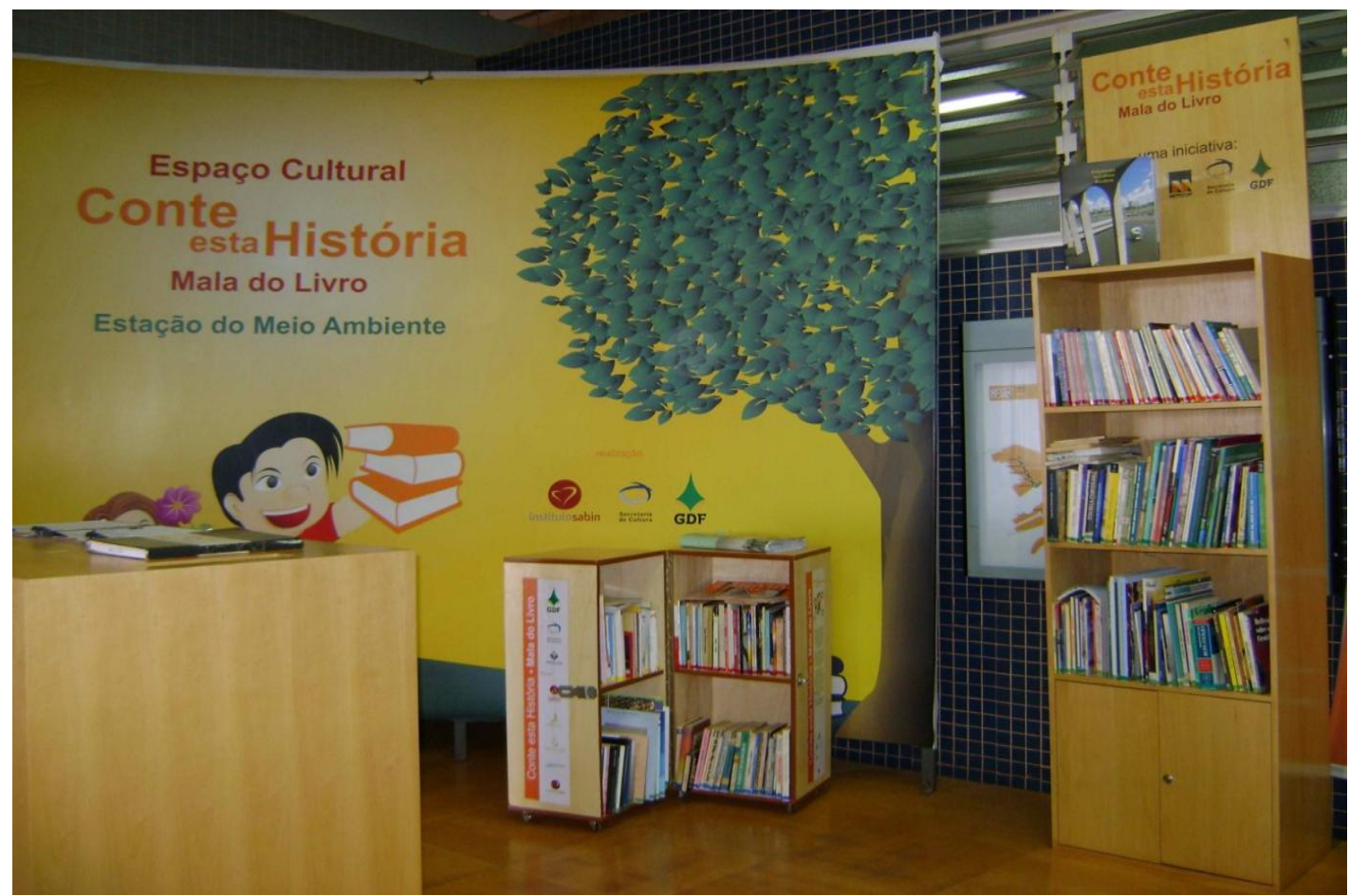

Figura 23: Estação "Meio Ambiente" 
O programa conta ainda com uma parceria com a Biblioteca Braile, que disponibiliza livros em braile para os portadores de necessidades especiais.

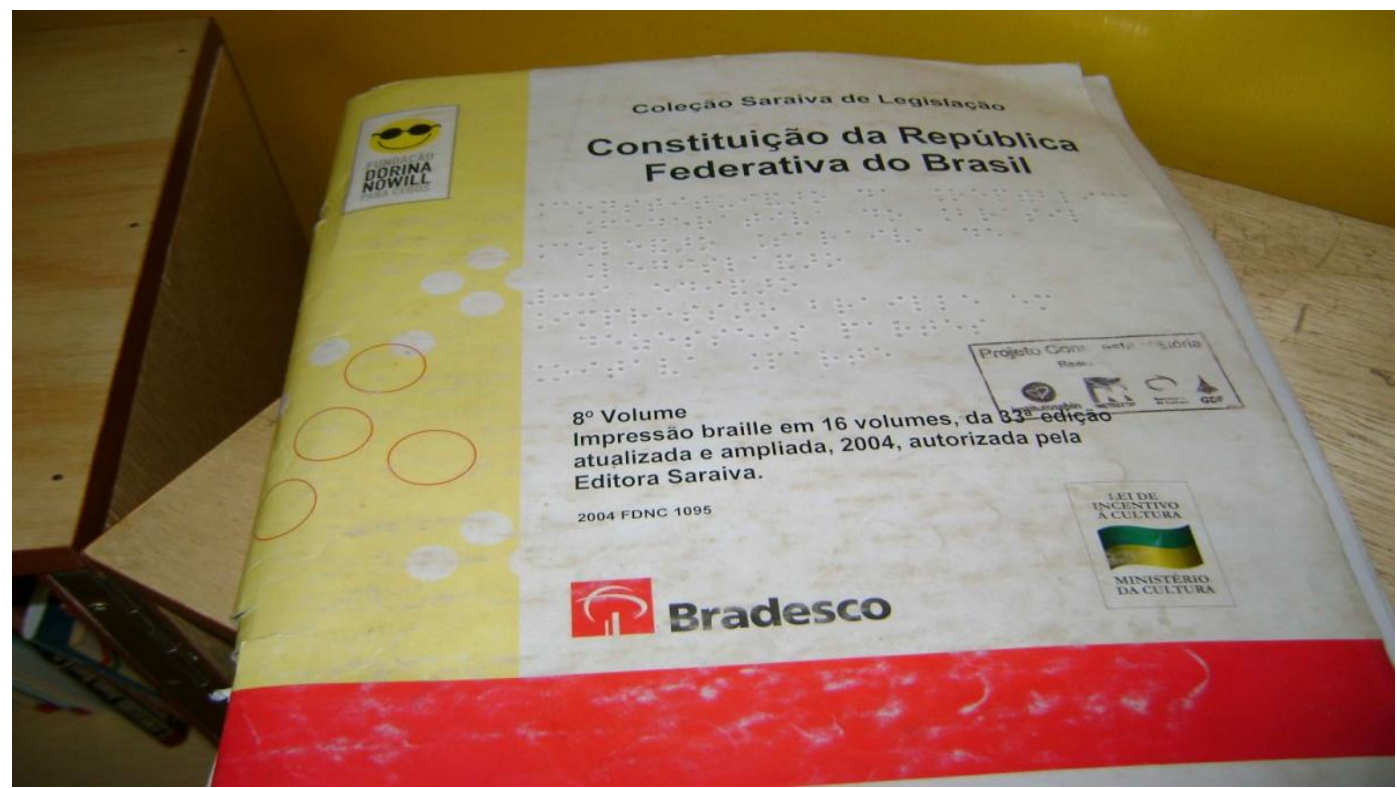

Figura 24: Livro em Braile

O horário de funcionamento do projeto depende do funcionamento do Metrô, que é de segunda à sexta, das 6:00 às 23:30, e aos sábados, domingos e feriados das 7:00 às 19:00.

O Mala do Livro no metrô conta com 8 funcionários que passam diariamente em cada estação para arrumar o estande, repor livros no acervo e recolher as doações.

Hoje, o principal problema do projeto é a falta de funcionários para auxiliar a população a respeito do funcionamento do programa. A Diretoria de Bibliotecas já entrou em contato com o Metrô - DF para ver a possibilidade deste ceder um funcionário para a realização do serviço. Porém, essa parceria não foi feita pela indisponibilidade de pessoal.

O Projeto Conte Esta História já ajudou muita gente que não tinha nenhum acesso à leitura, por ser um espaço democrático onde qualquer pessoa pode pegar livros sem nenhuma burocracia. 


\subsubsection{Acesso e Uso do Projeto}

A Diretoria de Bibliotecas realiza mensalmente estatísticas sobre o uso do programa, o que sempre corrobora para a continuidade do mesmo. A seguir estão as estatísticas realizadas no ano de 2008 e 2009, de acordo com as tabelas 1 e 2 :

\section{Tabela 1: Estatísticas de uso do Conte esta História 2008}

\begin{tabular}{|c|c|c|c|c|c|c|c|c|c|}
\hline \multicolumn{10}{|c|}{ ABRIL } \\
\hline & Central & 108 Sul & Guariroba & $\begin{array}{l}\text { Ceilândia } \\
\text { Sul }\end{array}$ & $\begin{array}{l}\text { Ceilândia } \\
\text { Norte }\end{array}$ & $\begin{array}{l}\text { Praça do } \\
\text { Relógio }\end{array}$ & $\begin{array}{l}\text { Águas } \\
\text { Claras }\end{array}$ & Samambaia & Total \\
\hline Empréstimo & 1929 & 363 & 210 & & 255 & & & & 2757 \\
\hline Devolução & 665 & 73 & 66 & & 86 & & & & 890 \\
\hline Doação & 157 & 42 & 21 & & 200 & & & & 420 \\
\hline \multicolumn{10}{|c|}{ MAIO } \\
\hline & Central & 108 Sul & Guariroba & $\begin{array}{l}\text { Ceilândia } \\
\text { Sul }\end{array}$ & $\begin{array}{l}\text { Ceilândia } \\
\text { Norte }\end{array}$ & $\begin{array}{l}\text { Praça do } \\
\text { Relógio }\end{array}$ & $\begin{array}{l}\text { Águas } \\
\text { Claras }\end{array}$ & Samambaia & Total \\
\hline Empréstimo & 1437 & 242 & 356 & 51 & 251 & 100 & & & 2437 \\
\hline Devolução & 642 & 195 & 224 & 31 & 99 & & & & 1191 \\
\hline Doação & 717 & 400 & 163 & & & & & & 1280 \\
\hline \multicolumn{10}{|c|}{ JUNHO } \\
\hline & Central & 108 Sul & Guariroba & $\begin{array}{l}\text { Ceilândia } \\
\text { Sul }\end{array}$ & $\begin{array}{l}\text { Ceilândia } \\
\text { Norte }\end{array}$ & $\begin{array}{l}\text { Praça do } \\
\text { Relógio }\end{array}$ & $\begin{array}{l}\text { Águas } \\
\text { Claras }\end{array}$ & Samambaia & Total \\
\hline Empréstimo & 1582 & 251 & 128 & 161 & 126 & 446 & 154 & & 2848 \\
\hline Devolução & 639 & 185 & 68 & 135 & 67 & 110 & 49 & & 1253 \\
\hline Doação & 1669 & 482 & 235 & 117 & 182 & 291 & & & 2976 \\
\hline \multicolumn{10}{|c|}{ JULHO } \\
\hline & Central & 108 Sul & Guariroba & $\begin{array}{l}\text { Ceilândia } \\
\text { Sul }\end{array}$ & $\begin{array}{l}\text { Ceilândia } \\
\text { Norte }\end{array}$ & $\begin{array}{l}\text { Praça do } \\
\text { Relógio }\end{array}$ & $\begin{array}{l}\text { Águas } \\
\text { Claras }\end{array}$ & Samambaia & Total \\
\hline Empréstimo & 1788 & 100 & 161 & 152 & 160 & 168 & 192 & & 2721 \\
\hline Devolução & 630 & 96 & 125 & 78 & 106 & 99 & 106 & & 1240 \\
\hline Doação & 1669 & & 80 & 1200 & 430 & 520 & 775 & & 4674 \\
\hline \multicolumn{10}{|c|}{ AGOSTO } \\
\hline & Central & $108 \mathrm{Sul}$ & Guariroba & $\begin{array}{l}\text { Ceilândia } \\
\text { Sul }\end{array}$ & $\begin{array}{l}\text { Ceilândia } \\
\text { Norte }\end{array}$ & $\begin{array}{l}\text { Praça do } \\
\text { Relógio }\end{array}$ & $\begin{array}{l}\text { Águas } \\
\text { Claras }\end{array}$ & Samambaia & Total \\
\hline Empréstimo & 1263 & 107 & 98 & 135 & 134 & 249 & 208 & 309 & 2503 \\
\hline Devolução & 555 & 41 & 31 & 102 & 116 & 134 & 123 & 223 & 1325 \\
\hline Doação & 1025 & 520 & 80 & 600 & 450 & 1200 & 900 & 280 & 5055 \\
\hline \multicolumn{10}{|c|}{ SETEMBRO } \\
\hline & Central & $108 \mathrm{Sul}$ & Guariroba & $\begin{array}{l}\text { Ceilândia } \\
\text { Sul }\end{array}$ & $\begin{array}{l}\text { Ceilândia } \\
\text { Norte }\end{array}$ & $\begin{array}{l}\text { Praça do } \\
\text { Relógio }\end{array}$ & $\begin{array}{l}\text { Águas } \\
\text { Claras }\end{array}$ & Samambaia & Total \\
\hline Empréstimo & 1290 & 232 & 101 & 86 & 150 & 320 & 147 & 157 & 2483 \\
\hline Devolução & 532 & 46 & 31 & 48 & 75 & 186 & 69 & 134 & 1121 \\
\hline Doação & 1000 & 600 & 120 & 250 & 500 & 300 & 200 & 150 & 3120 \\
\hline
\end{tabular}




\begin{tabular}{|c|c|c|c|c|c|c|c|c|c|c|}
\hline \multicolumn{11}{|c|}{ OUTUBRO } \\
\hline & Central & $\begin{array}{l}108 \\
\text { Sul }\end{array}$ & Guariroba & $\begin{array}{l}\text { Ceilândia } \\
\text { Sul }\end{array}$ & $\begin{array}{l}\text { Ceilândia } \\
\text { Norte }\end{array}$ & $\begin{array}{l}\text { Praça do } \\
\text { Relógio }\end{array}$ & $\begin{array}{l}\text { Águas } \\
\text { Claras }\end{array}$ & Samambaia & Guará & Total \\
\hline Empréstimo & 1167 & 132 & 42 & 78 & 68 & 373 & 129 & 152 & 25 & 2166 \\
\hline Devolução & 597 & 128 & 28 & 51 & 41 & 161 & 106 & 103 & & 1215 \\
\hline Doação & 2170 & 500 & 120 & 150 & 300 & 400 & 250 & 400 & & 4290 \\
\hline \multicolumn{11}{|c|}{ NOVEMBRO } \\
\hline & Central & $\begin{array}{l}108 \\
\text { Sul }\end{array}$ & Guariroba & $\begin{array}{l}\text { Ceilândia } \\
\text { Sul }\end{array}$ & \begin{tabular}{c|} 
Ceilândia \\
Norte
\end{tabular} & $\begin{array}{c}\text { Praça do } \\
\text { Relógio }\end{array}$ & $\begin{array}{l}\text { Águas } \\
\text { Claras }\end{array}$ & Samambaia & Guará & Total \\
\hline Empréstimo & 268 & 134 & 71 & 32 & 94 & 226 & 20 & 150 & 404 & 1399 \\
\hline Devolução & 51 & 46 & 27 & 19 & 17 & 115 & 69 & 101 & 116 & 561 \\
\hline Doação & 52 & 31 & 10 & 54 & 130 & 190 & 128 & 57 & 42 & 694 \\
\hline \multicolumn{11}{|c|}{ DEZEMBRO } \\
\hline & Central & $\begin{array}{l}108 \\
\text { Sul }\end{array}$ & Guariroba & $\begin{array}{l}\text { Ceilândia } \\
\text { Sul }\end{array}$ & $\begin{array}{l}\text { Ceilândia } \\
\text { Norte }\end{array}$ & $\begin{array}{l}\text { Praça do } \\
\text { Relógio }\end{array}$ & $\begin{array}{l}\text { Águas } \\
\text { Claras }\end{array}$ & Samambaia & Guará & Total \\
\hline Empréstimo & 366 & 106 & 71 & 42 & 120 & 141 & 240 & 215 & 101 & 1402 \\
\hline Devolução & 147 & 52 & 32 & 13 & 18 & 134 & 88 & 98 & 60 & 642 \\
\hline Doação & 280 & & 28 & 82 & 90 & 85 & 270 & 90 & 50 & 975 \\
\hline
\end{tabular}

Tabela 2: Estatísticas de uso do Conte esta História 2009

\begin{tabular}{|c|c|c|c|c|c|c|c|c|c|c|}
\hline \multicolumn{11}{|c|}{ JANEIRO } \\
\hline & Central & $\begin{array}{l}108 \\
\text { Sul }\end{array}$ & Guariroba & $\begin{array}{l}\text { Ceilândia } \\
\text { Sul }\end{array}$ & $\begin{array}{l}\text { Ceilândia } \\
\text { Norte }\end{array}$ & $\begin{array}{l}\text { Praça do } \\
\text { Relógio }\end{array}$ & $\begin{array}{l}\text { Águas } \\
\text { Claras }\end{array}$ & Samambaia & Guará & Total \\
\hline Empréstimo & 406 & 198 & 83 & 92 & 80 & 227 & 243 & 150 & 251 & 1730 \\
\hline Devolução & 161 & 44 & 15 & 41 & 19 & 86 & 78 & 103 & 157 & 704 \\
\hline Doação & 850 & 680 & 200 & 300 & 310 & 720 & 400 & 535 & 520 & 4515 \\
\hline \multicolumn{11}{|c|}{ FEVEREIRO } \\
\hline & Central & $\begin{array}{l}108 \\
\text { Sul }\end{array}$ & Guariroba & $\begin{array}{l}\text { Ceilândia } \\
\text { Sul }\end{array}$ & $\begin{array}{l}\text { Ceilândia } \\
\text { Norte }\end{array}$ & $\begin{array}{l}\text { Praça do } \\
\text { Relógio }\end{array}$ & $\begin{array}{l}\text { Águas } \\
\text { Claras }\end{array}$ & Samambaia & Guará & Total \\
\hline Empréstimo & 500 & 245 & 86 & 119 & 96 & 251 & 214 & 184 & 231 & 1926 \\
\hline Devolução & 142 & 60 & 33 & 34 & 39 & 126 & 72 & 63 & 118 & 687 \\
\hline Doação & 700 & 500 & 450 & 300 & 500 & 650 & 350 & 220 & 430 & 4100 \\
\hline \multicolumn{11}{|c|}{ MARÇO } \\
\hline & Central & $\begin{array}{l}108 \\
\text { Sul }\end{array}$ & Guariroba & $\begin{array}{l}\text { Ceilândia } \\
\text { Sul }\end{array}$ & $\begin{array}{l}\text { Ceilândia } \\
\text { Norte }\end{array}$ & $\begin{array}{l}\text { Praça do } \\
\text { Relógio }\end{array}$ & $\begin{array}{l}\text { Águas } \\
\text { Claras }\end{array}$ & Samambaia & Guará & Total \\
\hline Empréstimo & 459 & 98 & 88 & 80 & 131 & 170 & 139 & 189 & 194 & 1548 \\
\hline Devolução & 166 & 48 & 37 & 57 & 15 & 84 & 79 & 74 & 83 & 643 \\
\hline Doação & 800 & 600 & 295 & 570 & 380 & 430 & 370 & 600 & 490 & 4535 \\
\hline \multicolumn{11}{|c|}{ ABRIL } \\
\hline & Central & $\begin{array}{l}108 \\
\text { Sul }\end{array}$ & Guariroba & $\begin{array}{l}\text { Ceilândia } \\
\text { Sul }\end{array}$ & $\begin{array}{l}\text { Ceilândia } \\
\text { Norte }\end{array}$ & $\begin{array}{l}\text { Praça do } \\
\text { Relógio }\end{array}$ & $\begin{array}{l}\text { Águas } \\
\text { Claras }\end{array}$ & Samambaia & Guará & Total \\
\hline Empréstimo & 520 & 158 & 98 & 120 & 235 & 210 & 250 & 298 & 265 & 2154 \\
\hline Devolução & 356 & 109 & 56 & 69 & 158 & 91 & 189 & 287 & 245 & 1560 \\
\hline Doação & 1200 & 800 & 400 & 600 & 560 & 700 & 650 & 520 & 480 & 5910 \\
\hline
\end{tabular}

Os dados mostram que há $41 \%$ de devolução e que as doações só vêem crescendo. No começo do projeto havia em média duas ligações por semana para a Secretaria de Cultura buscar doações em domicílios. Hoje, este número 
cresceu para 20 ligações por semana, o que às vezes é difícil de buscar, pela quantidade de funcionários trabalhando no projeto.

\subsubsection{Perfil dos Usuários}

Foi realizado um Estudo de Usuários para identificar o perfil e a satisfação dos usuários que conhecem o projeto Conte esta História - Mala do Livro.

\section{Universo e Amostra}

O universo da pesquisa abrange os usuários do transporte Metrô, que estejam nas estações, em trânsito, utilizando o serviço.

A amostra inclui somente os passageiros que conhecem o Projeto.

Foi aplicado um questionário, com 14 itens, junto aos usuários do Metrô, entre os dias 28 de maio a 03 de junho, nas Estações Ceilândia Sul, Praça do Relógio, Águas Claras e Estação 114 Sul.

A amostra da pesquisa foi de 100 pessoas, escolhidas aleatoriamente, e os dados foram processados pelo Windows Excel 2007.

A análise dos dados é apresentada a partir das questões respondidas:

\section{Usuários que conhecem o projeto}

- Dentre os 100 entrevistados, a maioria (70,59\%) conhece o projeto enquanto $29,41 \%$ não o conhece, conforme Figura 25 :

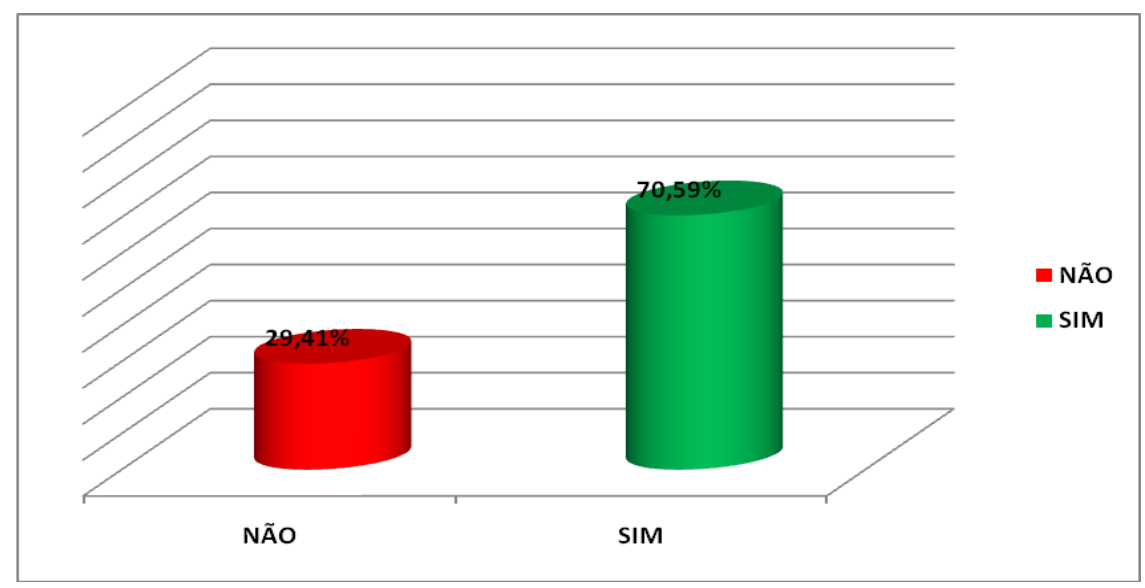

Figura 25: Usuários que conhecem o projeto 
Sexo

- Entre os usuários que conhecem o projeto Conte esta História Mala do Livro, 50,72\% são mulheres e 49,28\% são homens, conforme Figura 26:

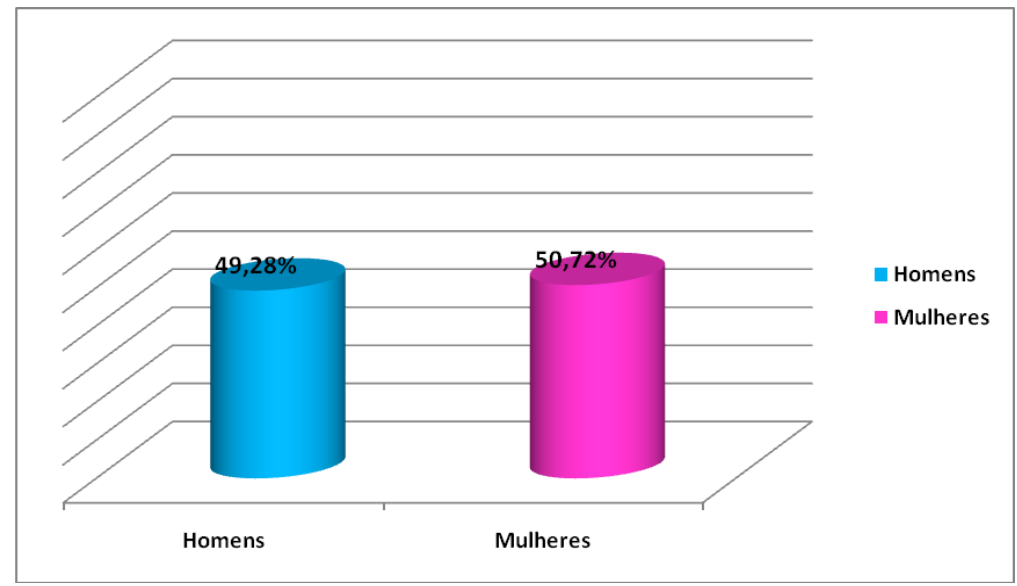

Figura 26: Gênero da amostra

\section{Local onde reside}

- A maioria dos usuários (85,51\%) reside em cidades satélites, $11,59 \%$ mora em Brasília e os demais (2,90\%) no entorno do Distrito Federal, conforme Figura 27:

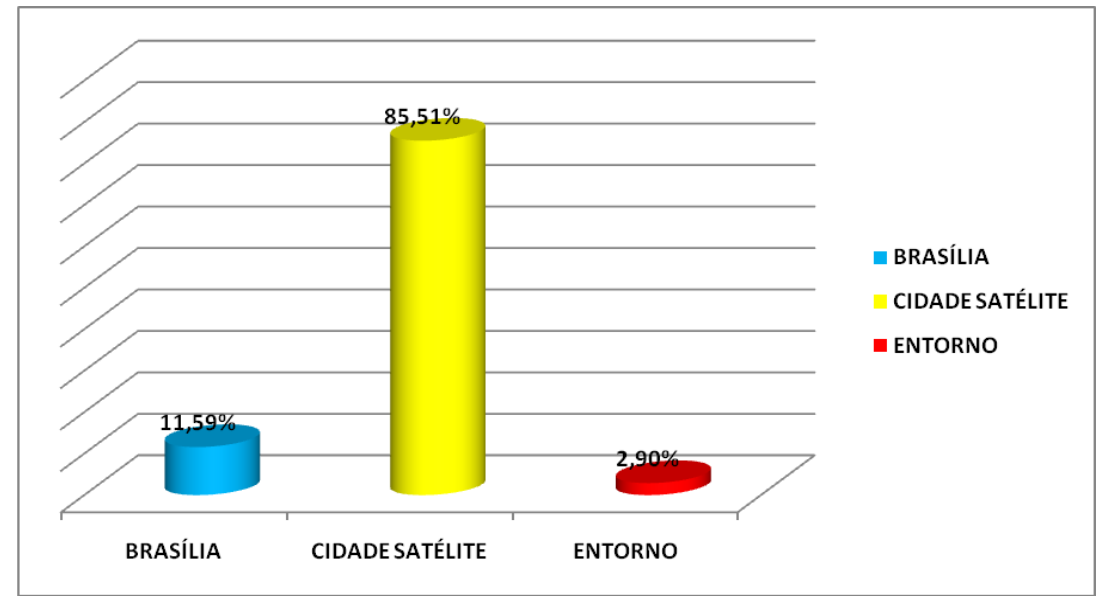

Figura 27: Local onde reside 


\section{Faixa Etária}

- Com relação à faixa etária dos usuários, o projeto tem um público bastante variado. Grande parte tem idade entre 19 a 25 anos (31,88\%), seguido do público de 26 a 35 anos $(26,09 \%)$ e de 13 a 18 anos $(21,74 \%)$. A faixa etária entre 36 a 60 anos somam $17,39 \%$ dos usuários, enquanto que a de 8 a 12 anos são apenas $2,90 \%$ do total, de acordo com a Figura 28 :

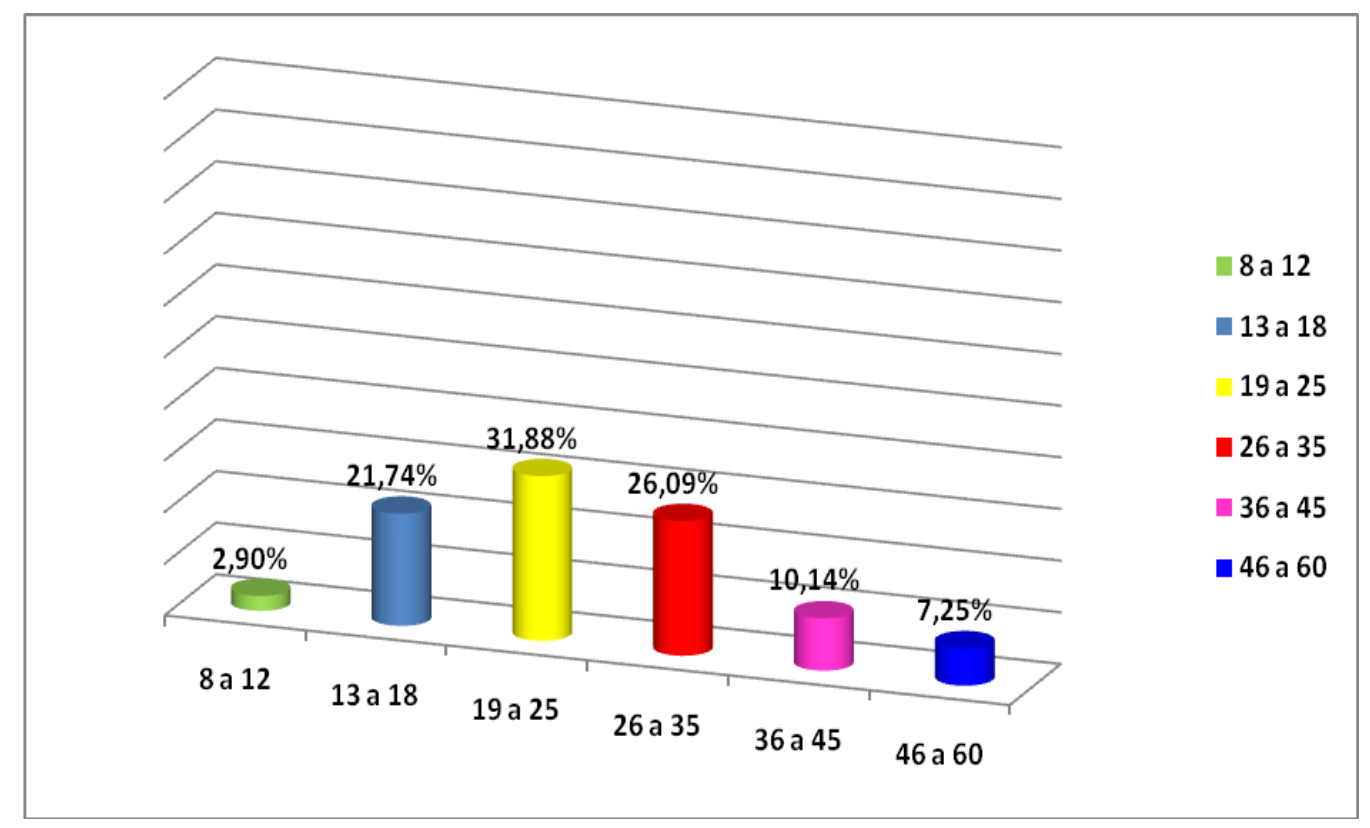

Figura 28: Faixa Etária

\section{Nível de Escolaridade}

- Quanto ao nível de escolaridade, $36,23 \%$ da amostra tem ensino médio completo, $26,09 \%$ tem ensino superior incompleto, $21,74 \%$ não terminou o ensino médio, 10,14\% tem ensino fundamental, e apenas $5,80 \%$ da amostra tem ensino superior completo, conforme Figura 29: 


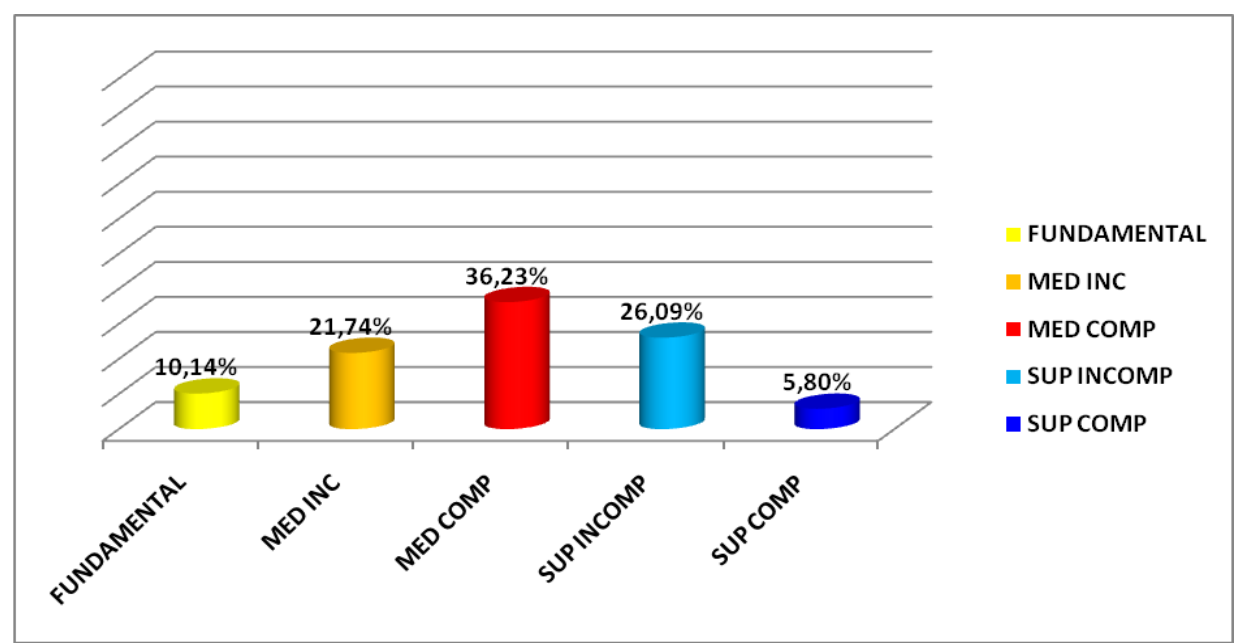

Figura 29: Nível de Escolaridade

\section{Ocupação}

- Verificou-se que a maioria dos usuários são estudantes $(31,88 \%)$, seguidos daqueles que trabalham na iniciativa privada (28,99\%). Os funcionários públicos compõem 18,84\% da amostra, e 14,49\% trabalham como autônomos. Por fim, 5,8\% dos indivíduos são do lar ou estão desempregados no momento, conforme Figura 30:

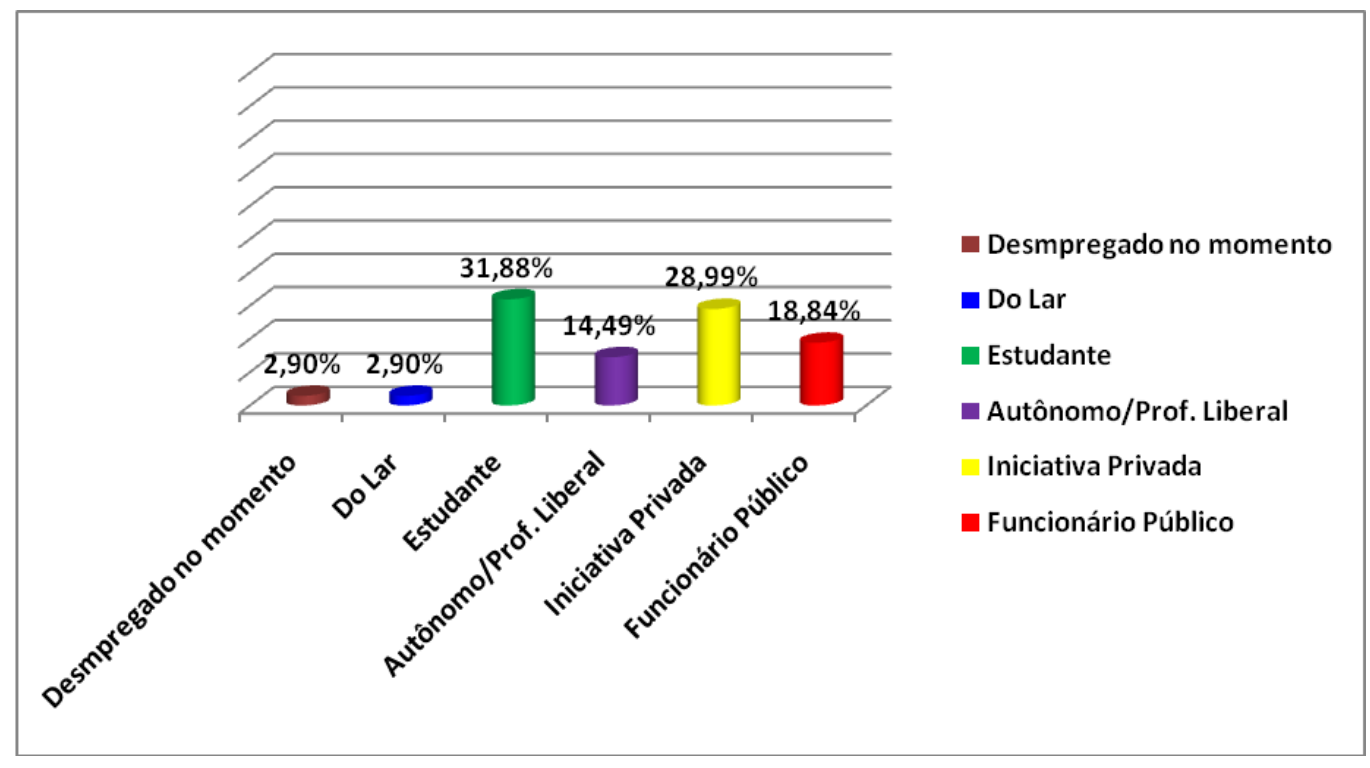

Figura 30: Ocupação 


\section{Renda Familiar Mensal}

- Do ponto de vista da renda familiar, a Figura 31 indica que a maioria (50\%) ganha de $R \$ 1.000,00$ a $3.500,00$ reais por mês. Os que ganham até 500,00 somam $19,12 \%$ da amostra, 17,65\% ganham de 500,00 a 1.000,00 e somente $13,24 \%$ ganham acima de 3.500,00 por mês.

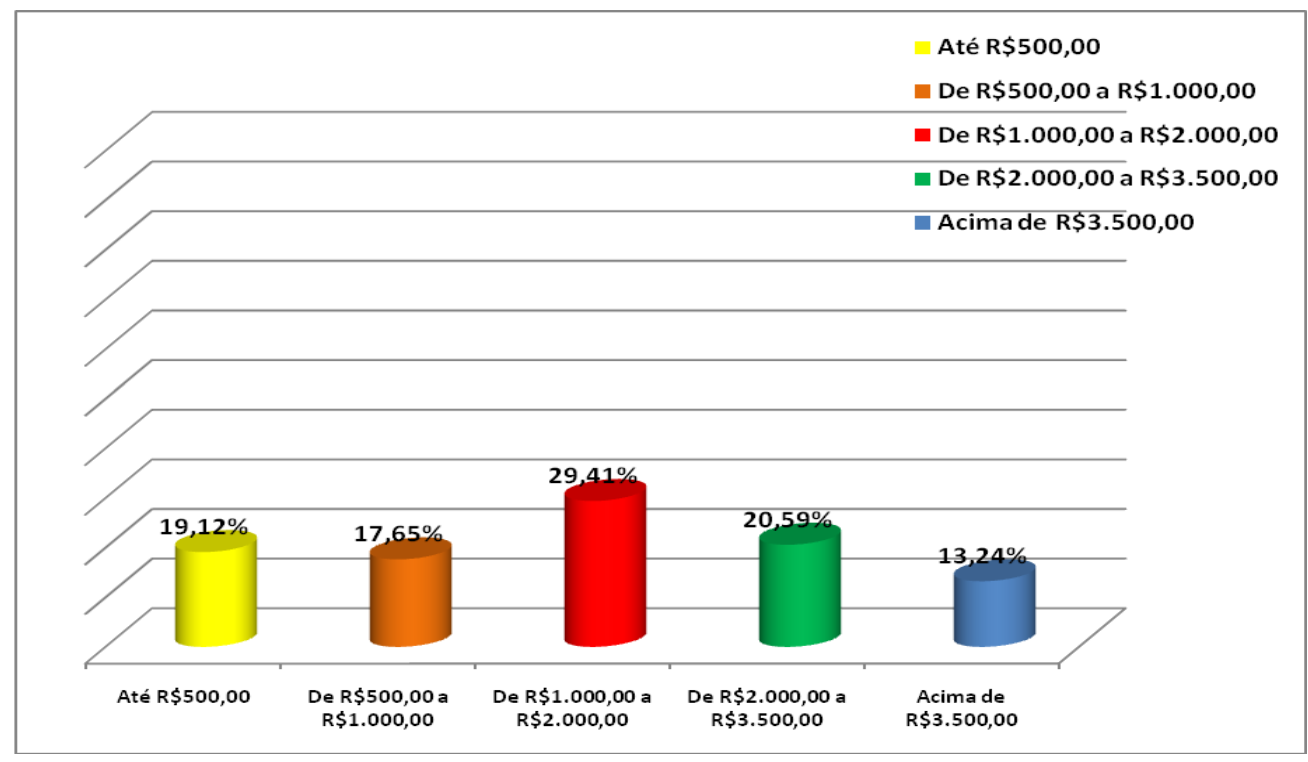

Figura 31: Renda Familiar Mensal

\section{Freqüência às Bibliotecas}

- Dos usuários que conhecem o projeto, 57,97\% freqüentam raramente outras bibliotecas. Os que "freqüentemente" estão em bibliotecas representam 33,33\% dos usuários, enquanto $8,70 \%$ nunca vão a outras bibliotecas, segundo Figura 32:

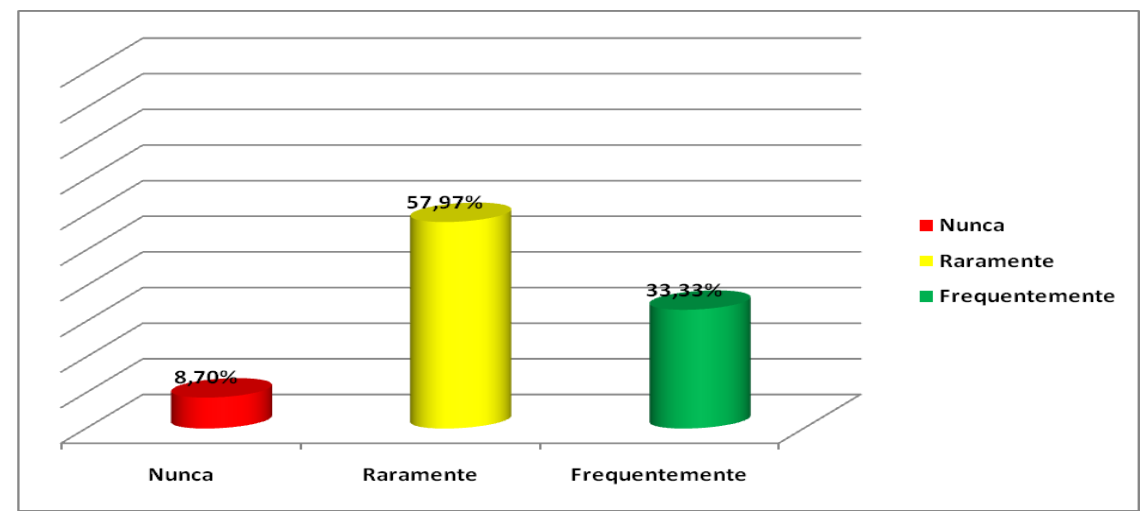

Figura 32: Freqüência às Bibliotecas 


\section{Quantidade de livros lidos por ano}

- A Figura 33 indica que $4,41 \%$ das pessoas conhecem o Projeto, mas não lêem nenhum livro por ano. Os que lêem de 1 a 7 livros somam $64,70 \%$ da amostra, seguida de $19,12 \%$ que lêem mais de 10 livros e de $11,76 \%$ que lêem de 8 a 10 livros por ano:

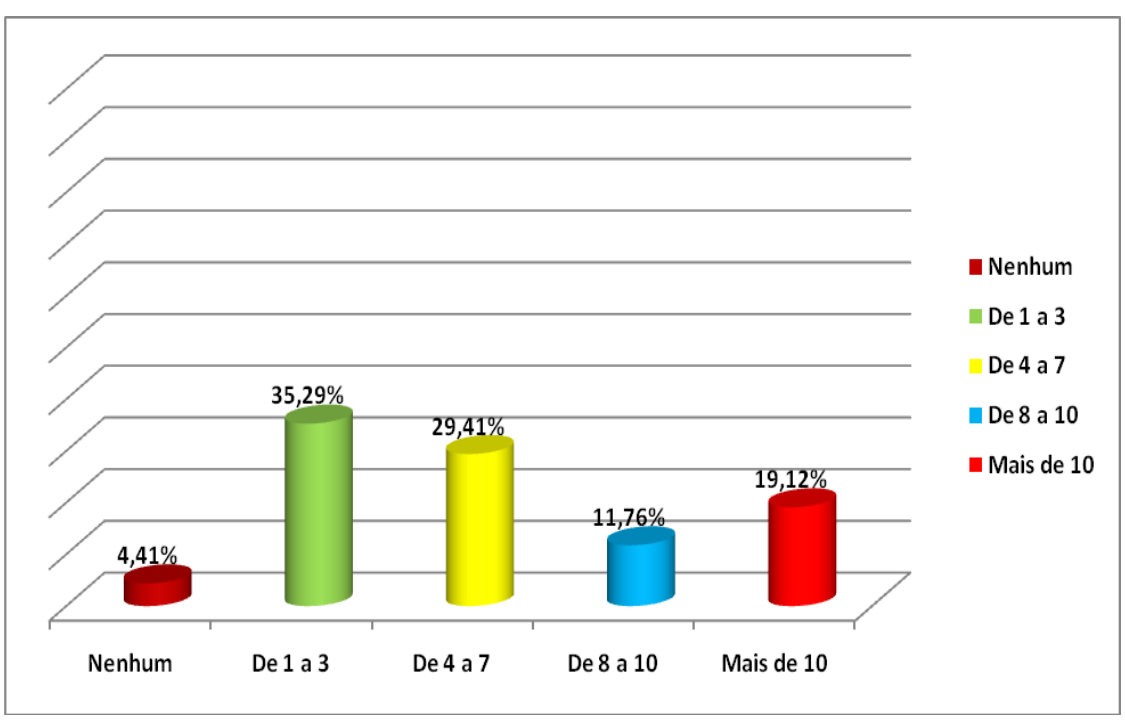

Figura 33: Quantidade de livros lidos por ano

\section{Empréstimo de Livros}

- Das pessoas que conhecem o projeto, 43,48\% já retiraram algum livro, enquanto $56,52 \%$ nunca fizeram empréstimo de livros do Projeto Conte esta História, conforme Figura 34:

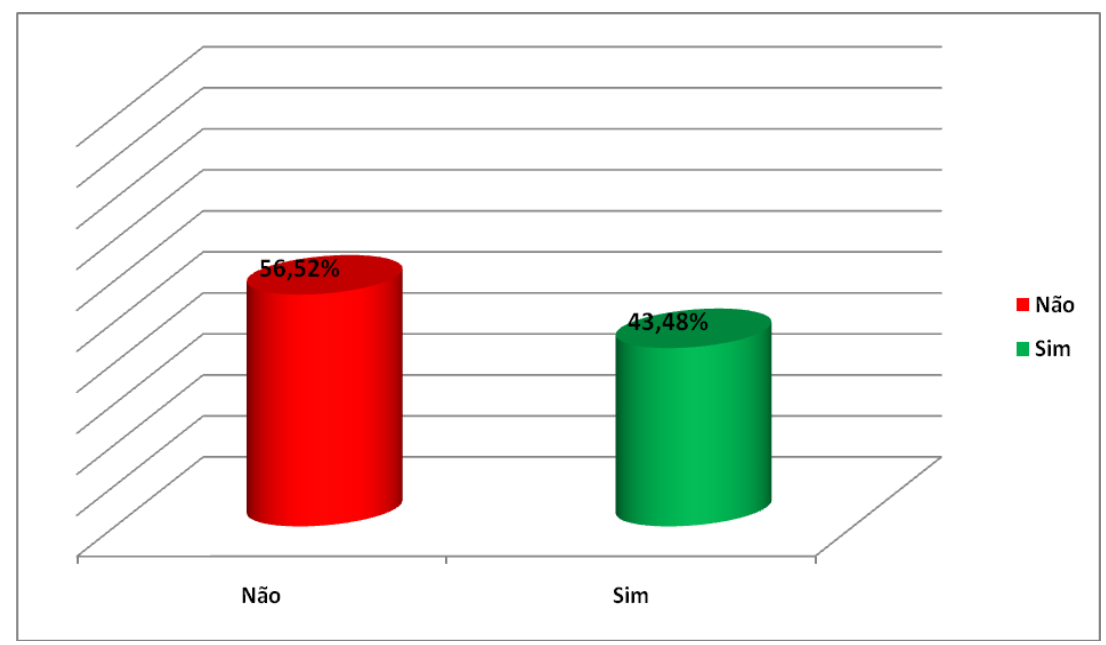

Figura 34: Empréstimo de Livros 


\section{Quantidade de livros emprestados}

- Dos entrevistados que já retiraram livros, a maioria $(51,61 \%)$ retirou de 2 a 4 livros. Os que retiraram "mais de 7", representam 25,81\%; $6,45 \%$ retiraram de 5 a 7 livros e os que retiraram apenas 1 livro são $16,13 \%$ da amostra, conforme Figura 35 :

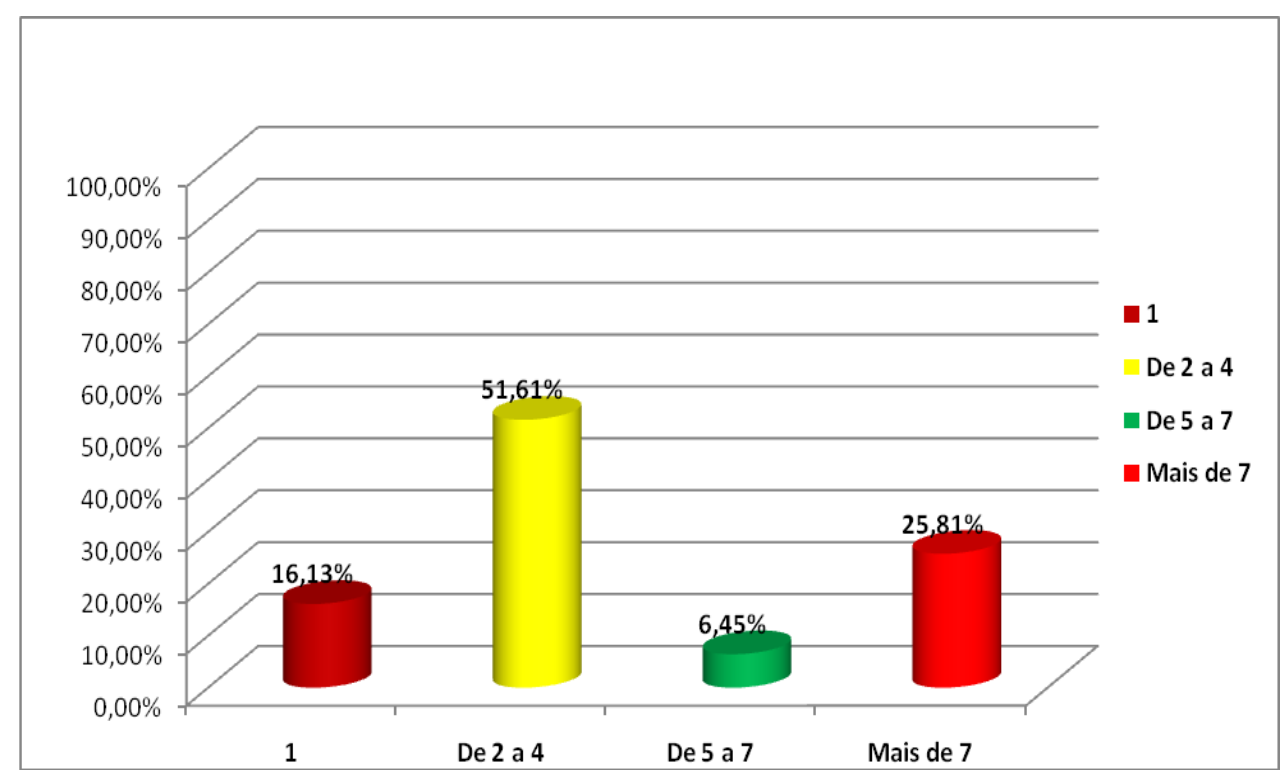

Figura 35: Quantidade de Livros emprestados

\section{Dificuldades para utilização da Biblioteca}

- Foi perguntado aos usuários qual era a maior dificuldade que tinham ao utilizar o Projeto Conte esta História (Biblioteca do Metrô). Conforme a Figura 36, o item mais assinalado foi quanto à variedade de livros $(33,33 \%)$, seguido do tempo gasto para encontrar o livro desejado (27,27\%). Quanto ao ambiente para a consulta aos livros $13,64 \%$ da amostra considerou esta a maior dificuldade, e 25,76\% não opinaram sobre o assunto. Também foram citados outros motivos, principalmente a falta de cadeiras no estande seguida da falta de tempo para parar e retirar o livro desejado, de acordo com a Figura 36: 


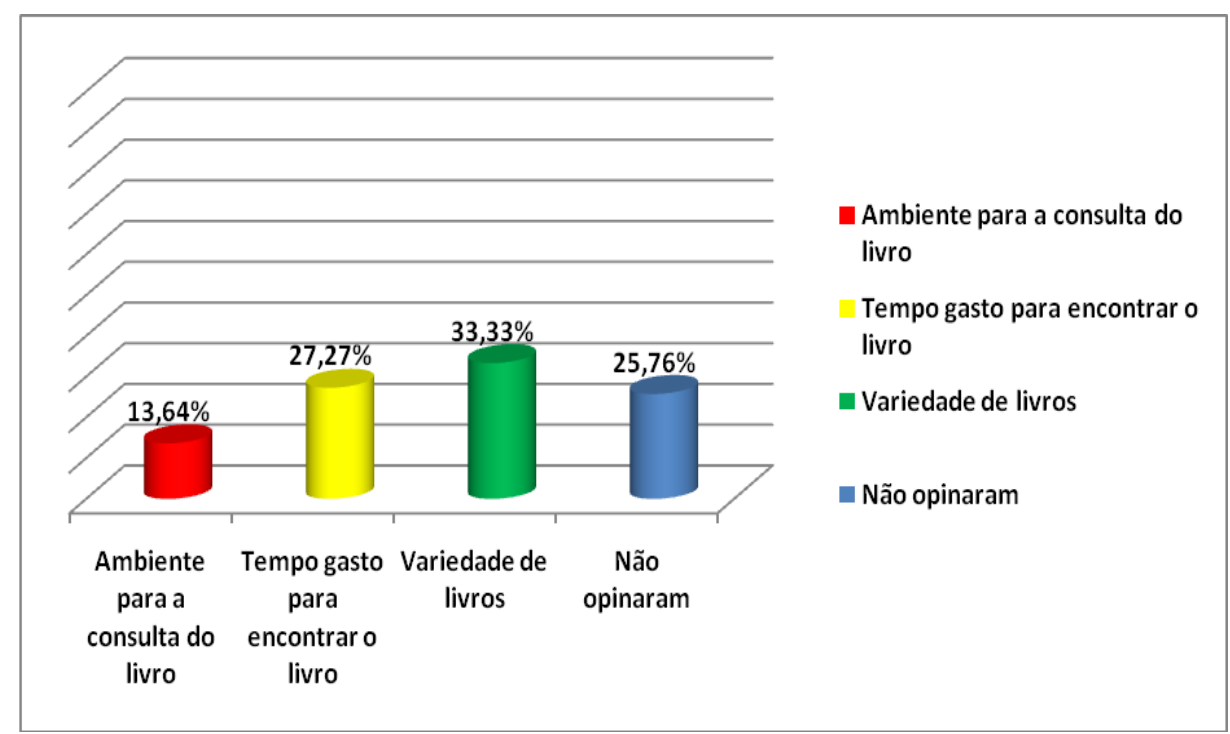

Figura 36: Dificuldade ao usar o Projeto

Entre as perguntas do questionário, foi perguntado aos usuários se havia algum material que ele procura no Projeto Conte esta História e não encontra. As respostas mais freqüentes foram:

- Livros de nível superior.

- Livros de informática.

- Livros de História.

- Livros de fotografia.

- Literatura do vestibular.

- Livros para concurso.

- Literatura atual/ moderna.

- Literatura brasileira.

Com relação às sugestões que dariam ao projeto, as mais citadas foram:

- Espaço maior e mais confortável, adequado para leitura, com bancos.

- Maior variedade de livros.

- Livros mais interessantes e de autores famosos.

- Organização do acervo por assunto.

- Divulgação do projeto. 
- Oficinas de leitura e organização de saraus.

- Funcionário do Projeto, em cada estande, para atender e dar informações.

- Ampliação do Projeto para todas as estações.

- Inclusão de gibis no acervo.

\subsection{ESTRATÉGIAS PARA MELHORIA DO PROJETO}

A partir das respostas do questionário aplicado e da situação do Projeto, buscou-se levantar as deficiências do Conte esta História - Mala do Livro, bem como as necessidades dos seus usuários. Diante dos resultados, são sugeridas as seguintes estratégias para melhor e maior utilização do projeto:

- Divulgação do projeto dentro do trem e nas estações, por meio de cartazes, banners, panfletos que contenham informações sobre a biblioteca do Metrô (Conte esta História) e como utilizá-la.

- Treinar os funcionários do Metrô para que eles possam dar informações de funcionamento do projeto aos usuários, tendo em vista a impossibilidade atual de haver um funcionário permanente nos estandes.

- O estande funcionar também como um local de orientação ao público, com informações relativas a mercado de trabalho, direito do consumidor, meios de obtenção de documentos e outras.

- Parceria com a iniciativa privada para assinatura dos jornais diários do DF.

- Palestras sobre os principais assuntos da atualidade.

- Atividades culturais e de lazer como saraus, conversas com escritores, apresentações musicais, teatrais e outros. 


\section{CONCLUSÃo}

A prática da leitura é um importante instrumento para o exercício da cidadania e da participação social. Com o intuito inicial de estimular essa prática, estão surgindo diversas formas de incentivo à leitura em nosso país, por parte do governo e de ONGs, que tentam amenizar a falta de bibliotecas públicas capazes de suprir essa carência.

Esta monografia possibilitou um estudo aprofundado do Projeto "Conte esta História - Mala do Livro", projeto promissor do Distrito Federal, onde um meio de transporte é utilizado como um meio de disseminação de informação e conhecimento.

Pretendeu-se mostrar com este trabalho a importância de iniciativas como o "Conte esta História" para o desenvolvimento de toda uma sociedade, pois com ele, pessoas que nunca tiveram acesso ao livro têm a oportunidade de ler, sem nenhum tipo de obstáculo. Mostrou também quais são as deficiências do projeto juntamente com as sugestões de melhorias, para facilitar e expandir os seus serviços.

No Brasil, onde historicamente a literatura nunca foi considerada um item importante para o desenvolvimento do país, onde a cultura não é valorizada como deveria, projetos como esse são sempre bem-vindos e essenciais para fomentar o hábito da leitura e servem como exemplo para quebrar o paradigma de que os brasileiros não gostam de ler.

As Bibliotecas do "Conte esta História" são capazes de propiciar à comunidade oportunidades de crescimento e desenvolvimento social. Sendo o Metrô - DF um local de grande fluxo, é um espaço privilegiado para o processo de disseminação de informação. Constitui-se em um dos caminhos ideais para proporcionar à população acesso ao livro, cultura, cidadania e combater a exclusão social, ao contribuir na formação de indivíduos culturalmente íntegros e conscientes de suas capacidades. 


\section{REFERÊNCIAS}

ALMEIDA JÚNIOR, Oswaldo Francisco de.. Biblioteca Pública: avaliação de serviços. Londrina, PR: Ed Universidade Estadual de Maringá, 2003. 288 p.

ALMEIDA, Maria Christina Barbosa de. Planejamento de bibliotecas e serviços de informação. Brasília: Briquet de Lemos/Livro, 2000.

AMORIM, Galeno (Coord.) Políticas públicas do livro e leitura. Brasília: OEl; São Paulo: Cultura Acadêmica, 2006. 64 p.

ARAÚJO, Eliany Alvarenga de. A palavra e o silêncio: biblioteca pública e o estado autoritário no Brasil. João Pessoa: Ed Univ., 2002. 99 p.

ASSOCIAÇÃO BRASILEIRA DE NORMAS TÉCNICAS. NBR 6023: informação e documentação: referência: elaboração, 2002.

NBR 10520: informação e documentação: citações em documentos:

apresentação. Rio de Janeiro, 2002.

BAPTISTA, Myrian Veras. Planejamento: introdução à metologia do planejamento social. 4. ed. São Paulo: Moraes, 1981.

BARATIN, Marc; JACOB, Christian. O poder das bibliotecas: a memória dos livros no Ocidente. 2. ed. Rio de Janeiro: UFRJ, 2006. 351p.

BARRETO, Aldo A. A questão da informação. São Paulo em Perspectiva, v.8, n.4, 1994.

BARRETO, Ângela Maria. et al. Bibliotecas Públicas e Telecentros: ambientes democráticos e alternativos para a Inclusão Social. Ciência da Informação, Brasília, v. 37, n. 1, p. 27-36, jan./abr. 2008.

BARROS, D. S.; SAORIM, R. N. S.; RAMALHO, F. A. Necessidades Informacionais e comportamento de busca da Câmara Municipal de João Pessoa- Paraíba. Informação e Sociedade: João Pessoa, v. 8, n. 3, p. 171-184, set/dez. 2008.

Biblioteca Nacional (Brasil). A biblioteca pública: administração, organização, serviços. Porto Alegre: L\&PM Editores, 1999. 118 p. 
BORTOLOM, M. A. et al. Levantamento das características culturais de leitura da comunidade acadêmica do curso de biblioteconomia da Universidade Federal de Santa Catarina. Revista ACB, Florianópolis v. 3, n. 3, p. 113-123. 1998.

BRAMBILA, Ednéa Zandonadi. Biblioteca pública e o resgate informacional da cultura territorializada: o caso da biblioteca pública estadual Levy Cúrcio da Rocha. 2005. 177 f. Dissertação (mestrado) - Pontifícia Universidade Católica de Campinas.

CARVALHO, I.; KANISKI, A.. A Sociedade do Conhecimento e o acesso à informação: para que e para quem. Ciência da Informação, Brasília, v. 29, n. 3, p. 33-39, set/dez. 2000.

CHIAVENATO, Idalberto. Administração: teoria, processo e prática. 2. ed. São Paulo: Makron Books, 1994.

FERREIRA, Sueli Mara S. P. Estudo de necessidades de informação: dos paradigmas tradicionais à abordagem sense-making. Porto Alegre : ABEBD, n.2, 1997.

FISCHMANN, A. A.; ALMEIDA, M. I. R. de. Planejamento estratégico na prática. 2. ed. São Paulo: Atlas, 1991.

FIGUEIREDO, Nice Menezes de. Aspectos especiais de estudos de usuários. Ciência da informação, Brasília, v. 12, n. 2, p. 43-57, jul/dez. 1983.

FREIRE, Paulo. A importância do ato de ler: em três artigos que se completam. 47. ed. São Paulo: Cortez, 2006. 87 p.

FREITAS, Maria Terezinha N. ET AL.. Educação pela leitura: uma experiência . Perspectiva, Florianópolis, v. 3, n. 7, p. 26-40, jul/dez. 1986.

FURLAN, José Davi. Como elaborar e implementar o planejamento estratégico de sistemas de informação. São Paulo: Makron/McGraw, 1991.

HOLANDA, Nilson. Planejamento e projetos. Fortaleza: Universidade Federal do Ceará, 1982. 
LAJOLO, Marisa; ZILBERMAN, Regina. A leitura rarefeita: livro e literatura no Brasil. São Paulo: Brasiliense, 1991. 177 p.

LE COADIC, Yves-francois. Ciência da informação. Brasília: Briquet De Lemos/ Livros, 1996. $119 \mathrm{p}$.

MACIEL. Alba Costa. Planejamento de bibliotecas. Niterói: EDUFF, 1993.

MACIEL, A. C.; MENDONÇA, M. A. R. Bibliotecas como organizações. 1. ed. rev. Rio de Janeiro: Interciência, 2006.

MARTINS, Maria Helena. O que é leitura. São Paulo: Brasiliense, 1994. (Coleção Primeiros Passos, 74).

MARTINS, Myriam Gusmão de. Planejamento bibliotecário. São Paulo: Pioneira, 1980.

MASUDA, Yoneji. A Sociedade da Informação - como sociedade pós-industrial. Rio de Janeiro : Ed. Rio, 1980.

MAXIMIANO, A. C. A. Introdução à administração. 5. ed. São Paulo: Atlas, 2000.

MILANESI, Luís. O que é biblioteca. 1. ed. São Paulo: Brasiliense, 1983. (Coleção primeiros passos; 94).

. Biblioteca. São Paulo: Ateliê Editorial, 2002.

. A casa da invenção: biblioteca, centro de cultura. 4. ed. Cotia: Ateliê, 2003.

MIRANDA, Antônio Lisboa Carvalho de. Informação para o desenvolvimento: o planejamento bibliotecário no Brasil. Brasília: Editora Universidade de Brasília, 1977.

Sociedade da Informação: globalização, identidade cultural e conteúdos. Ciência da informação, Brasília, v. 29, n. 2, p. 78-88, maio/ago. 2000. 
OLIVEIRA, B. T. de; SIENNA, M. M. Leitura pública: um estudo de caso na biblioteca pública do Paraná, 2008. Disponível em: http://www.repositorio.seap.pr.gov.br/arquivos/File/gestao_de_politicas_publica s_no_parana_coletanea_de_estudos/cap_1_educacao/capitulo_1_3.pdf. Acesso em: 30 jan. 2009.

PLANO NACIONAL DO LIVRO E LEITURA. Biblioteca Domiciliar Neusa Dourado: Programa Mala do Livro. Disponível em: www.vivaleitura.com.br. Acesso em 2 maio 2009.

ROBREDO, Jaime. Informação e transformação. Brasília: Abdf, 1984. 97 p.

SANTOS, M. V. M. dos. A leitura como prática cotidiana e motivacional: da infância ao crescimento intelectual e discernimento crítico. Revista $A C B$ : Biblioteconomia em Santa Catarina, Florianópolis, v.11, n. 1, p.29-37, jan./jul., 2006.

SILVA, Ezequiel Theodoro da. Leitura na escola e na biblioteca. 5. ed. Campinas: Papirus, 1995. 115 p.

SANDRONI, Laura C.; MACHADO, Luiz Raul. Ler em casa. In: $A$ criança e o livro. 2. ed. São Paulo: Ática, 1987. p. 18-21.

SUAIDEN, Emir José. Biblioteca pública e informação à comunidade. São Paulo: Global, 1995. 112 p. (Coleção ciência da informação).

A biblioteca pública no contexto da sociedade da informação. Ciência da Informação, Brasília, v. 29, n. 2, p. 52-60, mai./ago. 2000. 
ANEXO

Questionário: Perfil dos usuários do Projeto Conte esta História - Mala do Livro 


\title{
QUESTIONÁRIO
}

1. Sexo:

\section{Projeto Conte Esta História - Mala do Livro}

$\square$ Masculino

2. Onde mora:

$\square$ Brasília

3. Idade:
De 8 a 12 anos
De 13 a 18 anos
De 19 a 25 anos
De 26 a 35 anos
De 36 a 45 anos
De 46 a 60 anos

$\square$ Feminino

Cidade Satélite

Entorno

4. Qual o seu Nível de Escolaridade?
Fundamental
Médio Completo
Médio incompleto
Superior Incompleto
$\square$ Superior Completo

5. Qual a sua ocupação?
$\square$ Desempregado no momento
Estudante
Do Lar

\author{
Autônomo/ Profissional \\ Liberal \\ Funcionário de \\ empresa privada \\ Empresário
}

\section{Acima de 60 anos}

6. Qual a sua Renda Familiar Mensal?
Até $\mathrm{R} \$ 500,00$
$\square$ De $R \$ 1.000,00$ a $R \$$ $2.000,00$
De $R \$ 500,00$ a $R \$$ $1.000,00$
De $R \$ 2.000,00$ a $R \$$ $3.500,00$

Funcionário Público

Aposentado

7. Você costuma ir à Biblioteca?
$\square$ Nunca
Raramente

Freqüentemente

8. Quantos livros em média você lê por ano?
$\square$ Nenhum
$\square \quad$ De 4 a 7
De 1 a 3
De 8 a 10

Acima de $R \$ 3.500,00$

9. Você conhece o projeto Conte Esta História - Mala do Livro (BIBLIOTECA DO METRÔ)? $\square$ Não Sim

10. Você já pegou algum livro do projeto?
$\square$ Não
$\operatorname{Sim}$

11. Quantos?
$\square \quad 1$
5 a 7
2 a 4
Mais de 7

12. Tem algum material que você procura na Biblioteca do Metrô e não encontra?
Não
$\square \operatorname{Sim}$
$\square$ Qual?

13. Qual a sua maior dificuldade ao usar a Biblioteca do Metrô?
Ambiente para a consulta do livro
Tempo gasto para encontrar o livro desejado
$\square \quad$ Variedade de livros

14. Que sugestão você daria para o projeto? 